University of Chicago Law School

Chicago Unbound

Journal Articles

Faculty Scholarship

1975

\title{
Judicial Review of Federal Administrative Action: Quest for the Optimum Forum
}

David P. Currie

Frank I. Goodman

Follow this and additional works at: https://chicagounbound.uchicago.edu/journal_articles

Part of the Law Commons

\section{Recommended Citation}

David P. Currie \& Frank I. Goodman, "Judicial Review of Federal Administrative Action: Quest for the Optimum Forum," 75 Columbia Law Review 1 (1975).

This Article is brought to you for free and open access by the Faculty Scholarship at Chicago Unbound. It has been accepted for inclusion in Journal Articles by an authorized administrator of Chicago Unbound. For more information, please contact unbound@law.uchicago.edu. 


\title{
COLUMBIA LAW REVIEW
}

Vol. 75

JANUARY 1975

No. 1

\section{JUDICIAL REVIEW OF FEDERAL ADMINISTRATIVE ACTION: QUEST FOR THE OPTIMUM FORUM}

\author{
DAVID P. CURRIE* AND FRANK I. GOODMAN**
}

Professors Currie and Goodman present a comprehensive analysis of the variables that must be isolated and weighed in determining the optimum forum for judicial review of administrative action. While the backdrop for this study is the caseload crisis presently confronting the federal courts of appeals, their discussion illuminates the requisites for optimum judicial revieze generally.

Failing to perceive any compelling reason to single out administrative cases for reviez in separate courts, the authors argue against the creation of special administrative appeals courts. Even if such courts were to enjoy broad subject matter jurisdiction over the most demanding aspects of the agency review caseload, countervailing considerations, such as the danger of improper influence on the appointment process and the loss of the judges' generalist perspective, outweigh the perceived benefits of uniformity, expertise and relief for the regional courts of appeals.

As to the optinal forum werthin the present system of district courts and courts of appeals, the authors divide their discussion into three categories of agency action. With respect to formal agency determinations, the authors generally favor direct appellate court review, except where diversion to the district courts in the first instance is necessary to reduce an appellate workload which has grozen to such proportions that it threatens the collegial nature of circuit court decisionmaking; and among two-tier systems, the authors suggest that discretionary appellate review be limited to areas generating a burdensome volume of appeals, involving issues or interests of relative insignificance and not bearing a potential for biased or misguided trial court decisions.

Informal rulemaking, generally involving issues of legal importance which are likely to ultimately reach the courts of appeals in any event, is presumptively appropriate for direct appellate review. Despite the absence of a

* Professor of Law, University of Chicago. A.B., 1957, University of Chicago; L.L.B., 1960, Harvard University.

* Professor of Law, University of Pennsylvania. A.B., 1954; L.L.B., 1959, Harvard University. B.A., 1956, Oxford University. 
trial-type record, the courts of appeals will not have to engage in extensive factfinding, for any factual issues will increasingly be determined on the basis of materials before the agency, and any need for new factual information will be rare and obtainable by methods short of a judicial trial.

In the case of informal adjudication, however, the absence of a formal adjudicative record justifies a presumption in favor of initial district court review. Informal rulemaking is distinguished, for the issues arising from informal adjudication are likely to involve questions of specific fact, there is little guarantee of any meaningful record for review, and a larger proportion of such determinations are relatively unimportant and unlikely to be taken to the courts of appeals. The authors recognize that direct circuit court review may be appropriate if review is limited to reconstruction of the record before the agency and there is therefore no significant factfinding burden.

\section{Table of Contents}

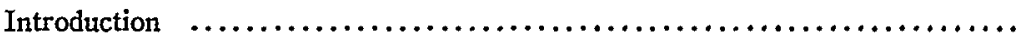

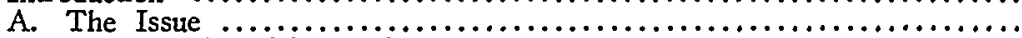

B. Patterns of Judicial Review ................................ 4

I. District Court or Court of Appeals Review: Two-Tier or Single-Tier

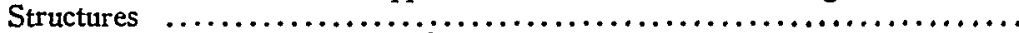

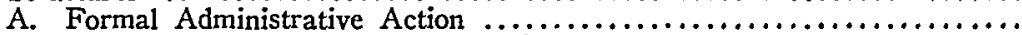

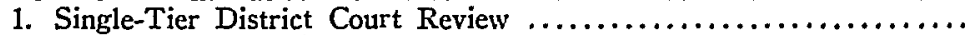

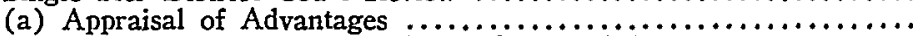

(b) The Superior Characteristics of Courts of Appeals ............

2. Mandatory Two-Tier Review: Appeal as of Right ..................

(a) Two-Tier or Direct Court of Appeals Review .................

3. Discretionary Two-Tier Review: Appeal by Leave ................

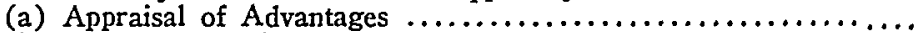

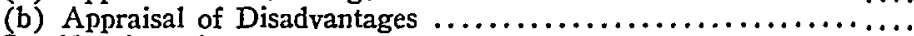

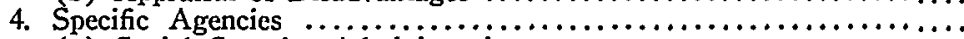

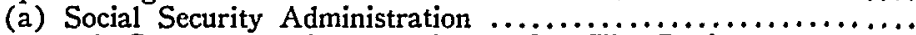

(1) Current Practice: Mandatory Two-Tier Review ............ 23

(2) Appraisal of Direct Court of Appeals Review ........... 24

(3) Appraisal of Discretionary Two-Tier Review ............. 25

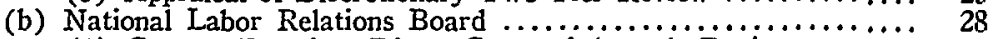

(1) Current Practice: Direct Court of Appeals Review ......... 28

(2) Appraisal of Mandatory Two-Tier Review ............. 28

(3) Appraisal of Discretionary Two-Tier Review ............. 30

(c) Immigration and Naturalization Service: Deportation Cases ..... 31

(1) Current Practice: Bifurcated Review .................. 31

(2) Appraisal of Two-Tier Review ..................... 34

(d) Department of 'Labor: Longshoremen's Compensation and Black

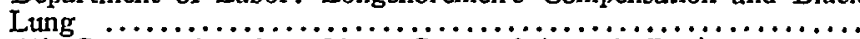

(1) Current Practice: Direct Court of Appeals Review........... 36

(2) Potentially Increasing Caseload Burden: Appraisal of Nced for Two-Tier Review .................................

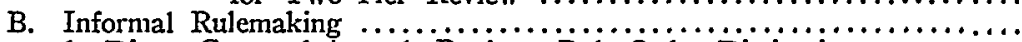

1. Direct Court of Appeals Review: Rule-Order Distinction ..............

2. Appraisal of Need for Appellate Court Factfinding ..................

3. Appraisal of Other Objections ................................

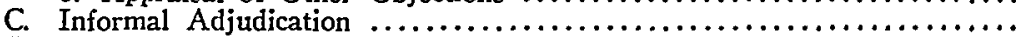

II. Specialized Courts and Exclusive Venue ..................................

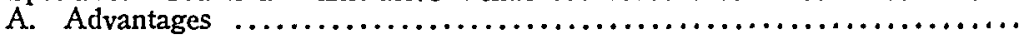

1. Relief for the Regular Courts .................................

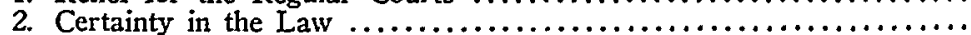

3. Better Understanding ........................................ 67 


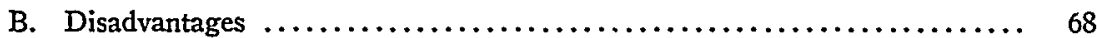

1. Loss of Generalist Perspective .................................. 68

2. Loss of Diverse Views and the Concentration of Power ................, 69

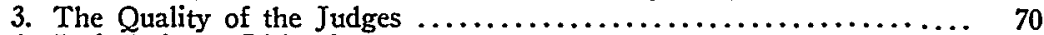

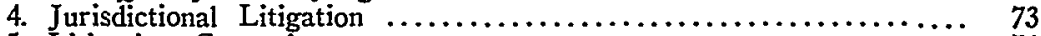

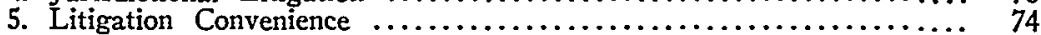

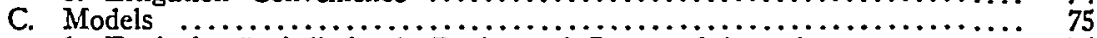

1. Exclusive Jurisdiction in Designated Courts of Appeals ................ 75

2. Exclusive Jurisdiction in Administrative Appeals Courts .............. 75

(a) Subject Matter Jurisdiction ........................... 76

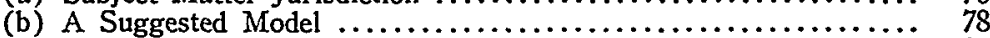

D. Conclusion ............................................... 82

III. Proposals for a National Court of Appeals .......................... 85

\section{INTRODUCTION}

\section{A. The Issue}

The aim of this Article is to explore the considerations that determine which federal administrative actions are best reviewed by the district courts, which by the courts of appeals, ${ }^{* * *}$ and which by separate courts of administrative review.

This study was commissioned jointly by the Administrative Conference of the United States, which has a continuing interest in questions respecting judicial review of agency action, and by the Commission on Revision of the Federal Court Appellate System, which is particularly concerned with the issue as it affects the circuit courts. That Commission, created in response to serious warnings that the courts of appeals are overloaded, has heard how the press of cases has led to heightened use of summary procedures and to the fear that the quality of decision may be impaired. While it is this concern that provides the immediate impetus for the present study, it would be a mistake to view the matter entirely from the standpoint of the courts of appeals. The overriding goal must be to afford adequate and efficient access to the courts generally. At the same time, the condition of all of the courts is a relevant factor in assessing the optimum system of judicial review: A review scheme that looks good on paper may be a disaster if overloaded dockets seriously impair the quality of adjudication.

In fiscal 1974, 1,994 of the 16,436 cases (12 percent) filed in the eleven circuit courts came directly from federal "Boards and Commissions" other than the Tax Court. ${ }^{1}$ Moreover, in the same year the United States or its officers or agencies were parties to over half $(7,334$ of 13,491$)$ of the cases appealed to the circuit courts from the district courts. Many of these were ordinary criminal cases. Even so, and setting aside proprietary and tax cases, it appears that several hundred administrative cases, perhaps nearly a

*a* The United States Court of Appeals will be referred to, interchangeably, as "courts of appeals," "appeals courts," or "circuit courts"; the latter term, though not strictly correct, frequently serves the interests of brevity, euphony, or variety.

1. 1974 REPORT OF THE Director OF THE ADMINISTRATIVE OfFICE OF U.S. Courts, table B3 [hereinafter cited as A.O. REPORT]. 
thousand, reach the circuit courts annually through the district courts. ${ }^{2}$ The number of such cases not appealed beyond the district courts is presumably a good deal higher.

Dean Roger Cramton has identified three dimensions of any inquiry into what constitutes the optimum in institutions for the resolution of controversies: accuracy, efficiency and acceptability. ${ }^{3}$ By accuracy is meant all those considerations that contribute to a high quality of decisionmaking: the qualifications of the deciders, adequate time for deliberation, and so forth. Efficiency reflects the truism that the conditions for quality decisionmaking are not without cost: It is also desirable to avoid undue delay, expense, or the extra litigation that may be prompted by fuzzy jurisdictional lines or by the uncertainty of substantive law. Acceptability embraces the principle that it is important that litigants feel they have been fairly treated. We shall bear these dimensions in mind in exploring the question of optimum forums for judicial review.

The result is no blueprint for change. If one concludes from this study, or from what we have overlooked, that changes are necessary, additional work will be required to flesh out the details.

\section{B. Patterns of Judicial Review}

At common law, relief against unlawful government action was sought in the ordinary courts of first instance. An injured citizen could file for one of the prerogative writs-chiefly mandamus, certiorari and habeas corpus-for an injunction (and later for declaratory judgment), or for damages in tort against the offending officer. A civil or criminal defendant might assert as a defense the invalidity of the regulation or other provision upon which the proceeding was based, and an offending officer could be prosecuted criminally. ${ }^{4}$ In the federal courts, common law certiorari was essentially unavailable, ${ }^{6}$ and, until recently, mandamus lay only in the District of Columbia. ${ }^{6}$ Federal government action could be reviewed in state courts in criminal and damage

2. Id., table B7. The category of "other" U.S. defendant cases-which does not include government property, contracts, torts, or tax cases-numbered 690 in fiscal 1974. Social security cases (246) were separately categorized. Related questions are also presented in civil or criminal district court proceedings to enforce regulatory statutcs.

Judge Leventhal has testified that appeals from district court rulings in review of administrative action "comprise almost all of the so-called 'U.S. Civil' cases component of the District of Columbia Circuit's workload," which in turn "is now running 32\% of filings in 1974." He added: "[u]ndoubtedly, a disproportionate number of such filings are in the District of Columbia," despite the Mandamus and Venue Act of 1962, 28 U.S.C. $\$ \S 1361,1391(\mathrm{e})(1970)$. Statement by Judge Leventhal Before Commission on Revision of the Federal Court Appellate System, May 21, 1974, at 13-14 [hereinafter cited as Statement of Judge Leventhal].

3. Cramton, Administrative Procedure Reform: The Effects of S. 1663 on the Contduct of Federal Rate Proceedings, 16 AD. L. Rev. 108, 111-13 (1964).

4. See, e.g., L. Jaffe, Judicial Control of Administrative Action 152-96 (1965); F. Goodnow, The Principles of the AdMinistrative Law of the United States 378-411 (1905).

5. Degge v. Hitchcock, 229 U.S. 162 (1913). See L. JAFFE, supra note 4, at 166-67.

6. Kendall v. United States, 37 U.S. (12 Pet.) 524 (1838), and cases therein cited. See generally D. CuRRIE, FEDERAL Courts $541-42$ (2d ed. 1975). 
proceedings, ${ }^{7}$ and by way of defense, but state courts lacked authority to issue mandamus $^{8}$ or habeas corpus ${ }^{9}$ against federal officers or, generally, to try federal offenses. ${ }^{10}$

Judicial review reforms in the states, exemplified by the Model State Administrative Procedure Act, often retain the common law principle that administrative action is to be reviewed by the ordinary trial courts. ${ }^{11}$ From the beginning of this century, however, Congress has frequently deviated from this model to provide for review by three-judge trial courts, by the courts of appeals generally, by a single court of appeals, or by a more or less specialized tribunal. The present statutory scheme is a patchwork of these various techniques.

\section{District Court or Court of Appeals Review: Two-Tier or Single-Tier Structures}

\section{A. Formal Administrative Action}

The Federal Trade Commission Act of 1914 set a pattern for many subsequent federal statutes in providing for both review and enforcement of Commission "orders" not in the trial courts but in the several courts of appeals. ${ }^{12}$ Among other agencies whose orders bypass the district courts are the Power, ${ }^{13}$ Communications, ${ }^{14}$ Securities ${ }^{15}$ and Maritime ${ }^{16}$ Commissions, and the Labor ${ }^{17}$ and Civil Aeronautics ${ }^{18}$ Boards.

The rationale for the direct-review model, and its appropriateness for most, if not all, of the agencies to which it applies, are plain enough. The key point is that the district court is unnecessary here because the functions it ordinarily performs in the judicial system are either performed by the administrative agency itself or are relatively unimportant. First and foremost, a court trial need not be held because the record has already been developed at

7. United States ex rel. Drury v. Lewis, 200 U.S. 1 (1906); Teal v. Felton, 53 U.S. (12 How.) 284 (1851). Congress has increasingly allowed the defendant to remove to the federal court, see 28 U.S.C. $\$ 1442(1970)$ and predecessor statutes.

8. M'Clung v. Silliman, 19 U.S. (6 Wheat.) 598 (1821) (dicta).

9. Tarble's Case, 80 U.S. (13 Wall.) 397 (1872).

10. See Warren, Federal Criminal Lazes and the State Courts, 38 Harv. L. Rev. 545 (1924); H. FrIENDLy, FEDERAL JuRISDiction: A GENERAL VIEw 8 \& n.28 (1973). State court jurisdiction to enjoin federal officers surprisingly remains unsettled even today despite the absence of federal jurisdiction in cases of low dollar value. See Arnold, The Pozier of Statc Courts to Enjoin Federal Officers, 73 YALE L.J. 1385 (1964); 28 U.S.C. § $1331(1970)$.

11. 9C Uniform Laws Annot. 174, 183 (1957), 134, 136, 158 (Supp. 1967). The Model Act in earlier or later form has been adopted in at least ten states. See also IrI. Rev. StAT. ch. 110, \& 268 (1968).

12. 38 Stat. $717,719, \S 5$. The present statute is 15 U.S.C. $\& 45$ (c) (1970).

13. 15 U.S.C. \& $717 r$ (b) (1970).

14. 28 U.S.C. \$ $2342(1)(1970)$; 47 U.S.C. \& 402 (1970).

15. 15 U.S.C. § $78 \mathrm{y}(1970)$.

16. 28 U.S.C. \& $2342(3)$ (1970); 46 U.S.C. \& 830 (1970).

17. 29 U.S.C. \& $160(\mathrm{e})$, (f) (1970).

18. 49 U.S.C. \& 1486 (1970), which also makes similar provision for orders of the Federal Aeronautics Administration (FAA). 
the administrative level in trial-type hearings conducted by administrative law judges in accordance with the Administrative Procedure Act (APA). ${ }^{10}$ Second, a district court opinion defining and focusing the issues, frequently useful to the appellate court in other types of litigation, is superfluous because opinions by the administrative law judge or by the agency itself will already have served that purpose. Third, the availability of a convenient and relatively local point of entry into the judicial system, valuable to litigants of modest means in other civil cases, is of much less importance in many areas of administrative review where the economic stakes are typically high and the litigants well able to bear the costs. Finally, the vital screening role which courts of first instance play in holding down the volume of appellate litigation is, once again, played here by the administrative process. Only a small fraction of the cases processed by most agencies wind up in court, and a high proportion of those that do could be expected to reach courts of appeals even if required to pass en route through district courts. The efficiency argument is obvious: Assuming appeal as of right from district to appellate court, ${ }^{20}$ bypassing the trial court significantly expedites tultimate decision, ${ }^{21}$ lessening the burden on both courts and litigants.

Nevertheless, Congress has not invariably placed jurisdiction to review record agency adjudication in the circuit courts. Record review of applications for old age, survivors' or disability benefits under the social security law, for example, is channeled to the district courts by statute. ${ }^{22}$ Until recently, the same was true of administrative workmen's compensation determinations under the Longshoremen's and Harborworkers' Compensation Act. ${ }^{23}$ Similarly, in the absence of specific judicial review provisions, assorted other formal agency adjudications are afforded review in the district courts. The APA makes numerous agency actions reviewable in "a court of competent jurisdiction,"24 and only the district courts enjoy grants of general jurisdiction in the first instance over mandamus actions ${ }^{25}$ or actions arising under federal law. ${ }^{26}$ Examples of district court record review under general jurisdictional provisions include dispositions of mining claims by the Department of the

19. 5 U.S.C. $\$ 556(1970)$.

20. 28 U.S.C. \& 1291 (1970).

21. See, e.g., H.R. REP. No. 1142, 63d Cong., 2d Sess. (1914) (conference decision to substitute direct review of Federal Trade Commission (FTC) orders for the threejudge-district-court procedure passed by the Senate) ; H.R. REP. No. 1086, 87th Cong., 1st Sess. (1961) (expedition was the express reason for extending the direct review procedure to deportation orders of the Immigration and Naturalization Service (INS)).

22. 42 U.S.C. $\$ \S 405(\mathrm{~g}), 421(\mathrm{~d})(1970)$.

23. 44 Stat. 1424, 1436 (1927). A 1972 amendment, 86 Stat. 1251, 1261, 33 U.S.C. \& 921(c) (Supp. III 1973), provides for review by an administrative board and then by the circuit courts. The House Report gives no reason for the change. See notes 128-35 and accompanying text infra.

24. 5 U.S.C. $\$ 703(1970)$.

25. 28 U.S.C. \& 1361 (1970).

26. 28 U.S.C. $\S 1331$ (1970) (subject to a troublesome $\$ 10,000$ amount-in-controversy requirement). 
Interior and of federal employee discharge cases by the Civil Service Commission; both have come under recent attack as time-consuming and out of line with the proper Trade Commission model. District court review, it is argued, "serves . . . no viable purpose."27 The two-tier model assumes that, in some classes of federal agency litigation, district court review does perform a function important enough to justify the obvious cost and delay of an additional stage of litigation.

In the following analysis we shall examine the two models rather more closely, identifying and evaluating the comparative advantages of district and appellate courts as forums for record review of administrative action. We begin by asking, first, what would be gained and lost by district court review if there were no subsequent recourse other than to the Supreme Court on certiorari. We frame the discussion in this way not because we believe singletier district court review a viable option, but because we can more easily isolate the relevant features of the two forums by viewing them independently rather than in coordination. Second, we compare the two-tier model to the single-tier alternatives, assuming a right of appcal to the circuit courts. Third, we add to the comparison a two-tier scheme in which appeals court review is available only on a discretionary basis. Finally, the general considerations which have been set forth are applied to specific agencies that might be thought borderline cases.

1. Single-Tier District Court Review. (a) Appraisal of Advantages. In a single-tier scheme, the district court would have three major advantages over the court of appeals as a forum for review of administrative action. The first is its greater proximity, convenience and, therefore, economy to the private litigant. Appellate courts sit in one or two cities in each circuit, district courts in many more; litigating close to home is presumably less costly. This advantage may be of little importance, as we have said, in big cases, especially when the agencies themselves are highly centralized. But for the social security claimant, the injured longshoreman, the discharged federal worker, access to

27. Polcover v. Secretary of the Treasury, 477 F.2d 1223, 1225-28 (D.C. Cir. 1973), cert. devied, 414 U.S. 1001 (1974) (employee discharge), and cases therein cited. See also Johnson \& Stoll, Judicial Review of Federal Employee Dismissals and Other Adverse Actions, 57 CoRnel. L. Rev. 178 (1972); Strauss, Procedures of the Department of the Interior with Respect to Mining Clains on Public Lands 170-71 (1973) (Report prepared for Administrative Conference of the United States, published in 1974 UTAF L. REv. 185, 266):

Given a formal hearing process within the agency, the results of that process

should have the consequences normally accorded agency hearings on-the-record: a review proceeding brought directly to the United States Court of Appeals in which the standard applied for review of factual issues is substantial evidence upon the record as a whole. District courts have no special expertise or function to warrant continuation of the present two-tiered structure for review; rather, they have seemed somewhat at sea, and far from uniform in their, approach to review .....

In Polcover, for example, the time spent in the district court was twenty-seven months. 477 F.2d at 1227 . 
a convenient forum may be thought essential if the expense of litigation is not to swallow the recovery or price it beyond pursuit. "The obvious theory of a district court venue," wrote Professor Jaffe, "is that the typical plaintiff is a person of modest means."28

Yet the difference in litigation costs between district court and circuit court review should not be exaggerated. More than a third of all civil litigation in federal district courts is brought in cities where circuit courts also sit.20 For this large category of litigants, the court of appeals is no more costly or inconvenient than the district court. Furthermore, many of those who must travel to a court of appeals must also travel, though less far, to a district court. The ninety-four federal judicial districts (including the Virgin Islands, Puerto Rico, Guam, and Canal Zone)-on the average, less than two per state-are not "local" in the way the county courthouse is. Finally, in the record review of agency action, a court of appeals, even when significantly more distant, is not a great deal more costly. A trial is not needed; witnesses need not be transported; added costs may be limited to a small difference in filing fees ${ }^{30}$ and to the attorney's transportation, food and, perhaps, lodging costs plus traveltime compensation for the single day of oral argument, ${ }^{31}$ if indeed there is one. The increasing use of summary procedures by courts of appeals ${ }^{32}$ reduces the cost advantage of the district court, as it reduces the quality advantage of the appellate court. Thus, while it is incorrect to say that litigating in the circuit court "should cost no more," 33 the saving is not on a grand scale; we guess it to be anywhere from zero to $\$ 600 .{ }^{34}$

28. L. JAFFE, supra note 4, at 158. It was on this ground that the Motor Carrier Lawyers Association, speaking for the small trucker, opposed (almost uniquely) the transfer of Interstate Commerce Commission review to the circuit courts. Sec Hearing on H.R. 13927 Before House Comm. on Interstate \& Foreign Commerce, 90th Cong., 2d Sess. 32 (1968). In the Agricultural Adjustment Act, 7 U.S.C. § 1365 (1970), Congress carried this policy one step further, providing the farmer aggrieved by his assigned production quota with the additional option of a state court forum. Sec Developm ments in the Law: Remedies Against the United States and Its Officials, 70 HARv. L. REv. 827, 906 (1957). The same policy helped induce Congress in 1958 to forbid removal of state court workmen's compensation cases, 28 U.S.C. \& 1445 (1970), and in 1962 to allow mandamus actions to be brought outside the District of Columbia, 28 U.S.C. $\$ 81361$ 1391(e) (1970). See S. REP. No. 1830, 85th Cong., 2d Sess. 6-10 (1958); S. REP. No. 1992, 87th Cong., 2d Sess. 3 (1962).

29. The data upon which this statement is based are found in 1974 A.O. REPORT, supra note 1 , table $\mathrm{C} 3$.

30. Filing fees are $\$ 15$ in the district court, $\$ 50$ in the circuit courts, see 28 U.S.C. $\S 1914$ (1970); note following $i d$. \& 1913 (Supp. III 1973). This difference is not only small; it is also not immutable. Since the provision of the federal appellate rules that briefs may be produced "by any duplicating or copying process which produces a clear black image on white paper," FED. R. APP. P. 32, has been read, at least in the Seventh Circuit, to allow xerox copies of typed briefs, there seems no reason to expect a difference in printing costs. In any case, such a difference would argue for modifying the printing rules, not for dispensing with circuit court review if that appeared otherwise desirable.

31. See generally Carrington, Crowded Dockets and the Courts of Appeals: The Threat to the Function of Review and the National Law, 82 HARv. L. REv. 542, 606, 608 (1969).

32. See note 52 infra.

33. Johnson \& Stoll, supra note 27, at $194 \mathrm{n} .89$ (1972).

34. Round-trip coach fare on the less expensive days between Honolulu and Los 
We must note, too, the possibility that district court review may be costlier and less convenient to the Government. Where an agency's cases are managed by United States Attorneys in the field, those stationed in cities where courts of appeals are located frequently acquire a special competence in handling litigation from a particular agency; to distribute that litigation among the district courts would force the Government either to assign cases to local federal attorneys who lack that expertise or to pay for circuit-riding by those who have it. Much the same applies to agencies that organize their attorneys on a regional basis more or less paralleling judicial circuits. ${ }^{35} \mathrm{Ex}-$ pense to the Government, however, cannot alone justify denying private litigants a convenient forum within their means. If the district court were costlier to the Government than the circuit court to the private litigants, efficiency might dictate the latter as the forum, but fairness would require that the private parties be compensated for their travel time and expense. ${ }^{36}$

The second and more significant advantage of single-tier district court review is the conservation of judicial resources: the reduction, by two-thirds, of the number of judges required to decide each case. This does not mean a commensurate reduction in the number of judge-hours per case. A single district judge cannot handle as many cases in a given time as a three-judge appellate panel. Although the panel may perform some judicial tasks in triplicate, opinion-writing, the most onerous task of all, falls to only one judge per case. A recent time survey by the Third Circuit indicates that a judge spends roughly half ( 48 percent) of his case time writing opimions. ${ }^{37}$ Half of the overall appellate effort would not be reduced at all by substituting singlejudge review; the other half would be reduced by two-thirds; the overall saving of judge-hours would be one-third. ${ }^{38}$

A third advantage of the district court over the circuit court, going both to efficiency and to quality, is the greater flexibility with which it can be expanded to meet rising caseload demands. This flexibility flows from the fact

Angeles is $\$ 253.33$ (per United Air Lines information office, Sept. 20, 1974) ; flight time is long enough so that the attorney can probably expect to spend a full working day and a night in the process. If he charges for eight hours' travel time at $\$ 35$ per hour, lives on the federal $\$ 40$ per diem, and spends $\$ 20$ for taxis, we add $\$ 340$. We have disregarded the cost of traveling to Honolulu from a remote island to make connections, since that must be borne to reach the district court too.

35. Those agencies which handle or supervise their own litigation from Washington, or which rely on the Civil Division of the Department of Justice, might have no strong preference in terms of cost, but could find it more difficult to maintain centralized supervision if forced to meet the district courts' shorter time periods for response.

36. See Carrington, supra note 31 , at 606,608 n.277.

37. Federal Judicial Center, 3d Circuit Time Study (November 16, 1972).

38. An example may clarify: If a circuit court panel requires a total of 30 judgehours to decide one case-15 for opinion-writing and 15 (as per the Third Circuit time study) for everything else-a single district judge would need only 20 hours-15 for opinion-writing and five for everything else. This reckoning ignores the time spent by appellate judges in conferring and in writing dissenting or concurring opinions; to that extent, it slightly understates the savings accomplished by district court review. According to the Third Circuit time study, id., the latter functions consume 5.7 percent of the appellate judge's case time. 
that district courts are not expected to maintain consistency among their own decisions. The appellate courts, on the other hand, strive not only to resolve conflicts of decision within and between districts but also to maintain harmony among their own decisions through en banc procedures that become both costly and awkward when too many judges are involved. The essential difference, as Judge Friendly has explained, is that the appellate courts are intended to be far more collegial. ${ }^{39}$ In testimony before the Commission on Revision of the Federal Court Appellate System, judges have vigorously argued for limiting the courts of appeals to nine members, a number already equalled or exceeded in several circuits. ${ }^{40}$ If we assume that these courts cannot be further enlarged, it becomes clear that, even if the basic cost of judge-time were the same at both levels, a given volume of cases could more seriously impair the quality of adjudication in the courts of appeals than in the district courts. This is not to say that enlargement of the district courts through the appointment of additional judges is altogether painless. The larger the court the more difficult it becomes to administer it efficiently and to preserve a semblance of uniformity in its rulings. But once a sufficient diversity of viewpoint and attitude is represented, additional judges are not likely to increase very much the risk of disuniformity or unequal justice. The fourth advantage of the district court is its superiority on occasions when, despite the existence of an administrative record, evidence must be taken. Sanctions for the violation of National Labor Relations Board (NLRB) orders, for example, ${ }^{41}$ depend not only upon the validity of the order, which can be determined from the agency record, but also upon proof of its later violation, which was not in issue before the Board. Similarly, the propriety of interim relief against either an order or its violation pending judicial review ${ }^{42}$ may depend upon facts respecting the balance of hardships that are outside the agency record. ${ }^{43}$

39. H. FrIENDLY, supra note 10, at 29-31, 40-46 (1973).

40. See Digest of Testimony Received by the Commission on Revision of the Federal Court Appellate System in Connection verith Hearings Aug.-Sept. 1973 (Statements of Chief Judge Seitz on behalf of the Third Circuit judges; Statement of Judges Gewin, Morgan, Clark, Coleman, Godbold, Dyer, Simpson and Bell).

41. 29 U.S.C. $\$ 160(\mathrm{e})(1970)$.

42. See, e.g., 29 U.S.C. \& $160(\mathrm{e})$, (f) (1970), authorizing temporary relief when review or enforcement is sought of an NLRB order. General authority of the same nature is conferred by the All Writs Act, 28 U.S.C. \& 1651 (1970) ("all writs necessary or appropriate in aid of their respective jurisdictions").

43. We do not view the erstwhile constitutional requirement of a judicial "trial de novo" of certain "jurisdictional" or "constitutional" facts found on the record by administrative agencies, see, e.g., Crowell v. Benson, 285 U.S. 22 (1932), as presenting additional occasions for evidence-taking in the circuit courts. This doctrine has been in serious decline in the last several decades, sec $4 \mathrm{~K}$. Davis, Administrative Law TrEatise 156-61 (1958); Jaffe, Judicial Review: Constitutional and Jurisdictional Fact, 70 HAR:. L. REv. 953, 973 (1957). Moreover, if the requirement has any vitality at all, it seems likely it will be satisfied by a judicial redetermination of the facts on the basis of the agency record; Crowell itself spoke repeatedly of the need for an independent judicial "determination." The power to remand to permit additional evidence and the authority to ignore administrative findings seem fully to assure complete judicial control of any administrative proceeding. Congress seems to share our conclusion that no judicial trial is necessary under Crowell, for it recently transferred review of longshoremen's injury 
Taking oral testimony in open court is a highly inefficient procedure for three judges ${ }^{44}$ if the incidental functions of enforcement and interim relief imposed the burden of conducting extensive trials in any substantial percentage of cases, the desirability of direct review would be questionable.

There may be no wholly satisfactory solution to the problem of incidental factfinding in contempt or interim-relief proceedings in courts of appeals. Sending these issues back to the agency ${ }^{45}$ or to a master ${ }^{46}$ can cause delay, ${ }^{47}$ and the former gives rise to objections that the agency is made judge in its own cause. ${ }^{48}$ Sending parties to the district court for interim relief ${ }^{49}$ or to enforce orders reviewable in the court of appeals ${ }^{50}$ splits what might be thought a single case between two forums, with varying risks of duplication, conflict, expense and delay.

cases such as Crowell itself from the district courts to the courts of appeals. See note 23 supra.

44. See, e.g., NLRB v. Dell, 309 F.2d 867, 869 (5th Cir. 1962). On occasion the courts of appeals have themselves heard oral testimony. E.g., NLRB v. Lambert, 250 F.2d 801 (5th Cir. 1958). See also NLRB v. Int'1 Ladies Garment Workers Union, 36 CCH LAB. CAS. $\pi$ 65,365 (3d Cir. 1959) (granting temporary relief against a refusal to bargain upon finding irreparable harm on the basis of oral testimony, affidavits and argument).

45. See, e.g., NLRB v. Retail Clerks Int'l Ass'n, 203 F.2d 165 (9th Cir. 1953). Cf. Ilt. ANN. Stat. ch. 110A, $\S 335(\mathrm{~g})$ (Smith-Hurd Supp. 1974) (requiring prior application to the Pollution Control Board to stay its own orders); FED. R. APP. P. 8 (requiring prior application to a district court to stay its judgment or for interlocutory injunction).

46. See, e.g., NLRB v. Giannasca, 119 F.2d 756 (2d Cir. 1941); NLRB v. Little Rock Furniture Mfg. Co., 123 F.2d 868, 871 (8th Cir. 1941); NLRB v. Red Arrow Freight Lines, Inc., 193 F.2d 979 (5th Cir. 1952).

47. See NLRB v. Giannasca, 119 F.2d 756, 759 (2d Cir. 1941) (Clark, J., concurring) (reference to master caused year's delay); Note, The Role of Contempt Proceedings in Enforcing Orders of the NLRB, 54 CoLUM. L. REv. 603, 615 (1954) (two years for remand to Board in NLRB v. Retail Clerks Int'l Ass'n, 203 F.2d 165 (9th Cir. 1953); six years for master in NLRB v. Weirton Steel Co., 146 F.2d 144 (3d Cir. 1944)). Some time can be saved by directing the agency or master simply to take evidence and not find the facts; this procedure also helps to preserve the ultimate authority of the court by avoiding deference to a subordinate trier of fact.

48. See Wallace Corp. v. NLRB, 159 F.2d 952 (4th Cir. 1947); id. at 957 (Soper, $J$, dissenting). It is not clear that the argument has more force here than when the agency enters the original order. See L. JAFFE, supra note 4, at 305-06 (1965). Having the facts as to violation determined by the expert agency reduces the risk of error or of conflict between agency and court as to the legality of the same conduct. See NLRB v. Giannasca, 119 F.2d 756, 759 (2d Cir. 1941) (Clark, J., concurring); Bartosic \& Lanoff, Escalating the Struggle Against Taft-Hartley Contemnors, 39 U. CHI. L. REv. 255, 289 (1972); L. JAFFE, supra note 4, at 307-08.

49. It is perhaps because of the awkwardness of appellate trials that, despite circuit review of final NLRB orders, the statute authorizes only the district courts to grant temporary injunctions against alleged unfair labor practices while the Board considers the merits, 29 U.S.C. $\S 160(\mathrm{j}),(l)$ (1970). In the absence of a specific provision for district court relief before entry of a Board order, the Supreme Court has upheld interim relief by the circuit court under 28 U.S.C. \$ 1651 (1970), in order to protect its future jurisdiction. This procedure requires the circuit courts to find the facts for themselves although, in contrast to requests for interim relief after entry of a final order, the matter is not pendent to a review proceeding already properly in the appellate court.

50. E.g., IlL. ANN. STAT. ch. 11112/2, \$\$ 1041-42 (Smith-Hurd Supp. 1974) (Environmental Protection Act). FTC orders may be enforced either by district court action or, if they have been reviewed and ordered enforced, by a contempt proceeding in the circuit court. 15 U.S.C. $\$ 45(\mathrm{c})$ (1970); id. \$ 45(l) (Supp. III, 1974); see United States v. Bostic, 335 F. Supp. 1312 (D.S.C. 1971) (district court); In re Holland Furnace Co., 341 F.2d 548 (7th Cir. 1965) (circuit court). 
But one should keep the seriousness of the problem in perspective. The reported cases do not suggest that the courts of appeals are suffering greatly from the need to find facts in such proceedings. Given the time pressures surrounding applications for interim relief, we suspect the facts are normally presented by affidavits, which are no special problem for three judges to handle, or in a very brief and thus not terribly burdensome hearing. NLRB contempt cases, those in which the fact problem has been most prominently discussed, have been quite infrequent. ${ }^{51}$ If the countervailing advantages of court of appeals review are considerable, the delays of an occasional remand or the dangers of bifurcated review may be an acceptable price to pay.

(b) The Superior Characteristics of Courts of Appeals. Against the greater economy and convenience of the district court forum must be weighed the great advantages of review in the courts of appeals: its capacity, or perceived capacity, for superior decisionmaking and its ability to develop and maintain a uniform and coherent case law for a large geographical area. The qualitative superiority, if it exists, can be attributed to three principal considerations. First, and by far the most important, is the multi-member composition of the appellate court. The process of collegial decisionmaking tends to counteract bias, subjectivity and incompetence. The need to persuade colleagues, and the opportunity to be persuaded by them, bring reason to the fore and subordinate considerations that cannot be defended in argument. Moreover, if one in three members of a district bench is inept, one in three cases will be decided ineptly; in a court of appeals, ineptitude would more often be outvoted. Besides, multi-judge review helps to minimize the extent to which litigative outcomes are determined by "the luck of the draw," the fortuities of judicial assignment. The decision of a panel of three judges chosen from a bench of nine is far likelier to be representative of the views of the whole court than a decision by one of twenty district judges. Nowhere is this value more important than in the review of certain types of administrative action, where outcomes so frequently reflect, in subtle ways, the philosophy and public policy preferences of the judge.

A second element of superiority is the supposed overall higher caliber of the appellate bench. Because of its greater rarity, superior authority, wider territorial jurisdiction, and consequent prestige, a seat on the appellate bench attracts men who would not accept a district judgeship. Furthermore, district judges are recruited almost exclusively from the ranks of the trial bar, whereas appellate judges are drawn from the profession as a whole and, at least in theory and to a considerable extent in practice, from the best of the district judges.

51. See Bartosic \& Lanoff, supra note 48, at 256-58. Only 164 contempt cases had been brought as of 1971 for an average of five cases per year, with a high of 23 in all circuits in 1969 . 
Third, apart from the qualifications he brings to the bench, the appeliate judge is better equipped by his judicial experience as a whole for the task of reviewing administrative action. Evaluating the decisions of other judges is his daily business. Trial judges, on the other hand, are more accustomed to exercising discretion, less accustomed to reviewing its exercise, less practiced in applying a standard of adjudication that requires them to defer and, therefore, more prone to substitute their judgment for that of the responsible administrative official. This contrast, we suspect, is somewhat overdrawn. District judges, though unaccustomed to passing upon prior judicial action, are regularly called upon to decide whether evidence is or would be sufficient to support a jury verdict, and the thought process required for that determination is not very different from that required in reviewing the findings of a lower court or an administrative agency. A more important difference, we think, is that a circuit court judge has greater opportunity than a district judge to familiarize himself with the substantive law of taxation, labor relations, securities regulations, and so on. One of thirty district judges in a circuit can expect to hear no more than 3 percent of the total caseload in any field; one of nine appellate judges will hear 33 percent of that caseload. It is no wonder that practitioners so frequently complain of the difficulty of making district judges understand the complexities of their particular specialty. A related difference is that appellate judges are more accustomed to deciding, and writing opinions on, questions of substantive law than district judges, who spend the greater part of their time conducting trials and ruling on procedural questions and who rarely write opinions of any great length.

A reservation must be entered, however. The quality advantage of the court of appeals, like the efficiency advantage of the district court, is weakened by the increasing practice of the former of deciding cases without oral argument or written opinion..$^{52}$ Indeed, where such summary procedures are used, it might well be argued that the advantage is reversed. A litigant, given a choice, might reasonably prefer to have his case decided by a single district judge who offered him an opportunity to be heard in person in support of or in opposition to a motion for summary judgment rather than by an appellate panel that denied that opportunity.

Whether or not the circuit court is in fact the superior forum, it is clear that most litigants, both private and governmental, believe it to be and would not readily accept the district court as a substitute. Indeed, it is fair to say

52. For a comprehensive description and analysis of the practice, see Haworth, Screcuing and Sumnary Procedures in the United States Courts of Appeals, 1973 WASH. U.L.Q. 257. See also Bernard G. Segal, The Case for Preserving Oral Argument in the United States Courts of Appeals, speech to the American College of Trial Lawyers, March 19, 1974. In fiscal year 1972, of 12,455 cases decided (less consolidation), 3,918 ( 31.5 percent) were disposed of without oral argument or submission on briefs, 8,987 (72.2 percent) without signed opinion, and 4,995 (40.1 percent) without any written opinion. 1972 A.O. REPORT, supra note 1 , table 12, at 104. 
that judicial review by a federal court of more than one judge has come to be looked upon as a matter of basic right in all cases, civil and criminal, administrative and nonadministrative. If the litigant who loses in a district court trial is entitled to review by a circuit court, would the loser before a mere administrative body settle for less? This sense of entitlement, whether or not justified, reinforces the objective considerations favoring appellate review. ${ }^{63}$

Another argument often made in favor of appellate review of administrative action is that it would be unseemly and demeaning for a single district judge to set aside the decisions of an expert administrative agency, especially one that itself is multi-membered. Nor is the point solely one of protocol: The risk of error is especially high when the judgment of one prevails over that of many. The argument from seemliness, however, applies less strongly to some agencies than to others. It applies full force to the great independent regulatory commissions whose members are appointed by the President with congressional approval and enjoy a secure, if limited, tenure. The element of indignity dwindles, however, when the agency is of lesser stature-for example, tbe Board of Immigration Appeals in the Department of Justice or the Appeals Council within the Department of Health, Education and Welfare (HEW), both quasi-judicial tribunals created and terminable by departmental regulations, and staffed by members appointed and removable at will by the respective heads of their departments ; or even the Benefits Review Board in the Department of Labor, a statutory body, to be sure, but otherwise not very different from the other two.

Whether the superior decisionmaking ability of a three-judge tribunal would alone justify its added cost-and, in the case of the court of appeals, the reduction of collegiality brought about by the need for increased membership-is a complicated question. At the outset, it should be emphasized that the greater likelihood that an issue or controversy will be decided correctly by three heads than by one is not generally deemed a sufficient reason for committing it to three judges. Decision in the first instance is nearly always entrusted to a single judge, most of whose determinations (not only on questions of specific facts, but also on questions of inference, interpretation, discretion, remedy, and so on, are subject to narrowly limited review, assuring that the one judge will not be second-guessed by the three unless he goes egregiously wrong. Moreover, the use of multi-judge panels for the review of district court decisions in ordinary civil and criminal litigation does not necessarily imply a societal judgment that correction of egregious error is a more important or demanding function than initial decision, or so important or de-

53. The litigants' preference for a multi-judge forum, however, cannot be decisive so long as the added costs of such first-class justice are not borne by the litigants themselves through fully compensatory user fees. Of course, a party prefers a better tribunal if he can get it for nothing. If they had to pay their way, many consumers of judicial services, at least in some types of litigation, might well opt for the small economy size. 
manding as to justify the additional costs of multiple judges. The plurality of appellate judges can be sufficiently explained by two other factors: the unseemliness of letting a single judge undo the work of another; and their responsibility not only to correct error in the particular case, but, more importantly, to maintain a coherent body of law over a broad geographic area-a duty which does justify, and perhaps demand, a premium brand of adjudication.

Whether the correction of egregious error would alone justify the costs of multi-judge review may well vary according to the nature of the case. First, the greater the significance of the matter to be decided, the more resources society may be justified in spending in an effort to decide it correctly. An investment of judicial time that might seem indispensable in passing upon Power Commission rates for a whole new gas field, for example, might appear an inexcusable luxury in determining the ownership of a bicycle. Similarly, the difficulty of the case may be relevant to the appropriate investment of judicial resources. The advantages of a highly qualified, multiple-judge panel may be especially important in cases where the technical difficulty of the questions enhances the risk of error.

The importance one attaches to the advantages of a multi-judge court for the correction of error will take on significance when we evaluate two-tier review. But for purposes of comparing systems of single-tier review, the decisive advantage of the court of appeals is its capacity to develop and maintain a coherent, reliable and uniform case law for a fairly large geographical region. As suggested earlier, the importance of correctly deciding legal issues that transcend the particular case argues strongly in favor of providing a firstclass forum. Moreover, apart from the quality of decision, the very freedom from cumbersome en banc procedures that gives the district courts significant advantages in terms of ability to accept additional workloads disables them, whether their judges sit singly or in threes, from performing the lawmaking function. As courts of first instance, those in heavily populated areas inevitably have large caseloads which necessitate too many judges to be able to achieve even district-wide, let alone circuit-wide, uniformity. At best, single-tier district court review would settle legal issues one district at a time, leaving the law uncertain elsewhere in the circuit and promoting litigation. At worst, it would generate a host of inconsistent decisions within and between districts, unresolvable short of the Supreme Court, which has difficulty finding time even to iron out conflicts among eleven circuit courts. It would be bad enough that interdistrict conflicts would result in unequal treatment of parties similarly situated. It would be intolerable that conflicts within a single district would make it impossible to determine the legality of conduct at the allimportant planning stage. Single-tier district court review is, therefore, 
simply unthinkable; only the court of appeals, with its broad territorial jurisdiction and with judges few enough to keep in step with one another, can maintain a tolerable degree of uniformity.

The advantages of the district court-convenience, judicial economy and flexible membership-are all possible only because we do not look to it for uniformity. It is the need for uniformity of decision over a wide geographic area that prevents the circuit courts from becoming conveniently "local" forums and, by placing a ceiling upon their membership, makes them vulnerable to caseload pressures that threaten the quality of adjudication. And it is also the need for uniformity (along with desire for quality and fear of unseemliness) that accounts for the use of expensive multi-member panels; deciding singly, appellate judges would generate too many conflicts for feasible resolution en banc. In sum, the achievement of uniformity carries a price tag, but clearly an acceptable one.

2. Mandatory Two-Tier Review: Appeal as of Right. Having assessed the relative advantages of circuit court and district court review on the assumption that each were to be terminal, subject to Supreme Court certiorari, we can now move to the more practical comparison between direct court of appeals review and a two-tier system in which district court orders are appealable, either as of right or with leave, to the circuit courts. First, we shall examine "mandatory two-tier review" (appeal as of right); in the following section, we shall add "discretionary two-tier review" (leave to appeal) to the comparison.

(a) Two-Tier or Direct Court of Appeals Review. The critical advantage of mandatory two-tier review over single-tier district court review is that it provides a mechanism for the resolution of inconsistencies within and between districts and for the achievement of circuit-wide uniformity. This benefit is not without considerable cost in those cases where appeals are taken, but the price is undoubtedly worth paying in order to avoid the intolerable discordance and uncertainty that would result, in nearly all areas of administrative review, if there were no recourse beyond the district court.

The more difficult problem is to justify mandatory two-tier review as against direct circuit court review. In every case eventually appealed to the circuit courts, interposition of the district court substantially increases the cost of litigation and delays the resolution of the controversy. These costs are difficult to quantify with any confidence. The litigant must pay double filing fees and brief reproduction costs, and must transport his attorney to two courts instead of to one. He must also pay for extra work by his lawyers (though presumably much less effort is required to prepare for a second appeal on essentially the same questions). The indirect costs of the added delay, both to the particular parties and to the systen, are more elusive. Delay may induce parties to settle on terms less just than would be imposed by a court decision; 
it may cause deterioration of evidence that must be used if there is a retrial; similar cases may have to be litigated until the disputed point of law is settled; it also increases the harm done by a challenged practice or by its temporary restraint during the period of litigation..$^{54}$

Nor are the disadvantages of two-tier review limited to those cases in which appeals are taken. Perhaps the most unfortunate consequence of adding the district court stage is that it prices the appeals court beyond the reach of many litigants. The party who loses in the district court may stop at that point, not because he is satisfied or even resigned, but because he is exhausted. When that occurs, the objection is not only that the exhausted litigant has been denied access to a superior forum, as under a single-tier district court system, but that he has effectively been excluded from a superior forum that is available to more affluent litigants. Further, if the cost of another appeal is sufficiently great in comparison to the stakes in an entire class of cases, interposing the district court could create substantial disuniformity.

Four countervailing advantages might be claimed for two-tier review, three of them carrying little weight. First, whereas in other areas of litigation an appellate court can profit greatly from a lower court opinion focusing the issues, weighing the opposing arguments and pinpointing relevant portions of the record, that advantage is minimal in the review of on-the-record administrative action, where even without a district court opinion, the court of appeals has the benefit of at least one, and often two, formal opinions below-by an administrative law judge and by the agency head (or heads). The district court, we might add, is in no better position than the appeals court to evaluate the administrative record and findings; it applies exactly the same standard of review, and performs an essentially duplicative function..$^{55}$ Second, the district court, as we have already observed, is closer and cheaper; sometimes that may matter. If there are some for whom two-tier review prices the appeals court beyond reach, there may be others for whom the alternative approach prices judicial review itself beyond reach. Others, though able to afford the appeals court, might nevertheless prefer the cheaper forum, and doubtless many more would if required to bear the full cost of multi-judge adjudication. ${ }^{56}$ But since, as suggested above, the added costs of court of appeals review are apt to be slight and, in any event, the litigant will find his district court triumph cheaper only if the Government chooses not to appeal it, we do not think district court convenience a weighty argument. Third, while initial district court review of record agency decisions would admittedly eliminate factfinding diffculties incident to circuit court enforcement or interim relief, we cannot be-

54. On the evils of delay, see H. Zeiser, H. Kalven \& B. Buch holz, Detay in the CourTs (1959). See also Carrington, supra note 31 , at 554.

55. Polcover v. Secretary of Treasury, 477 F.2d 1223, 1226-27 (D.C. Cir. 1973), cert. dettied, 414 U.S. 1001 (1974). But see Nickol 'v. United States, 501 F.2d 1389, 1391 (10th Cir. 1974).

56. See note 53 and accompanying text supra. 
lieve, for reasons indicated above, ${ }^{57}$ that these occasional difficulties are serious enough to justify the resulting waste of resources and the impaired quality of adjudication.

The only really important justification for two-tier review is the possibility that a great many cases will not be appealed beyond the district court and the appellate courts will be relieved of a significant part of their workload. Just how low the appeal rate (the percentage of district court decisions appealed to the circuit courts) must be in order to make two-tier review worthwhile is difficult to say. More could be said if the sole objective were to minimize the amount of judge-time required for the review of formal administrative action. Earlier we estimated that a court of appeals decision might require about three judge-hours for every two required by a district court decision. On that assumption, a 10 percent appeal rate would yield a reduction of more than 20 percent in overall expenditure of judge time, and a rate of about 30 percent would be the "break-even" level at which the amount of district-judgetime exactly equalled the reduction in appellate-judge-time. ${ }^{.8}$

The number of judge-hours required for the review of an administrative action is not, however, the only appropriate measure of judicial efficiency for our purposes; accordingly, a favorable appeal rate may not be a necessary condition for the adoption of two-tier review. We have already seen that the courts of appeals are a scarce resource, less easily expanded than the district courts; hence, a measure that reduces the pressure on them might be justified. even though the overall demands upon the judicial system as a whole were thereby increased, if the alternative seriously impaired the collegial nature of the appeals courts. Thus, even if the appeal rate were much higher than the break-even level, the absolute number of cases filtered out of the circuit courts might still be great enough to justify a more-than-equal increase in judge-time at the district court level.

We need hardly add that a low appeal rate, if not a necessary condition for two-tier review, is also not a sufficient condition. The very considerable disadvantages in terms of cost and delay to some litigants, and effective denial of court of appeals review to others, must be carefully weighed against any savings to the judicial system, and these savings must be substantial. An analogy may help to put the issue in perspective. Routing review of record administrative action initially to the district court has much the same advantages and

57. See notes 41-51 and accompanying text supra.

58. Using the estimated ratio between district judge and circuit court time $(2: 3)$ developed at note 38 and accompanying text stupra, a single district judge would invest 10 units of judge time in deciding 10 cases; if there were direct review three circuit judges would invest 15 . Appcal in one case in 10 would add one and a half more units (diminished to the extent that the appellate court relies upon the opinion below); appeal in three in 10 would add four and a half. These crude estimates are meant merely to be suggestive; any proposal for legislative action or inaction should be supported by statistical information expertly collected and expertly analyzed. 
disadvantages as the insertion of a new single-judge court between district court and circuit court in ordinary civil and criminal cases, which we doubt many would find desirable. ${ }^{59}$ The comparison may suggest that two-tier administrative review, even in the less important cases, ought to be viewed not as an ideal but as a possibly unavoidable evil.

The relevant search, then, is to identify readily definable categories of administrative cases whose diversion to the district courts in the first instance would spare courts of appeals a burden of decision that threatens their ability to function as collegial bodies, or, less compellingly, that is not worth their time. In any event, in order to minimize the countervailing costs, two-tier review should be applied first to those categories of cases generally simple or trivial enough to be least deserving of the effort of three judges. ${ }^{60}$

3. Discretionary Two-Tier Review: Appeal by Leave. We have thus far assumed that appellate court review, whether direct or indirect, would be available as a matter of right. The alternative, a two-tier system in which leave to appeal from district court decisions would be granted or denied by the court of appeals on a discretionary basis, deserves investigation.

A proposal to this effect was made by Judge Friendly in his Carpentier lectures:

[W] here review of administrative action lies in the district court and that court has affirmed, appeal should be only by leave of the court of appeals. The argument would be that it is enough to grant an aggrieved citizen one judicial look at the action of a disinterested governmental agency, unless a superior judicial body believes the case presents a problem going beyond a particular instance. ${ }^{61}$

Under Judge Friendly's proposal, district court decisions adverse to the administrative agency would continue to be reviewable as of right; only for the private litigant would review be conditional. Arguably, such a scheme would meet the crux of the objection that it is unseemly for a single judge to reverse with finality the decision of a high-status multi-member board. The unseemliness, perhaps, lies not in district court review per se but merely in giving a district court final say when it reverses an agency. The very considerations-

59. On this possibility, see H. FRIENDLY, supra note 10, at 430: "One regards with horror what might be considered still another tier of courts, with the attendant delay and expense."

60. Case-by-case determination of the appropriate forum would make for maximum precision at the cost of a considerable sifting burden and delay; we would not recommend it. A jurisdictional-amount requirement for direct review would help to strain out cases of little immediate significance, but would inhibit ultimate court of appcals resolution of the important legal questions that may often arise in the smallest cases. Moreover, despite years of precedents, such a requirement might result in wasteful jurisdictional litigation, and administrative decisions concerning such matters as deportation or union election do not lend themselves to ready translation into money equivalents. See generally D. CuRRIE, supra note 6 , at 504-43. Thus, even though the present statutory practice of prescribing the reviewing forum according to easily administrable categories bears only a rough correspondence to the relevant policies, we think it the most promising approach.

61. H. FRIENDLY, supra note 10, at 176. 
the expertise, stature and multiple membership of the agency-that weigh against finality for the district court when court and agency disagree, arguably weigh in favor of finality when court and agency concur. Equality of access between litigants, needless to say, cuts against any such distinction and would argue for putting both parties to the hazard of discretionary review.

Another important variable is the standard to be used in accepting or rejecting cases. At one extreme, leave to appeal might be granted only in cases involving important issues of law, or intracircuit conflicts, or, possibly, large immediate stakes. At the other pole, all but patently frivolous appeals might be accepted. An intermediate approach would grant review not only in the important cases but also in cases of patent error below.

(a) Appraisal of Advantages. The advantages of mandatory two-tier review over direct review in the courts of appeals, it will be remembered, depend upon the expectation that losing parties in the district court will often decide not to take a further appeal. Discretionary two-tier review allows us to increase those advantages by artificially depressing the rate of appeal. Thus, in a field where the high frequency of expected appeals would obviate any substantial economies from mandatory two-tier review, making appeals discretionary might make interposition of the district court worthwhile. Similarly, in fields where mandatory two-tier review does produce significant economies, there may still be a substantial burden on the courts of appeals that discretionary review could further lessen.

Discretionary review, however, would require in every appealed case a determination now required in none: whether to grant or deny leave to appeal. The added burden of this preliminary screening must be weighed against whatever savings might be gained through obviating a decision on the merits in those cases where leave to appeal is either not requested or is denied. Those savings are, in turn, suspect in view of the increasing tendency of appellate courts to decide "easy" cases by summary procedures that dispense with formal opinion and oral argument. If leave to appeal were denied only in patently unmeritorious cases, the number of applications for review would not be greatly reduced; a high proportion of them would be granted; and nothing would be gained even in leave-denied cases, since nearly every such case would be one which, on the merits, would be decided summarily, and since the decision whether to grant or deny leave would involve virtually the same judicial thought process as the decision on the merits. If, on the other hand, leave were granted only in cases presenting an important issue of law, and were rigorously denied even in potentially meritorious cases not presenting such an issue, the savings could be more substantial. Fewer applications for leave would be filed; fewer of them would be granted; fewer of those denied would, if decided on the merits, be dealt with by summary procedures; and the thought process in deciding whether to grant or deny leave would be more abbreviated 
than that required for decision, even summary decision, of the merits. Fishing through 4,000 annual certiorari petitions may be a whale of a job for the Supreme Court, but it is surely paltry in comparison to deciding all those cases on the merits.

There are some who would prefer discretionary review to wholesale use of summary decision procedures, even if it were not more efficient. Their position is that oral argument is often an essential input, even in cases that at first may appear open-and-shut; that an opinion setting forth reasons is an obligation of the judicial office; and that a decision dispensing with both is no proper decision at all. Rather than pretending to decide the merits and, in the process, elevating an unreviewed district court decision to the status of a circuit precedent binding on other district judges, the court of appeals should, like the Supreme Court, simply decline to review-an action supposedly having no precedential importance. If the courts of appeals behaved as if appeals were discretionary, surely it would be preferable to legalize and properly label what they are doing. But it is not wholly true that the appeals courts are treating review as discretionary; a cursory review of the merits is better for the parties than no review at all. The significant argument for discretionary review, for our purposes, is judicial economy.

(b) Appraisal of Disadvantages. The disadvantages of discretionary review are immediately obvious and weighty. To a greater degree than with mandatory two-tier review, the appeals court would be removed as a forum for the correction of error and bias. In every run-of-the-mill case, a lone district judge would have final say. It is serious enough to exclude litigants from the superior forum by raising the price of admission; it is more so, especially in the important sense of appearances, to refuse admission at any price. The agencies themselves, assuning they, too, had no automatic right to review, might be persuaded to live with such an arrangement if satisfied that the circuit courts would be open to them in the cases that really mattered. For the ordinary private litigant, however, to whom the "routine" case is anything but routine, denial of recourse beyond the district court might be harder to swallow, especially if it were denied (as it would have to be) only to a very few classes of litigants.

Discretionary two-tier review also has the further disadvantage of added cost and delay for litigants. However much or little it may conserve the resources of the judicial system, discretionary review would do nothing to conserve the resources of the parties. If the screening procedure used by the courts of appeals were modeled on the Supreme Court's certiorari procedure, the appellant would have to file not one but two briefs-first, a petition for review arguing the "certworthiness" of the case, and, if that were successful, a full brief on the merits. The price of admission to the court of appeals would thus be siguificantly increased. It is possible that the appeals courts would not 
choose to pattern their screen on Supreme Court certiorari ; instead, they might simply require a single brief presenting both reasons for granting leave and the merits. If so, legal fees would not be appreciably different than under mandatory review, but petitioners denied leave would get much less for their money.

The cost factor, however, is probably less important than the factor of delay. The discretionary approach, by sandwiching an additional stage of decision between district court and plenary appellate review, would inevitably prolong the process of judicial review of the particular agency action involved. To be sure, the delay would be mitigated in part by the time saved through reduction of the appellate courts' on-the-merits caseload. And for litigants generally, the process of judicial review would be shortened, not prolonged; that follows from our assumption that discretionary review would result in an overall net saving of time for the courts of appeals. But while the benefits thus obtained would be shared by all circuit court litigants, the burden of delay would be borne exclusively by litigants in the particular categories to which the leave-to-appeal procedure was applied. Members of that class would be worse off, and could fairly claim discrimination, whether denied appellate court review or merely forced to wait longer and pay more for it than others.

In short, for the appellant who is denied leave or discouraged from seeking it, discretionary two-tier review has nearly the same disadvantages as singletier district court review. From the standpoint of the system as a whole, however, the overriding flaw of single-tier district court review is absent, for discretionary access to a court of appeals may be sufficient to settle questions of law and to resolve intracircuit conflicts.

On the strength of this analysis, we conclude that agency action is unsuitable for discretionary two-tier review unless two conditions are met. First, the volume of appeals must be large and burdensome, even after filtration through the district courts; otherwise, curtailment of the right to appellate review would not be worth the candle. ${ }^{62}$ Second, the proportion of those appeals involving legal issues or important interests must be very small; otherwise, leave to appeal would be granted too often to achieve real savings. Moreover, even if both conditions are satisfied, the need must be very great indeed to justify outright denial of appellate court review, if there is any reason to believe that the decisions of district courts would systematically differ from those that would be reached by circuit courts; that is, that denial of automatic review would be outcome-determinative in any substantial number of cases. A high reversal figure indicates that district courts in this field are more than

62. The discretionary approach would be appropriate, however, where two or more agencies, each generating a relatively small caseload, are combined for review purposes, producing a large aggregate caseload. Indeed, the more agencies subjected to this approach, the less basis there is for the objection that a particular class of litigants has been singled out. 
ordinarily prone to error or bias and, therefore, that circuit court review serves an especially significant error-correcting function. In particular, it would be unfortunate to deny private litigants challenging governmental action access to appellate courts in categories of cases in which the district courts are, in general, less sympathetic forums.

4. Specific Agencies. (a) Social Security Administration. (1) Current Practice: Mandatory Two-Tier Review. A natural testing ground for these generalizations is the Social Security Administration (SSA), a subdivision of HEW, which appears at the present to be the most significant instance of a federal agency whose adjudications on a formal administrative record are reviewable in the district courts in the first instance. ${ }^{63}$ In fiscal year $1974,3,585$ social security cases were filed in the district courts, ${ }^{64}$ yet only 246 district court decisions were appealed to the circuit courts. ${ }^{65}$ If one looks at a slightly longer period, and assumes a one-year lag $^{66}$ between the two stages of review, the appeals rate seems to be about 10 percent, ${ }^{67}$ roughly the same as that for district court cases generally. ${ }^{68}$ About 80 percent of the social security cases involve claims for disability benefits; the balance involve claims for health insurance, retirement and survivors' benefits.

That the appeal rate is not higher is due in part to the Government's own policy of restraint in challenging adverse decisions. From the inception of the disability insurance program in 1955, through 1973, the Government appealed only 102 district court reversals, barely 5 percent of the total. ${ }^{69}$ Its policy is to appeal only if the case appears to have serious administrative implicationsthat is, is contrary to statute, regulations, or administrative practices and might have a precedential effect on future cases; mere error in the application of the "substantial evidence" standard of review will not be challenged.70

Disability claimants, too, have tended to settle for a single round of review, appealing only 12 percent of all district court defeats since the program

63. 42 U.S.C. $\$ 405(\mathrm{~g})(1970)$.

64. 1974 A.O. REPORT, supra note 1 , table C2.

65. Id., table B7.

66. The median time interval from filing to disposition in district court social security cases is 10 months. 1973 A.O. REPORT, supra note 1 , table C5A.

67. Social Security Administration Cases, 1970-74

$\begin{array}{ccc}\text { Fiscal ycar } & \begin{array}{c}\text { district court } \\ 1970 \\ 1,735,\end{array} & \text { court of appeals } \\ 1971 & 1,792 & - \\ 1972 & 2,288 & - \\ 1973 & 2,497 & 193 \\ 1974 & 3,585 & 246\end{array}$

1972-74 A.O. REPORT, supra note 1, tables B7 and C2. Assuming a one-year lag between district and circuit filings in the case, the 649 appeals in the last three years are ten percent of the district court cases filed in 1971-73.

68. See 1973-74 A.O. REPORT, supra note 1, tables B3 and C2.

69. Staff of House Ways and Means Comm., 93D Cong., 2d Sess., Report on the Disamility Insurance Program 262 (Comm. Print 1974) [hereinafter cited as ComMITTEE STAFF REPORT].

70. $I d$. at 266 . 
began. ${ }^{71}$ The explanation probably lies in a combination of factors-the exhaustion of the litigant's resources, a recognition that the stakes do not justify a second round of litigation costs, and a realistic appreciation of the odds against success. ${ }^{72}$ Attorneys, many of whom take disability cases on a contingency basis in the hope of earning the "reasonable fee" provided for by statute,$^{73}$ may be willing to gamble on a single appearance before a familiar district judge but not to risk further time and money on a long-shot try in a more distant forum.

(2) Appraisal of Direct Court of Appeals Review. Even on the basis of present figures, cited above, one can see that direct review of social security cases would bring a major increase in the appellate caseload. If every case now brought to district court were brought to a court of appeals-and presumably most would be, since the added costs of the latter are likely to be trivial ${ }^{74}$ - the increase would be on the order of 20 percent of the total present caseload of all circuit courts, nearly tripling the present number of direct administrative review cases. ${ }^{75}$ But the present fignres do not begin to suggest the expected magnitude of the social security caseload problem in the very near future. In the seven-year fiscal period 1967-73, social security filings in the district courts more than doubled. ${ }^{76}$ In fiscal 1974, they rose by another 48 percent as the first black lung benefit cases came to the courts under the Coal Mines Health and Safety Act of $1969 .{ }^{77}$ Black lung litigation is expected to increase dramatically in the next two years, and then, so far as SSA is concerned, to drop off as that agency ceases to be responsible for the program. ${ }^{78}$ In the long run, a much more prolific source of litigation will be the Supplemental Security Income Program, ${ }^{79}$ which as of January 1,1974 , provides for a federally guaranteed monthly income to replace the former state programs of aid to the aged, blind and disabled. Claims under this statute are already moving through the multi-tiered processes of the SSA in about half the volume of the regular disability claims ${ }^{80}$ and are expected to equal that volume. The first wave of these cases has not yet broken upon the district courts, but it has been estimated that by 1976 district court filings in the combined disability programs

71. Id. at $269-70$.

72. More than 80 percent of all disability appeals have been decided in the Government's favor by the courts of appeals. Id. at 270 .

73. 42 U.S.C. \& 406(b) (1970) (not to exceed 25 percent of past-due benefits).

74. See notes 29-36 and accompanying text sipra.

75. See notes 1-2 and accompanying text supra.

76. 1967-73 A.O. REPORT, sipra note 1, table C2.

77. 30 U.S.C. \& 801 (Supp. II, 1972).

78. Under the Coal Mines Health and Safety Act, black lung claims filed prior to January 1, 1974 are administered by HEW; claims subsequent to that date are filed pursuant to applicable state workmen's compensation laws certified by the Secretary of $\mathrm{HEW}$ as having adequate coverage, or absent such certification, are administered by the Department of Labor under the provisions of the Longshoremen's and Harbor Workers' Compensation Act. 30 U.S.C. \$\$ 924, 931-32 (Supp. III, 1973).

79. 42 U.S.C. \& 1381 (Supp. II, 1972).

80. Committee Staff RePort, silpra note 69 , at 164. 
will have reached the staggering total of 10,000 per year, nearly ten percent of total civil filings in fiscal year $1974 .{ }^{81}$ Nor is the burden of this caseload evenly distributed throughout the judicial system. In fiscal 1974, about 20 percent of all social security cases were filed in three judicial districts (Eastern Kentucky, South Carolina and Puerto Rico), and nearly 40 percent in eight districts, mostly in the Fourth, Fifth and Sixth Circuits and specifically in the Appalachian region. ${ }^{82}$

The impact of these new programs has not yet been felt by the circuit courts-yet even without them social security appeals have doubled since $1970 .{ }^{83}$ If the 10,000-case projection for the district courts comes true, and if the historic 10 percent appeal rate holds, the courts of appeals will be receiving upwards of 1,000 social security appeals within four years, nearly 70 percent of them in the Fourth, Fifth and Sixth Circuits. ${ }^{84}$

In view of these developments, it would be manifest folly to institute direct circuit court review. Indeed, this would be true even if the appeal rate were many times greater than it is. Two-tier review means greater expense and delay for those litigants who persevere to the appellate stage but lesser expense to the 90 percent who do not. And while many of those who accept the verdict of the district court do so because they cannot afford to go further, this consideration seems decisively outweighed by the saving-one is tempted to say salvation-to the judicial system through avoidance of what might conceivably be a 30 percent increase in the appellate court caseload. ${ }^{85}$

(3) Appraisal of Discretionary Two-Tier Review. The more difficult question is whether court of appeals review ought not be made discretionary in social security cases. The conditions outlined earlier seem fairly well satisfied. Although the present volume of appeals would not justify such a departure from the tradition of appellate review as of right, the projected volume, especially if concentrated in three circuits, could well have a discernible effect on the quality of adjudication. ${ }^{86}$

81. Id. at 4.

82. 1974 A.O. REPORT, supra note 1, table C3.

83. See note 67 supra.

84. See CoMmitteE Staff Report, supra note 69 , at 270.

85. See notes 1-2 and accompanying text supra.

86. An alternative possibility would be to expand the number of circuits so as to provide additional manpower without impairing the ability of individual courts to maintain a uniform law of the circuit. Every such mitosis, it may be objected, reduces geographical diversity, enhances the power of individual Senators over the appointment process, and increases the risk of intercircuit conflicts that the Supreme Court may be too busy to resolve. See, e.g., H. FRIENDLY, supra note 10, at 39-41; Carrington, supra note 31 , at $580-87$. We share Judge Friendly's reservations as to the extent to which additional circuits would mean additional conflicts. If eleven courts agree on an issue, the chance that a twelfth or even a twentieth will disagree seems remote indeed. The problem of single-Senator dominance of a one-state circuit could be met in the New York City area, for example, by drawing circuits that would include portions of New Jersey and/or Connecticut as well as of New York. Splitting a state between circuits has its problems, but it has already been formally proposed for California by the Commission on Revision of the Federal Court Appellate System, and an extensive argument has been 
The second condition - that relatively few appeals would be allowed under a discretionary procedure-is also probably met. It is plain that a high proportion of all social security cases involve purely evidentiary issues. More pertinent, and less clear, is whether the same can be said about the much smaller subclass of cases in which appeals are now taken. Since the Government appeals only 5 percent of its district court reversals and selects those on the same criteria that circuit courts would use in granting leave, discretionary review would not substantially weed out this class of appeals. Private litigants, however, who appeal more than twice as often, use less stringent criteria; one assumes that their contribution to the circuit court caseload would probably be materially reduced by a discretionary filter.

The third consideration - that the substitution of discretionary for mandatory review should have no systematic effect on the outcome of litigationpresents a more difficult question. The Government's petitions for review will, in the main, be granted; those we can ignore. The question is whether discretionary review would deprive social security claimants of a forum generally more favorable to them than the district courts. The answer is probably not but depends to some extent on how one evaluates certain figures. If one ignores remands and technical dismissals, more than four out of five disability appeals are decided in the Government's favor in the circuit courts. But counting remands as losses-not unreasonable since seven of every eight appeals are by the claimant-the Government's batting average falls to a less reassuring 67 percent. ${ }^{87}$ In any case, there is solid evidence that district court review is no mere rubber stamp. Prior to 1968, the SSA's record in the district courts was notably unimpressive, a majority of cases ending either in reversals or remands. ${ }^{88}$ Since that time, it has fared somewhat better, partly because of a 1968 statutory amendment tightening the definition of disability ${ }^{89}$ and partly

made that the problems of a split state are not very serious. See Hellman, Lcgal Prollems of Dividing a State Between Federal Judicial Circuits, 122 U. PA. L. Rev. 1188 (1974). To develop fully the disadvantages of dividing the circuits and to compare them with those of the present social security pattern is beyond the scope of this study.

87. Committee Staff Report, supra note 69 , at 270.

88. In 1965, two district judges observed that in a several-month period in 1965, the SSA had been either reversed or remanded in 63 (according to one) or 75 percent (according to the other) of the cases. Scott v. Celebrezze, 241 F. Supp. 733, 736 (S.D.N.Y. 1965); Seldomridge v. Celebrezze, 238 F. Supp. 610-20 (E.D. Pa. 1965). Unpublished figures compiled by SSA show that in the fiscal year period 1965-67, the Secretary was affirmed in 48 percent of all social security cases, reversed in 26 percent, and remanded in 26 percent. Social Security AdMinistration, Dep't of Healtir, Edication, and Welfare, Operational Analysis of the Bureat of Hearings and Appeals 31 (June 30, 1973) [hereinafter cited as HEW, Operational ANalysis]. Published figures, unfortunately, do not record the number of remands. They show that in disability cases in which the Secretary's decision was either affirmed or reversed, the affirmance rate in the period $1955-67$ was 66 percent; and that if total dispositions are deemed to include affirmances, reversals and cases in which benefits were allowed after court remands, the affirmance rate was 48 percent. CoMmitTEE STAFF REPORT, supra note 69 , at $269,271$.

89. Act of January 2, 1968, Pub. L. No. 90-248, \$\$ 104(d) (5) -106, 156(e)-159(b), 81 Stat. $833,867-69$, codified in scattered sections of 42 U.S.C. (1970). 
because of increasingly rigorous review of benefit-denials within the administrative process. ${ }^{90}$ In the fiscal period 1968-73, the SSA was affirmed in 58 percent of all social security cases, reversed in 14 percent and remanded in 28 percent.91 These figures suggest that district court review, on the whole, is searching and sympathetic, and that placing appellate review on a discretionary basis would not leave claimants' rights inadequately protected.

We conclude that while denial of access to a court of appeals is not a step to be taken without compelling justification in the interest of a sound and effective judicial system, the proper circumstances for such a move may well be present, or imminent, in the social security area. ${ }^{92}$

A similar analysis should be made before adopting the suggestion of transferring review of such actions as Interior Department mining claims or federal employee discharges from district courts to the courts of appeals. ${ }^{93}$ As with social security, we suspect the issues in both classes of cases are largely evidentiary and, especially in the employee cases, the immediate stakes relatively small. We have no information as to the number of mining cases; it appears that perhaps 200 employee cases were filed in the district courts in fiscal 1974, and we know of 28 appeals. ${ }^{94}$ An extra 170 cases of this nature annually would not destroy the circuit courts (though over half the appeals were in a single circuit, the District of Columbia), but it is worth considering whether, given the caseload problem, even such an addition is justified. The more significant question is whether initial district court review of several such relatively small categories might in the aggregate provide substantial relief to the courts of appeals.

90. Under the established procedure, a claimant dissatisfied with the determination of the state agency, both initially and upon reconsideration, is entitled to a hearing before a federal administrative law judge, whose decision is reviewable in turn, either sua sponte or upon the claimant's request, by an Appeals Council, 20 C.F.R. $\$ \S 404.901$ 404.990 (1974); see CoMmitTeE STAFF REPORT, supra note 69, at 31-33. In the period $1960-73$, the rate of reversals, both at the hearing and appeals levels, has dramatically increased. Reversals by administrative law judges increased from 19.3 to 52.1 percent; reversals by the Appeals Council, from 3.6 to 12.3 percent. See CommtrteE Staff Report, supra note 69 , at $77,247,249,254$.

91. HEW, OPERATIONAL ANAlysis, supra note 88 , at 31 . House Ways and Means Committee statistics, which are somewhat less complete, indicate that in the period 1968-73, in disability cases either affirming or reversing the Secretary, the affirmance rate was 81 percent, rising to 85 percent in 1973. If total dispositions are taken to include benefitallowances after court remand, the affirmance rate for the same period is 62 percent, rising to 64 percent in 1973. CommitTeE STAFF REport, supra note 69, at 269, 271.

92. The further question is whether steps should be taken to protect the district courts from the expected flood of social security cases. The fact that these litigants have already run the gauntlet of initial hearing and administrative review suggests that to interpose still another administrative hurdle might be practically tantamount to denying judicial review. The substantial disadvantages of creating a special court, constitutional or legislative, for social security cases are detailed below. See text following note 347 infra. We think that, given the noncollegial nature of the district courts, the best solution may be to appoint additional district judges.

93. See note 27 sipra.

94. The General Counsel of the Civil Service Commission has informed us that 401 such cases were filed in all courts in fiscal 1974 and that in fiscal 1969 roughly half of such cases were filed in the Court of Claims. The appeal figure we derive from detailed information furnished by the Administrative Office to the Administrative Conference. 
(b) National Labor Relations Board. (1) Current Practice: Direct Court of Appeals Review. The Labor Board seems, at first blush, a natural candidate for two-tier review. Its unfair labor practice decisions-reviewable in courts of appeals is either enforcement actions by the Board or review actions by the charged party ${ }^{95}$-make up by far the largest contribution of any agency to the direct-review caseload. In the last five fiscal years, they averaged 652 cases annually, 40 percent of all direct-review cases and nearly 45 percent of those outside the District of Columbia..$^{90}$ Here, if anywhere in the administrative area, there might seen a real opportunity for pruning. Moreover, Labor Board cases-unlike, for example, ratemaking or license decisions of the transportation and energy regulatory agencies-are not obviously unsuitable for initial district court review by virtue of their subject matter. Typically, they involve narrow questions of specific fact and of law, not broad issues of policy or discretion. And the economic interests at stake are often, though not always, too small to be worth pursuing through two levels of judicial review; as a practical matter, the district court would be the last stop.

(2) Appraisal of Mandatory Two-Tier Review. Yet the considerations favoring two-tier review seen to us heavily outweighed by those opposing it. ${ }^{97}$ We might add, though this is not decisive, that we have found no Labor Board attorney or private labor practitioner who does not resist the idea of initial district court review. It is generally felt that district judges, apart from being less capable, on the average, than appellate judges, are also less familiar with the intricacies of the Labor Relations Act. In time, they would no doubt gain experience in labor matters but they could never gain as much as circuit court judges already have-there are simply too many district court judges and too few labor cases. Competence aside, labor relations is an area in which variations in attitude and philosophy among district judges are peculiarly likely to influence litigation outcomes; a multi-member court, with its tendency to neutralize bias, is especially valuable here. At present, the circuit courts, with one exception, are reasonably uniform in their treatment of Labor Board cases, ${ }^{98}$ and there is no assurance that district judges would be like-minded. If

95. 29 U.S.C. \& 160 (e), (f) (1970).

96. 1974 A.O. REPORT, supra note 1, table B3. This figure, however, may be grossly misleading. By the Board's own tally, the number of court of appeals decisions in review of enforcement cases in the period 1970-73 was only 1,384, an annual average of 346. 1970-73 NLRB ANN. REP., table 19. The discrepancy seems to lie in the fact that the Board's figure does not include, while the Administrative Office statistic apparently does, cases resolved by formal court-approved settlements in which the charged parties stipulated either to the dispositive facts or to the entry of a court of appeals judgment. Since the judgment in such cases is pro forma and consumes little if any judge time, it would be advisable, for our purposes, to think in terms of the smaller Board figure rather than the twice-larger Administrative Office figure. Even on this basis, however, the Board's contribution to the appellate caseload remains substantially larger than that of any other agency.

97. See notes 54-60 and accompanying text supra.

98. During fiscal years 1968-72, the percentage of Board decisions affirmed in full in all except the Eighth Circuit, ranged narrowly from 63.6 to 74.3 percent; every circuit, 
they were not, forum shopping could become a much more serious problem for the Board. ${ }^{99}$ Finally, the NLRB is one of the great independent agencies whose prestige makes direct review by a multi-member court seem particularly appropriate. In sum, the superiority, or at least the perceived superiority, of the court of appeals is a factor which in this area deserves more than usual weight.

Furthermore, in terms of efficiency, mandatory two-tier review for the Labor Board would be a doubtful prescription. For litigants who persevere to the appeals court, it would further delay what is already a lengthy process. The filing of a charge, informal efforts by the charging party (first at the regional, then at the national level) to secure issuance of a complaint by the General Counsel, formal hearing, successive decisions by the administrative law judge and by the Board typically consume more than 10 months, judicial review still to come. ${ }^{100}$ District court review would add at least another $\mathrm{six}^{101}$ and in the busier big-city districts where labor litigation is heavy, much more. ${ }^{102}$ All of this might conceivably be justified by the prospect of major savings to the judicial system, but there is no real prospect.

Whether in a two-tier scheme the appeal rate would be low enough to yield a net reduction in total judge-time, or a significant reduction in the appellate caseload, is entirely conjectural. The economic stakes in unfair labor practice cases, and the resources of the litigants, vary widely: A bare indication is the fact that a quarter of the situations that come before the Board involve establishments with fewer than ten employees; another quarter, establishments with 10 to 40 employees; and still another quarter, establishments with 190 or more employees. ${ }^{103}$ Moreover, if employers charged with unfair labor practices frequently pursue judicial review, even in hopeless

that is, was within 10 points of the national percentage of 65.8 percent. The affirmance rate for the Eighth Circuit, however, was only 44 percent. 1973 NLRB ANN. REP., table $19 \mathrm{~A}$, at 251 .

99. Forum-shopping by parties to NLRB proceedings has been the subject of much discussion and concern. See, e.g., Comment, Forum-Shopping in the Reviez' of NLRB Orders, 28 U. CHI. L. REv. 552 (1961). The NLRB itself informs us that its operations are not significantly affected by forum-shopping, sec Letter from Peter G. Nash, General Counsel, NLRB, to Antonin Scalia, Chairman of Administrative Conference, Oct. 25. 1974, but we are told by Professor Clyde Summers, who is preparing a paper on the Board for the Commission on Revision of the Federal Court Appellate System, that shopping is still extensively practiced by private attorneys, despite the increasing uniformity in decisions by the various circuit courts.

100. Hearings on S. 3671 Before the Subcomm. on Separation of Powers of the Senate Comm. on the Judiciary, 91st Cong., 2d Sess. 308 (1970) [hereinafter cited as Hcarings on $S .3671]$.

101. The median time interval, from filing to disposition, in all civil cases in all district courts in fiscal year 1973 was 10 months. Among cases disposed of prior to trial, however, the median time was only six months. 1973 A.O. REPORT, supra note 1 , table C5.

102. In the Southern District of New York, the period from filing to disposition was 25 months; in the Eastern District of Pennsylvania, 17 months. 1973 A.O. REPORT, supra note 1, table C5. There is some dispute as to whether the great urban districts are, in fact, the main loci of labor litigation. See Hcarings on S. 3671, supra note 100 , at 75 .

103. 1973 NLRB ANn. Rep., App. table 18, at 248. 
cases, for the purposes of delay, the two-tier system would play into their hands.

Thus, the picture is mixed: The Labor Board cases lie halfway between the small-litigant, small-stake model exemplified by the SSA and the largelitigant, large-stake model typified by the Federal Power Commission (FPC), Civil Aeronautics Board (CAB), Nuclear Reactor Commission (NRC, formerly the Atomic Energy Commission (AEC)), and by ICC railroad regulation. Mandatory two-tier review does not seem warranted or politically possible.

(3) Appraisal of Discretionary Two-Tier Review. There remains the question of discretionary two-tier review. Its sole advantage would be to assure a reduction in the appellate courts' on-the-merits caseload regardless of the rate of appeal. The present volume of labor appeals seems large enough to make this option worth considering, but the other two conditions we have suggested as prerequisites for discretionary review are not clearly satisfied. One cannot confidently say-as one could, for example, of social security, deportation, or longshoremen's compensation cases-that few Labor Board cases would qualify for discretionary review. A substantial number of such cases do involve issues of law transcending the particular situation, albeit usually narrow and technical questions of statutory construction and, more often, application. The ongoing conduct of labor-management relations frequently depends on there being authoritative answers to these questions. And even many cases challenging the substantiality of the evidence underlying the Board's orders involve important enough interests, either in purely monetary terms or in terms of the ongoing life of the plant, to make them eligible for discretionary review. The caseload savings, while probably substantial, might therefore be rather less than one would expect from the present volume of appeals alone. More important, and in our view decisive, is the widely perceived inferiority of the district court as a forum for labor matters, the felt danger of biased or misguided decisionmaking by district judges unversed in labor law. This consideration alone, we think, demands that the court of appeals be automatically available-if not as a first resort, certainly as a last.

We note, finally, that some good might be done by making Labor Board orders, like those of all other major independent administrative agencies, selfenforcing. This could be done by providing either that the Board's own order should be final unless a petition for review is filed within a specific period or that the Board's order shall be filed forthwith in the appropriate circuit court and entered as the decision of the court unless challenged within a designated period. This reform, recommended in one variation or another by the Administrative Conference ${ }^{104}$ and others, ${ }^{105}$ would have two potential advantages.

104. 1 Administrattve Conf. of the United States, Recommendations ANd REPORTS, ACUS Rec. 10, at 24, 237 (1970) [hereinafter cited as ACUS Rec.].

105. See, e.g., Advisory Panel on Labor-Management Relations Law [the "Cox 
First, it would elininate the period of delay that now elapses between issuance of a Board order and filing of an enforcement action. Second, it would relieve the circuit courts of those cases in which a non-complying charged party, though willing to resist an enforcement proceeding, would be unwilling to take the initiative in contesting the order. We see no justification for the present unique requirement that the Board go to court in order to give teeth to its decisions. Neither, however, would we expect the proposed change to yield more than marginal benefits. Whereas at one time a total of 100 days typically elapsed between issuance of the order and filing of the enforcement action, ${ }^{106}$ the interval has now been reduced to about 30 days. We are told, moreover, by the head of the Appellate Branch of the Board's General Counsel's Office that many recalcitrant employers now abandon their opposition to the order when advised that an enforcement proceeding is about to be, or has just been, filed. ${ }^{107}$ The number of cases removed from the appellate dockets by a selfenforcement provision might therefore be rather small. In any event, as Judge Leventhal has observed, Labor Board enforcement proceedings which are not truly contested are no great burden for the courts. ${ }^{108}$

(c) Immigration and Naturalization Service: Deportation Cases. Current Practice: Bifurcated Review. Deportation orders of the Immigration and Naturalization Service (INS) are another category of cases that might be thought appropriate for two-tier review. Prior to 1961, they were in fact reviewed by district courts, either in habeas corpus or in nonstatutory actions for declaratory or injunctive relief under section 10 of the Administrative Procedure Act. ${ }^{109}$ In that year, Congress, disturbed by "the growing frequency of judicial actions being instituted by undesirable aliens whose cases have no legal basis or merit, but which are brought solely for the purpose of preventing or delaying indefinitely their deportation from this country,"110 added section 106 (a) to the Immigration and Nationality Act. The amendment eliminated the district court stage and gave courts of appeals exclusive jurisdiction to review "final orders of deportation." 111

The wisdom of these amendinents was sharply questioned by Judge Friendly in his 1972 Carpentier lectures. He argued that while the purpose of the legislation was to expedite the deportation of certain notorious aliens able to afford repeated dilatory appeals, in the majority of cases "it has probably had the opposite effect."112 Whereas previously most aliens who failed

Panel"], Report to Sen. Comm. on Labor \& Pub. Welfare, Organizatron and Pro(EDURE of THE NLRB, S. Doc. No. 81, S6th Cong., 2d Sess. (1960).

106. 1 ACUS Rec. 10, supra note 104, at 259.

107. Willingness to comply may be infuenced by recent appellate decisions that a party frivolously opposing a Board order may be liable for the Board's court costs as well as his own.

108. Sec Statement of Judge Leventhal, supra note 2, at 9-10.

109. 5 U.S.C. $\& 703$ (1970). See Shaughnessy v. Pedreiro, 349 U.S. 48 (1955).

110. H.R. Kep. No. 1086, 87th Cong., 1st Sess. 22-23 (1960).

111. 75 Stat. 651, \& U.S.C. \& $1105 a(a)$ (1970).

112. H. FrIENDLY, supra note 10 , at $175-76$. 
to obtain a stay of their deportation orders in a district court did not appeal, the deportee, instead of having to act speedily, "now has six months to file a petition for review and this works as an automatic stay unless the INS moves to vacate it," 113 as it rarely does. Moreover, he noted that the statute "has engendered numerous jurisdictional disputes which have already demanded three Supreme Court decisions and will probably require more." 114 The clear answer, he concluded, was to repeal section 106 (a), return final deportation orders to the district courts, and expect the courts of appeals to give expeditious treatment to those district court orders that are appealed.

There is much to be said for this proposal. Deportation appeals rarely involve questions that transcend the particular case. The most frequent issue is whether the immigration judge acted arbitrarily in denying one of the many forms of relief which the statute commits to the Attorney General's discretion. The resources of a three-judge appellate court are arguably wasted on such deliberations.

Another consideration in favor of restoring deportation orders to the district courts is that it would elininate the bifurcation of review that has resulted from the Supreme Court's interpretations of the scope of section 106(a). Under Immigration Service regulations, a deportation order is issued by an immigration judge after a formal trial-type proceeding, ${ }^{115}$ in which the central issue, unless conceded, is the alien's deportability. Appeal lies to the Board of Immigration Appeals. In addition, however, the statute authorizes a variety of discretionary relief which, if granted, may have a bearing upon the question of deportability or upon the execution of the deportation order. ${ }^{110}$ Certain of these discretionary determinations can be made only by an immigration judge in the course of a formal deportation proceeding; others must be made by district directors of immigration either before, during, or after-but outside the framework of-the deportation proceeding. The question thus posed, one which sharply divided the circuits, was whether some or all of these discretionary determinations were part of the "final orders of deportation" which section 106 (a) makes reviewable in circuit courts. In a series of three decisions, the Supreme Court held that "final orders of deportation" include discretionary determinations by the hearing officer during and incident to the deportation proceeding, ${ }^{117}$ and denials by the Board of motions to reopen de-

113. $I d$.

114. $I d$.

115. 8 U.S.C. $\$ 1252$ (b) (1970); 8 C.F.R. $\S 242$ (1974).

116. E.g., 8 U.S.C. $\& 1153$ (1970) (classification as a preference-immigrant); id. $\$ 1182$ (c) (waiver of inadmissibility); id. $\$ 1182(\mathrm{e})$ (waiver of 2-year residency requirement for exchange visitors); id. \& 1253(h) (withholding of deportation); id. \& 1254(a) (suspension of deportation); id. $\S 1254$ (e) (voluntary departure); id. $\S 1255$ (a) (adjustment of status); $i d . \& 1258$ (change of non-immigrant classification); id. \& 1259 (record of admission for permanent residence).

117. Foti v. INS, 375 U.S. 217 (1963). 
portation proceedings, ${ }^{118}$ but do not include non-record discretionary determinations by district directors altogether outside the deportation proceeding. ${ }^{119}$ The latter are still reviewable exclusively in district courts.

This split-level scheme of review has evoked a good deal of criticism. Professor Davis has argued that the present bifurcated structure produces confusion, wasteful jurisdictional litigation and piecemeal review, and should be replaced by a single judicial remedy, be it at the district or appellate court level. ${ }^{120}$ The Immigration Service itself favors the latter solution. It maintains that the continued availability of district court review for non-record discretionary determinations defeats the congressional purpose to shorten the deportation process and minimize stalling tactics; and in 1971 it proposed legislation to broaden section 106 (a) so as to make all deportation-related decisions reviewable solely by circuit courts. ${ }^{121}$ This approach is open to the persuasive objection that it would add to the already bulging dockets of the appellate courts a class of cases-non-record discretionary determinations by immigration field officers-that could hardly be less suitable for appellate review. The alternative solution-returning record determinations to the district courtsseems, from that standpoint, far preferable.

Furthermore, even if one assumed that interposition of the district courts would, in the net, increase somewhat the total time required for judicial review of deportation, the savings from direct appellate review would probably be quite small in relation to the total period of review, especially in those cases, of principal concern to Congress, in which the alien is determined to postpone deportation as long as possible. ${ }^{122}$ The ability of determined aliens to postpone the evil day has very little to do with the existence of two levels rather than a single level of review. It has everything to do with the persistence and ingenuity of counsel in plying the INS with new applications for discretionary relief, the denial of which then provides a pretext for successive challenges in

118. Giova v. Rosenberg, 379 U.S. 18 (1964).

119. Cheng Fan Kwok v. INS, 392 U.S. 206 (1968).

120. K. DavIs, supra note 43, \& 23.03, at 798-99 (1970 Supp.).

121. H.R. 2328, 92d Cong., 1st Sess. \& 7 (1971). Professor Jaffe also appears to favor this solution. L. JAFFE, supra note 4, at 422 .

122. The point is well illustrated by some of the "horror stories" cited by the House Judiciary Committee in describing the dilatory tactics sought to be remedied in section 106 (a). H.R. REP. No. 565, 87th Cong., 1st Sess. 7-11 (1961). The most notorious instance was that of Carlos Marcello, who was ordered deported in February, 1953, yet after seemingly endless litigation still remained in the country in June, 1961.-Marcello filed five successive district court proceedings challenging either the district court deportation order or the denial of discretionary relief. Three times he appealed to the courts of appeals (once successfully). Twice he carried his case to the Supreme Court. Among the many circumstances that conspired to frustrate efforts at deportation, the availability of district court review was a very minor one. All told, the five district court proceedings consumed about 15 of the nearly 100 months during which Marcello evaded banishment. Furthermore, nearly half of the months were spent in the two proceedings in which, because the trial court proceedings were not appealed, only a single stage of review occurred. 
court. That avenue of abuse would in no way be widened by a transfer of responsibility from appellate courts to district courts. ${ }^{123}$

It might, of course, be objected that district court review would be useless at best, and at worst highly mischievous, in an area where litigants so frequently have no object other than delay. Their cases, one might expect, would inevitably reach the court of appeals anyway. Yet this is far from clear. It is noteworthy that in fiscal year 1961, the last full year before section 106(a) went into effect, 162 deportation cases were commenced in the district courts of the Second Circuit, yet only 15 appcals were docketed in the circuit court. ${ }^{124}$ It may well be, moreover, that a deportation case can be decided more quickly in a district court than in a circuit court. The great majority of declaratory judgment actions challenging the denial of discretionary relief by district directors are disposed of on the Government's motion for summary judgment or the plaintiff's motion for preliminary injunction within weeks, often within days, of their commencement. In the circuit courts, on the other hand, the process of briefing, argument and decision regularly requires several months. True, this pattern is now changing as courts of appeals, beset by mounting caseloads, increasingly resort to summary or abbreviated procedures. But until those procedures are more widely used, the district courts, by and large, will continue to be the more expeditious forum at the initial stage of review.

(2) Appraisal of Two-Tier Review. Despite all we, and Judge Friendly, have said, restoration of district court review of deportation orders does not promise sufficient advantage to make it worth the while. Unlike social security, deportation does not present a caseload problem of significance. In the fiscal period 1970-74, while the total caseload of the circuit courts was increasing by about 40 percent (from 11,662 to 16,436 ), the deportation component declined by about the same percentage (from 413 to 237) and its share of the total from 3.5 to 1.4 percent. ${ }^{125}$ This drop is surprising in view of the sharp increase in aliens apprehended by the INS, and hearings held by immigration judges, during the corresponding period. Indeed, the judicial trend may be reversing itself. In the last two years, deportation cases have rather sharply increased (from 175 to 237). But even if the caseload continues to rise in this

123. In the eyes of many knowledgeable government attorneys, the truly mischicvous feature of the present scheme of revicw is not the continuing role of district courts but the automatic stay of deportation once appeal is perfected to the circuit court. 8 U.S.C. $\S 1105 a$ (a) (3) (1970). They point out that whereas district court review adds days or weeks to the deportation process, court of appeals review typically takes months, and the automatic stay provides this respite even for the patently dilatory appellant.

This argument might have been highly persuasive before the advent of summary review procedures in the appellate courts. It is much less so now that those procedures enable the courts to dispose of patently frivolous petitions on roughly the same showing by the Government, or lack of showing by the alien, which would be needed to deny a stay of deportation even were it discretionary. Moreover, the automatic nature of the stay matters far less than the attitudes of the judges.

124. See Foti v. INS, 308 F.2d 779, 785 n.6 (2d Cir. 1962), rev'd, 375 U.S. 217 (1963).

125. 1974 A.O. REPORT, supra note 1 , table B3. 
fashion, it will remain relatively small, and the extent to which two-tier review would reduce it is largely speculative. To be sure, the burden is not uniformly distributed among the circuits. The Ninth is by far the busiest with nearly half the cases in fiscal 1972; the Second a distant runner-up that year with about 13 percent. ${ }^{126}$ For the Ninth Circuit, a district court screen might be of some help; for other circuits, the relief would be negligible.

The argument for two-tier review as an antidote to bifurcation is also ultimately unpersuasive. Bifurcation does not seem to us as great a problem as it seems to many others. The element of uncertainty that once surrounded the jurisdictional issue, and generated three Supreme Court and countless circuit decisions, has now been greatly reduced by the drawing of a bright line between decisions of immigration judges, reviewable only by courts of appeals, and decisions of district directors, reviewable only by district courts. Few competent lawyers are any longer apt to find themselves (by mistake, at least) in the wrong court.

To be sure, bifurcation may, as Professor Davis observed, result in fragmentary review of a single deportation case in those situations where the district director's determination could be reviewed at the same time as the order of deportation but must be routed instead to the district court for separate treatment. But this problem could easily be cured by a holding that the district director's determination is reviewable along with the deportation order on a theory of pendent jurisdiction. ${ }^{127}$ Furthermore, the bifurcated system does not create, and its elimination would not cure, what is perhaps the most serious source of delay and multiple litigation in the deportation area-the ability of the alien to file successive petitions for review from successive denials of administrative relief, limited only by the seemingly inexhaustible ingenuity of counsel and the patience of the courts. Elimination of district court jurisdiction might shorten each round of review, but it would not reduce the number of rounds.

In sum, we see no great advantage in a return to two-tier review. There are, moreover, at least two hazards: the risk that the extra stage of review will be exploited for delay; and the danger, feared by attorneys on both sides, that district judges are more apt to be swayed by subjective attitudes for or

126. These figures were obtained from the Administrative Office of the United States Courts; we have no reliable figures for later years.

127. The Supreme Court has expressly declined to decide whether a circuit court, entertaining an appeal from a final order of deportation, might have "pendent jurisdiction" to review a denial of discretionary relief. Cheng Fan Kwok v. INS, 392 U.S. 206, 216 n.16 (1968); compare Dong Yup Lee v. INS, 407 F.2d 1110 (9th Cir. 1969) (reviewed denial of visa petition presented during pendency of deportation hearing, but found no authority to review similar denial before proceeding commenced), and Dibadj v. INS, 411 F.2d 983 (3d Cir. 1969) (denial of waiver for exchange visitor after deportation proceedings completed held not reviewable with deportation order), with Wei-Ming Chang v. INS, 418 F.2d 1334 (9th Cir. 1969) (denial of waiver for exchange visitor before commencement of deportation, jurisdiction assumed and denial upheld), and Perdido v. INS, $420 \mathrm{~F} .2 \mathrm{~d} 1179$ (5th Cir. 1969) (same). 
against the alien than multi-member appellate courts. We note, finally, that we do not find the present scheme as irrational and conceptually untidy as many critics do. That the informal discretionary determinations of an administrative official should be reviewed in the first instance by a single district judge (capable, if need be, of taking evidence) while the formal, on-the-record, albeit equally discretionary, determinations of a quasi-judicial hearing officer should be reviewed directly by a court of appeals does not, in principle, seem offensive.

(d) Department of Labor: Longshoremen's Compensation and Black Lung. (1) Current Practice: Direct Court of Appeals Review. Prior to 1972, decisions of deputy commissioners-officers who investigated claims and held hearings-under the Longshoremen's and Harbor Workers' Compensation Act of 1927 were subject to review in the district courts. ${ }^{128}$ This was entirely understandable: The stakes and the litigants (at least the claimants) were typically small, and issues of law or policy rarely presented. The volume of cases, to be sure, was not high. In the five-year period from November, 1963 to June, 1968, there were about 70 district court filings annually, and in later years they declined to a low of 44 in fiscal $1972 . .^{120}$ We do not have solid data on the number of appeals from district to circuit courts, but it appears there were fewer than 20 per year. ${ }^{130}$ In 1972, Congress amended the Act to provide for direct court of appeals review of longshoreman compensation cases. At the same time, it added a stage of review to the adminiștrative process by establishing a Benefits Review Board ${ }^{131}$ to receive appeals from the decisions of administrative law judges, to whom the hearing functions previously conducted by deputy commissioners were now assigned.132 The change in the judicial review provision is not explained in the legislative history, but one can reasonably assume it reflected a congressional judgment that the added opportunity for administrative review made the district court review unnecessary and potentially exhausting.

One might have thought that the institution of direct review would pro-. duce a substantial increase in caseload for the courts of appeals, perhaps even to the level previously experienced by the district courts. This does not appear to have happened. From March, 1973, when the change went into effect, to November, 1974, only 19 longshoreman compensation cases were filed in the circuit courts, ${ }^{133}$ less than one per month as compared to the nearly four per month average in the district courts in the last full fiscal year before the

128. 44 Stat. 1436, 33 U.S.C. \& 921 (Supp. II, 1972).

129. These incomplete figures were supplied us by members of the staff of the Solicitor of the Department of Labor.

130. According to figures supplied us by the SSA, there were five filings and 19 decisions at the circuit court level in fiscal 1972, and nine decisions in fiscal 1970.

131. 33 U.S.C. § 921 (Supp. II, 1972).

132. Id. § 919 (Supp. II, 1972).

133. These statistics were supplied us by the office of the Solicitor of the Department of Labor. 
amendment, and to the nearly six per month in the late 1960's. Indeed, it is not clear that the new procedure has added anything at all to the appellate dockets.

We can only speculate as to the reason. One possibility is that litigants found the district court a more inviting forum. The other, much more likely, possibility is that for many litigants the new Benefits Review Board is serving as a substitute for the district court, meeting their need for a forum in which to challenge the decisions of the hearing officers and thus making it unnecessary for them to go to court. In the first eleven months of 1974, well over 200 appeals were filed with the Board in longshoreman cases, ${ }^{134}$ all of which, if pressed at all, would previously have been routed directly to the judicial system. In sum, the Board seems to be performing for the circuit courts the same screening function that district courts usually perform. The moral of the story seems to be that the best way to reduce the judicial burden of reviewing administrative action is to provide a sufficiently lengthy process of administrative review within the agency. Unfortunately, the opportunities for that are distinctly limited; the former procedure under the Longshoremen's Act, which sent the decisions of hearing officers directly to the courts, was rare, if not unique.

The number of longshoreman cases in the courts of appeals will increase substantially in the next few years, if only because, as another of the 1972 amendments, Congress expanded the coverage of the Act to include injuries incurred in areas-for example, piers, wharfs, terminals-adjoining the navigable waterway itself.. ${ }^{135}$ This extension has virtually doubled the volume of compensation claims. Even so, it is clear that longshoreman's cases present no major caseload problems for the courts of appeals and no great opportunity for savings.

(2) Potentially Increasing Caseload Burden: Appraisal of Need for Two-Tier Review. One cannot be at all sure this will remain the case with respect to black lung compensation claims filed after January 1, 1974, which, pursuant to the Black Lung Act of $1972,{ }^{136}$ are administered, in the absence of an approved state worknien's compensation scheme, by the Secretary of Labor in accordance with the provisions of the Longshoremen's and Harbor Workers' Act. ${ }^{137}$ The shift of administrative responsibility for black lung claims from Social Security to Labor was natural enough, since the post-1973 claims are governed by what is essentially, a workmen's compensation scheme, with primary liability for payment of benefits assigned to employers rather than to the Government. Nevertheless, the transfer has created an anomaly

134. As of November 20,1974, 208 cases had been filed with the Board during the calendar year.

135. 33 U.S.C. \& 903 (Supp. II, 1972).

136. 30 U.S.C. $\S \S 901-941$ (Supp. III, 1973).

137. Id. $\$ \S 931-32$ (Supp. III, 1973). 
and, potentially, a problem. Whereas the black lung cases administered by Social Security are reviewed in the first instance by district courts, those administered by the Labor Department will be reviewed directly by circuit courts. The question thus arises whether the caseload considerations which virtually rule out direct review in the former area may not apply to the latter as well.

Since the Benefits Review Board has not yet decided its first black lung case, it is hard to estimate what the judicial burden will be. In fiscal 1974, 464 black lung cases were filed against the SSA in district courts; nearly as many (450) were filed in the first four months of fiscal 1975-200 in October alone, the last month on record. With the caseload thus rising, and with the number of Appeals Council (the final stage of administrative review) filings for the first quarter of fiscal 1975 more than doubling those for the entire fiscal ycar 1974,138 it would not be surprising if district court filings for the year exceeded 3000 . We hasten to reassure the reader that there is no danger the Labor Department's black lung litigation will approach this scale. The great majority of those eligible for benefits filed their claims prior to 1974; the number of claims received by the Labor Department is therefore very much smaller than the number received by SSA. ${ }^{139}$

Even so, it is evident that the volume of black lung cases directly reviewable by the courts of appeals could be very substantial. Indeed, superficially at least, one might expect a given number of administrative decisions to generate a larger volume of court litigation with respect to post-1973 cases than for those filed earlier, since the former involve not only the traditional medical issues that go to eligibility but also difficult problems of employer liability. Labor Department attorneys, however, foresee no caseload problem for the circuit courts. They acknowledge that a number of important legal issues, mainly jurisdictional, will have to be litigated in the first year or two of operation, but after that they expect a gradual decline in filings. They anticipate that coal mine operators will, for the most part, acquiesce in administrative determinations of liability, at least where the staff has built a proper record, and that the medical issues will present many fewer difficult factual questions than the pre-1974 claims, since a great proportion of the latter were filed by older miners and widows and had to be decided on the basis of stale records. SSA.

138. These figures were supplied by the Bureau of Hearings and Appeals of the

139. Figures supplied by the Management Information and Appraisal Branch of the Office of Administration of the SSA indicate the number of black lung claims received at the intake level for fiscal 1972 and subsequent years as follows:

$\begin{array}{lr}1972 & 75,337 \\ 1973 & 148,985 \\ 1974 & 82,799 \\ 1975 \text { (July 1-Nov. 20) } & 18,425\end{array}$

The 1974 and 1975 claims, though filed initially with SSA, are administered by the Labor Department. 
We are not able to assess these predictions with any confidence. We suggest, however, that black lung litigation may prove to be a source of serious, if temporary, docket pressures for the courts of appeals a year or two from now, and that it bears close watching. If it were concluded that initial district court review would significantly reduce appellate dockets, we see no telling objection on other grounds.

\section{B. Informal Rulemaking}

1. Direct Court of Appeals Review: Rule-Order Distinction. Statutes providing for judicial review commonly speak of "orders," which the Administrative Procedure Act defines as final dispositions in matters "other than rule making." 140 It is no surprise that this definition was never read into the statute providing for three-judge district court review of ICC "orders,"141 since that agency's substantial ratemaking business, though later classified as "rule making" by the APA, ${ }^{142}$ was clearly meant to be included. Under the same statute and others based upon it, the Supreme Court has also construed "orders" to include general regulations adopted under the informal notice-andcomment provisions of the APA. ${ }^{143}$ Thus, the Supreme Court in CBS v. United States ${ }^{144}$ held the FCC's chain-broadcasting regulations reviewable by a three-judge district court under a statute that incorporated the ICC provisions, and in United States v. Storer Broadcasting Co., ${ }^{145}$ after review of FCC "orders" had been transferred to the circuit courts, held its regulations directly reviewable there. In both cases the Court may have been influenced by the fact that the alternative was no review at all; it focused solely on questions of standing or ripeness for review, not discussing whether review should have been sought in a regular district court.

Nevertheless, the District of Columbia Circuit in the influential case of United Gas Pipe Line Co. v. FPC ${ }^{146}$ refused direct review of a Power Commission regulation under a statute similar in wording to the ICC provision. The statute, said the court, provided for "substantial evidence" review on the record at the instance of a party to the adninistrative proceeding. These provisions were said to contemplate "review of a decision based on evidence presented in a quasi-judicial proceeding before the Commission," 147 and to "evidence Congressional recognition that an appellate court has no intelligible basis for decision unless a subordinate tribunal has made a record fully encompassing the issues."148 United Gas Pipe was immediately followed by a

140. 5 U.S.C. \& 551(6) (1970).

141. Now 28 U.S.C. \$§ 1336, 2325 (1970).

142. 5 U.S.C. $\$ 551(4)(1970)$.

143. Id. $\$ 553$.

144. 316 U.S. 407 (1942).

145. 351 U.S. 192 (1956).

146. 181 F.2d 796 (1950).

147. $181 \mathrm{~F} .2 \mathrm{~d}$ at 798 .

148. Id. at 799 . 
similar ruling under the Civil Aeronautics $\mathrm{Act}^{140}$ and has frequently been cited since, most recently by the Third Circuit in holding a newly promulgated regulation of the Securities and Exchange Commission (SEC) not an "order" directly reviewable in the court of appeals. ${ }^{150}$ As a result of such reasoning, the avenue for pre-enforcement review of regulations, even of those promulgated by agencies whose final adjudicative orders go directly to an appellate court, is often an action for injunction or declaration under general jurisdictional provisions in a district court. ${ }^{151}$ This is, of course, the avenue for pre-enforcement challenges to the constitutionality of statutes. In fact, early decisions, influenced no doubt by the quasi-legislative nature of administrative regulations, tended to treat them like statutes for purposes of judicial review. ${ }^{162}$

The United Gas Pipe rationale is in decline, however, both legislatively and judicially. In recent years, Congress, building on the precedent of price regulation during the Second World War, ${ }^{163}$ has expressly authorized direct circuit court review of agency regulations in such fields as automotive and consumer-products safety, occupational health, water and air pollution, and noise. ${ }^{154}$ The court that decided United Gas Pipe, having now undertaken direct review of regulations of both the $\mathrm{FPC}^{155}$ and the $\mathrm{CAB},{ }^{160}$ has redefined its position: United Gas Pipe "has not been followed . . . where evidence has been assembled before the agency and is not challenged, and where the issues presented are legal and not factual." 157 In such a case, there is "no need to have the matter adjudicated at the district court level in order to have an appropriate record compiled. It is the availability of a record for review and not the holding of a quasi judicial hearing which is now the jurisdictional touchstone." ${ }^{158}$ The author of United Gas Pipe, Chief Judge Bazelon, noting

149. Pub. L. No. 85-791, § 18, 72 Stat. 947 (1958); Arrow Airways v. CAB, 182 F.2d 705 (D.C. Cir. 1950).

150. PBW Stock Exchange, Inc. v. SEC, 485 F.2d 718 (3d Cir. 1973), cert. denicd, 416 U.S. 969 (1974). The American Law Institute's FEDERAL SECuRITIEs Code would reverse the result in the $P B W$ case by providing for direct circuit court review not only of a "final order" but also of "other final action" of the SEC, including rules. ALI FEDERAL SeCurities Code \& 1415(a) (Tent. Draft No. 3, 1974). See also S. 2519, \& 6(a), 93d Cong., 1st Sess. (1974) (SEC regulations approving, disapproving, or modifying rules of exchanges would be treated as "orders" and thus be reviewable in the courts of appeals).

151. See, e.g., Abbott Laboratories, Inc. v. Gardner, 387 U.S. 136 (1967) (Food and Drug Administration). Similarly, in Canada it is only "quasi-judicial" as opposed to "administrative" orders that are reviewed directly in the appellate court. Federal Court Act 1970, 19 Eliz. 2, c. 1, § 28.

152. See, e.g., Pacific States Box \& Basket Co. v. White, 296 U.S. 176 (1935).

153. Emergency Price Control Act of 1942, ch. 26, tit. II, \& 204, 56 Stat. 31 (i942).

154. 15 U.S.C. $\$ 1394$ (1970) (automotive safety); id. \& 2060 (consumer products safety); 29 U.S.C. $\$ 655$ (f) (1970) (occupational health and safety); 33 U.S.C. \& 1369 (b) (1970) (water pollution); 42 U.S.C. $\$ \$ 1857 \mathrm{~h}-5$ (b) (1970) (air pollution); id. \& 4915 (a) (noise). See also note 150 supra.

155. City of Chicago v. FPC, 458 F.2d 731, 740-41 (D.C. Cir. 1971) ; New England Power Co. v. FPC, 467 F.2d 425 (D.C. Cir. 1972). The Supreme Court passed on the merits in the latter case without adverting to the issue of direct review, FPC v. New England Power Co., 415 U.S. 345 (1974).

156. Deutsche Iufthansa Aktiengesellschaft v. CAB, 479 F.2d 912 (D.C. Cir. 1973).

157. Id. at 915-16.

158. Id. at 916 . 
Professor Jaffe's criticism that the decision divided review of a single agency between trial and appellate courts, has now abandoned it altogether. ${ }^{159}$

Most recently, however, doubts have been raised once again about the appropriateness of direct appellate review of informal rulemaking. Concurring in Texas $v$. EPA, ${ }^{160}$ a challenge to the regulations for implementing airquality standards in Texas, Judge Clark of the Fifth Circuit protested "the adverse effects flowing from the legislative mandate that judicial review proceedings be injected into the court system at the appellate level." ${ }^{161} \mathrm{He}$ explained:

No formal hearing has ever been held in this highly technical, factually complex matter. The administrative "record" upon which we had to base our review was comprised of only the sparsest of documentation, for it essentially evolved from an act of agency rulemaking. . . . The writing judge was required to hold both pre- and post-argument conferences with counsel for the parties to enable the three of us as a court to comprehend the substance of the issues and conduct a minimally meaningful review.

The subject matter of this action involves the health and welfare of millions of citizens, the continued business vitality of tens of thousands of firms and compliance expenditures costing billions of dollars.

These extensive rights deserve a more orderly process of judicial reflection. ${ }^{162}$

Judge Clark did not further specify what judicial processes would be more orderly or otherwise more appropriate.

Still more recently, the First Circuit in South Terminal Corp. v. EP $A^{183}$ lamented that upon direct review the only way to obtain additional information as to facts not adequately established in a rulemaking proceeding is to remand to the agency: "The normal way courts evaluate a technical issue is through proceedings attended by expert witnesses."104

2. Appraisal of Need for Appellate Court Factfinding. Whether direct appellate review of informal rulemaking makes good sense depends in the first instance upon whether United Gas Pipe was correct in its perception that the need for judicial trial of the facts renders the appeals court an inappropriate forum. When regulations are required to be based upon a trialtype administrative record, as in the widely criticized Food and Drug

159. Environmental Defense Fund, Inc. v. Hardin, 428 F.2d 1093, 1098-99 \& n.27 (D.C. Cir. 1970) (Bazelon, J.) (dictum), citing L. JAFFE, supra note 4, at 423 .

160. 499 F.2d 289 (5th Cir. 1974).

161. Id. at 321 .

162. Id. at $321-22$.

163. 504 F.2d 646 (1st Cir. 1974).

164. Id. at 665-66. See also 52 TEXAS I. REv. 1014, 1021 (1974) (district court was a preferable forum for reviewing the SEC regulation challenged in PBW Stock Exchange, Inc. v. SEC, 485 F.2d 718 (3d Cir. 1973), cert. denied, 416 U.S. 969 (1974), "because the case raises factual issues [such as 'the rule's potential anticompetitive effects'] that can be more efficiently determined in a trial court"). 
Administration procedure, ${ }^{165}$ facts relevant to the validity of the regulation present no problem: Validity is determined on the administrative record. More commonly, however, regulations are adopted after notice and opportunity for comment, with no express APA requirement that the agency base its action on the record. ${ }^{168}$ It is therefore conceivable that a judicial hearing may be necessary to elicit facts bearing upon the question of validity.

The scope of judicial review of informal rulemaking is currently a matter of interesting debate. ${ }^{107}$ Except where the agency is required to decide on a record, the APA limits review generally to such "legal" questions as whether agency action is within statutory authority or is "arbitrary."108 At least one circuit court has held that the sole test of validity was "whether on the factual premise upon which the Commission acted" the rule adopted was arbitrary, for "if the factual premise itself were open to review, then it would be necessary for all general rule-making to include a trial-like hearing."100

If the factual premises underlying a regulation are unchallengeable in court, there is obviously no need for a trial to determine their correctness. This approach, however, is clearly in disfavor, and properly so. Statutory authority, though a "legal" question, is often dependent upon the existence of certain facts. In Citizens to Preserve Overton Park, Inc. v. Volpe, , $^{170}$ for example, the administrator was authorized to approve federal funding of a highway through a park only if there was no "feasible and prudent alternative."171 The Court said a reviewing tribunal must determine "that the Secretary could have reasonably believed that in this case there are no feasible alternatives."172 The further "legal" guarantee against arbitrariness similarly demands a factual investigation: It requires, according to Overton Park, a court to determine whether an administrator's decision was "based on a consideration of the relevant factors and whether there has been a clear error of judgment."173 These criteria, although enunciated in the context of informal adjudication, are equally appropriate in review of regulations, and they have

165. 21 U.S.C. \& 371(e) (1970). See Hamilton, Procedures for the Adoption of Rules of General Applicability: The Need for Procedural Innovation in Administrative Rulemaking, 60 CALIF. L. REV. 1276 (1972).

166. 5 U.S.C. $\& 553(1970)$. (1974).

167. See Verkuil, Judicial Review of Informal Rulemaking, 60 VA. L. REv, 185

168. 5 U.S.C. $\S 706(1970)$.

169. Superior Oil Co. v. FPC, 322 F.2d 601, 619 (9th Cir. 1963). The court in Superior Oil relied upon the leading case of Pacific States Box \& Basket Co. v. White, 296 U.S. 176 (1935), where Mr. Justice Brandeis had written that if "any conceivable state of facts" would make a state regulation valid, those facts should be presumed to exist. But Pacific States Box did not hold the presumption irrebuttable; it merely held that it was not overcome by general allegations that the regulation served no valid purpose.

170. 401 U.S. 402 (1971).

171. Id. at 405 .

172. Id. at 416 .

173. $I d$. 
been widely applied in such cases. ${ }^{174}$ We do not see how a court, without delving into the facts, can responsibly determine whether or not a regulation meets a statutory requirement that emission standards be "achievable" by control systems that have been "adequately demonstrated,"175 or whether a motor vehicle safety standard is "practicable" and meets "the need for motor vehicle safety."178

To say that courts should and increasingly do scrutinize the factual support for regulations does not imply, however, that the relevant facts must be developed in court, much less by an evidentiary trial. The Office of Price Administration (OPA) legislation, for example, initially interposed before appellate court review an administrative appeal in which a full hearing could be had on any relevant facts. ${ }^{177}$ More significantly, while other direct-review statutes contain no comparable provisions, courts of appeals are increasingly finding ways to base their factual scrutiny of regulations on materials that were in some manner brought out before the rulemaking agency.

The Occupational Safety and Health Act (OSHA), for example, makes this construction easy. Although it does not require the Department of Labor to conduct a trial-type hearing, ${ }^{178}$ it explicitly makes the Secretary's deter-

174. See, e.g., Portland Cement Ass'n v. Ruckelshaus, 486 F.2d 375, 402 (D.C. Cir. 1973), cert. devicd sub nont. Portland Cement Corp. v. Administrator, 417 U.S. 921 (1974). See also City of Chicago v. FPC, 458 F.2d 731, 742 (D.C. Cir. 1971) ("[I]t makes little sense to require that the legislature articulate intelligible standards to govern agency action if realistic inquiry into whether those standards are being followed were foreclosed.").

175. Sec Portland Cement Ass'n v. Ruckelshaus, 486 F.2d 375 (D.C. Cir. 1973), ccrt. dcnicd sub nom. Portland Cement Corp. v. Administrator, 417 U.S. 921 (1974).

176. Sec Chrysler Corp. v. Department of Transp., 472 F.2d 659 (6th Cir. 1972).

177. Emergency Price Control Act of 1942, ch. 26, tit. II, $\$ \S 203-04,56$ Stat. 31 (1942). A later amendment authorized the Emergency Court of Appeals (ECA) to pass on regulations, following entry of a civil or criminal judgment, without prior administrative hearing, but allowed a reference to the Administrator in such cases in lieu of a court trial. Act of June 30, 1944, ch. 325, tit. II, \$ 107, 58 Stat. 639; see ECA R. 18, following $i d . \S 107$, providing that upon satisfactory offer of proof the court might refer to the Administrator or hear the facts itself by depositions, interrogatories, affidavits, or "in open court." Section 204(c) gave the ECA, sitting in panels of three or more, the "powers of a district court" except that no preliminary relief against price regulations could be granted. Ch. 26, tit. II, $\$ 204$ (c), 56 Stat. 32 .

178. Under 29 U.S.C. $\$ 655^{\prime}$ (b) (3) (1970), the Secretary upon request must afford a "public hearing" on the proposed standards. Provisions in the same section that he designate "a time and place" for the hearing, and that the request be made during "the period provided for the submission of written comments," preclude reading the hearing requirement as satisfied by informal notice-and-comment procedure, as the Supreme Court held with respect to the Interstate Commerce Act, 49 U.S.C. \& 1(14) (a) (1970) (ICC freight-car allocation regulations) in United States v. Florida East Coast Ry., 410 U.S. 224 (1973). At the same time, however, the abandonment of an earlier House bill provision that would have required a trial-type hearing has led two circuit courts understandably to the conclusion that the hearing required is only a "legislative" one (not a quasi-judicial trial) characterized by speechmaking in support of or against the proposed regulation. Associated Indus. of N.Y.S., Inc. v. Department of Labor, 487 F.2d 342, 348-49 (2d Cir. 1973); Industrial Union "Dep't, AFL-CIO v. Hodgson, 499 F.2d 467, 474 (D.C. Cir. 1974). Both courts, however, required that the Department's regulations be based on the "record." 487 F.2d at $349 ; 499$ F.2d at 475-76. In order to facilitate the compilation of such a "record," the Department has modified its procedures to allow, for example, some cross-examination. 29 C.F.R. § 1911.15 (1973). 
minations underlying a regulation "conclusive if supported by substantial evidence in the record considered as a whole."170 This provision, the Second Circuit has held, imposes "some responsibility on the part of the Department to explain and support the proposals it is advancing, at least when these have been opposed on substantial grounds." 180 Since the statute does not make clear that the "record" that must support the regulation is the record made before the agency, it might be read as allowing new factual material to be presented in court. In accordance with the usual meaning of the term, however, the Department of Labor by regulation construed the statute-correctly, according to the Second Circuit ${ }^{181}$ - to require that the rulemaking itself be done "on the basis of a record to which a substantial evidence test . . . may be applied."182 Thus, in remanding for want of record support, the court insisted that the Department should have presented "at the outset of the hearing some justification" for its proposed regulation. ${ }^{183}$ The District of Columbia Circuit, while concluding that policy, as opposed to factual, determinations do not lend themselves to evaluation in light of evidence, agreed that the statute requires the Secretary to make factual decisions on the record before him, and judicial review is to be based on that record. ${ }^{184}$

Even statutes less explicit than OSHA have been construed by some circuit courts to impose the same requirement. The National Traffic and Motor Vehicle Safety Act is silent as to hearings, ${ }^{185}$ and it says nothing about the standard of review. Yet it does require filing in the circuit court of the "record" on which the order setting the standard was "based." 180 The Sixth Circuit has read this requirement to mean that review is to be on the basis of that record and that the "substantial evidence" test applies. ${ }^{187}$

179. 29 U.S.C. \& 655(f) (1970).

180. Associated Indus. of N.Y.S., Inc. v. Department of Labor, 487 F.2d 342, 351 (2d Cir. 1973).

181. Id. at 349 .

182. Id.

183. Id. at 351.

184. What we are entitled to at all events is a careful identification by the Secretary, when his proposed standards are challenged, of the reasons why he chooses to follow one course rather than another. Where that choice purports to be based on the existence of certain determinable facts, the Secretary must, in form as well as substance, find those facts from evidence in the record. . .

Industrial Union Dep't, AFL-CIO v. Hodgson, 499 F.2d 467, 475-76 (D.C. Cir. 1974). 185. 15 U.S.C. $\S 1392$ (b) (1970) provides only that safety standards shall be adopted in accord with the Administrative Procedure Act, which in the absence of specific statutory direction requires only notice and comment, 5 U.S.C. \& 553 (1970). Sce Automotive Parts \& Accessories Ass'n v. Boyd, 407 F.2d 330 (D.C. Cir. 1968) (upholding informal rulemaking).

186. 15 U.S.C. \& 1394(a) (1970).

187. Clearly when factual issues are involved, including the issue of whether compliance is technologically feasible, the reviewing court must consider the record upon which the Agency based its order. ... [A]ny rule which is required to be, inter alia, "practicable" and "objective" must be reviewed on the basis of the data which the Agency considered in its promulgation, regardless of whether formal hearings were or were not held.

Chrysler Corp. v. Department of Transp., 472 F.2d 659, 668 (6th Cir. 1972). But sce Boating Industry Ass'n v. Boyd, 409 F.2d 408, 411 (7th Cir. 1969) (rejecting applica- 
The Clean Air Act ${ }^{188}$ is devoid of any suggestion that judicial review of Environmental Protection Agency (EPA) regulations is to be based upon material that was before the Administrator. Yet in remanding an emission standard to the agency for inadequate disclosure of the basis for its initial proposal, the District of Columbia Circuit has gone a long way toward so holding. Regulations, wrote Judge Leventhal in Portland Cement Ass'n v. Ruckelshaus, ${ }^{189}$ may not be promulgated on inadequate data

or on data that, to a critical degree, is known oniy to the agency .... . [I]nformation should generally be disclosed as to the basis of a proposed rule at the time of issuance [and court challenges must generally be] limited to points made by petitioners in agency proceedings. ${ }^{130}$

None of these decisions squarely rejects an effort to bring before the court factual information that was not made a matter of record before the agency, for in none was that the issue. Yet the clear trend of such decisions is to base judicial review upon an administrative record, despite the absence of a trial-type hearing. If such is the law, there is no need for a judicial trial of facts relating to validity.

This view of the reviewing function derives support from Mr. Justice Frankfurter's opinion for the Supreme Court in National Broadcasting Co., Inc. v. United States, ${ }^{191}$ affirming the decision of a three-judge district court upholding FCC chain-broadcasting regulations as adopted. Not only does the opinion state that "[o]ur duty is at an end when we find that the action of the Commission was based upon findings supported by evidence,"192 but it goes on explicitly to say that matters not before the FCC should not be considered:

The court below correctly held that its inquiry was limited to review of the evidence before the Commission. Trial de novo of the matters heard by the Commission and dealt with in its Report would have been improper. ${ }^{193}$

Yet it would be too hasty to conclude that materials not placed in the record before the rulemaking agency may never be produced in court. The Consumer Product Safety Act, for example, though requiring that the Commission file the "record of proceedings" on which it "based its rule" and providing that Commission findings be upheld only if supported by "substantial evidence on the record taken as a whole," goes on to define the

tion of the "substantial evidence" test to vehicle-safety standards because the statute does not require an agency hearing).

188. 42 U.S.C. \& 1857 (Supp. III, 1973).

189. 486 F.2d 375 (D.C. Cir. 1973).

190. Id. at 393-94.

191. 319 U.S. 190 (1943).

192. Id. at 224 .

193. Id. at 227 . 
"record" to include not only such matters as the notice of proposed rulemaking and the comments received, but also "any other information which the Commission considers relevant to such rule."194 This appears to embrace material not made public during the rulemaking proceedings and even, perhaps, material not considered by the agency in adopting the rule. Similarly, the Administrative Conference has recommended that the record on review of informal rulemaking include factual information not elsewhere included in the record "that was considered by the authority responsible for promulgation of the rule or that is proffered by the agency as pertinent to the rule."105 And the First Circuit in South Terminal Corp. v. EPA ${ }^{\mathbf{1 0 6}}$ recently indicated that additional material would sometimes be appropriate for introduction at the judicial review stage.

If factual material may be presented for the first time in court, fairness surely demands that affected persons have an opportunity for rebuttal, either in court or before the agency, and neither alternative is very palatable. For the reviewing court to accept rebutting information and to make its own decision based upon material not considered by the rulemaking agency, as suggested in South Terminal, ${ }^{107}$ would hardly be consistent with the statutory command that the agency make the regulations. What the Supreme Court said in refusing to allow new evidence in court upon review of a rate order seems equally applicable here: "To allow [the] ... findings to be attacked or supported in court by new evidence would substitute the court for the administrative tribunal as the rate making [or rulemaking] body."198 The alternative is a time-consuming remand to the agency for additional input. ${ }^{190}$

194. 15 U.S.C. \& 2060 (1970).

195. ACUS Rec. 74-4, supra note 104, at I 1(4) (adopted May, 1974). The supporting memorandum of the Committee on Judicial Review would limit material not coisidered by the agency to that "becoming available after the decision to promulgate the rule was made," and asserts that the recommendation does not decide whether the reviewing court should be "limited to the information before the agency." Committee on Judicial Review, Administrative Conference of the U.S., Supporting Mcmorandum Re ACUS Rec. 74-4. II 1(4), May, 1974. See also Chrysler Corp. v. Department of Transp., 472 F.2d 659, 669 (6th Cir. 1972) (record on review for purposes of National Traffic and Motor Vehicle Safety Act, 15 U.S.C. \& 1392(b) (1970) includes "the technological and statistical data relied upon by the Agency in arriving at its conclusions").

The Administrative Conference has adopted somewhat contradictory positions with respect to what constitutes the record for review. Nothwithstanding its recommendation for broad definition of the record on review, it agrees that in notice-and-comment rulcmaking an agency "to the extent feasible" should "make available documents, materials and public submission upon which the proposed rule is based." 2 ACUS Rec. 71-6, supra note 104, at 35 (1970-72). Contrast the Conference's retrograde Recommendation 72-5. 2 id. at 66 , that "in future grants of rulemaking authority ...., Congress ordinarily should not impose mandatory procedural requirements other than those required by 5 U.S.C. \& 553." Partial reconciliation, probably unintended by the Conference, would result from making clear that Portland Cencint interprets rather than adds to $\$ 553$ : perhaps it is time the Conference gave the whole problem a fresh look.

196. 504 F.2d 646, 665 (1st Cir. 1974).

197. Id. at $665-66$.

198. Tagg Bros. v. United States, 280 U.S. 420, 444 (1930) (Brandeis, J.), cited approvingly in NBC v. United States, 319 U.S. 190, 227 (1943) (a rulemaking case).

199. This is clearly contemplated by the Consumer Product Safety Act. The statute 
A requirement that rules adopted by an administrative agency be supported by a public record developed in a notice-and-comment proceeding would, of course, depart markedly from the analogy of legislative enactment. ${ }^{200}$ While it seems difficult to deny that the development and rebuttal of a factual case to support proposed legislation would often be likely to improve the product, we think the situations distinguishable. It is traditionally acceptable for legislatures, not composed of technical experts, to act informally in the exercise of a judgment essentially more political than factual, to accommodate the clashing interests of diverse groups. The very purpose of statutory delegation to a specialized and expert agency, however, is to obtain a more professional, less political judgment. The statutes emphasize this purpose by laying down standards, often technically exacting, to govern the exercise of rulemaking power, and by imposing procedural formalities-notice, comment and a concise statement of reasons - that are not applicable to the legislature itself. The judicial impulse to convert informal rulemaking into what might be called semi-formal rulemaking-more accurately, rulemaking based upon a record developed through somewhat structured dialogue between the agency and the affected parties-can be viewed as an effort to make the statutory opportunity for comment a meaningful one in light of the statutory purpose. Moreover, significant procedural differences may be dictated by the sheer difference in size between the two decisionmaking bodies. It would obviously not be feasible to demand that a legislature of several hundred members adopt even

provides for remand when "the petitioner applies to the court for leave to adduce additional data .... and shows .... that there were reasonable grounds for the petitioner's failure to adduce such data . . . in the proceeding before the Commission . . . 15 U.S.C. $\$ 2060$ (b) (1970). See Scalia \& Goodman, Procedural Aspects of the Consumer Product Safety Act, 20 U.C.L.A. L. REv. 899, 923, 936 n.144 (1973).

The Environmental Protection Agency, stressing that a remand to counter agency information disclosed for the first time in court may postpone the effective date of important regulations, argued against a loose definition of "record" proposed by the Administrative Conference, see note 195 and accompanying text supra. Requiring disclosure of agency support material during the rulemaking proceeding and limiting the record essentially to matters so disclosed will, the EPA argued, "improv[e] the process of informal rulemaking itself and lessen ... the need for judicial review" by "facilitating timely and informed comment and increasing the likelihood that hard problems will be addressed before final promulgation," rather than "on remand from a reviewing court." The EPA memorandum, moreover, endorsed the requirements imposed upon it in the Portland Cement case: "There seems to be no adequate justification for revealing such material only at the time of final promulgation (much less at the time the record for review is compiled)." EPA, Comments on Proposed ACUS Rec. 74-4, ๆ 1(4): PreenForcenient Judicial Review of Rules of General Applicability 14, 22 (1974). Most dramatically, the EPA has integrated the Portland Cement procedure into its practice for adoption of effluent guidelines under the water pollution statute, 33 U.S.C. $\S \S$ 1251-92. 1311-28, 1341-45, 1361-76 (Supp. III, 1973). See 38 Fed. Reg. 21202-06 (1973).

Even if the Administrative Conference gets its way and an agency is permitted to bring before the court new factual material, the desirability of avoiding a remand may discourage remands in any case. See Scalia \& Goodman, supra note 199, at 923.

200. See Williams, Judicial Compulsion of Procedures Not Required by Section 553 in "Notice-and-Comment" Rulemaking 55-56 (1974) (unpublished draft submitted to the Administrative Conference of the United States): "It seems appropriate that the same device employed (where necessary) to verify the factual underpinnings of legislative acts should be available for a court to verify the factual support of agency rules . ..." 
the "concise general statement" of reasons that the APA requires of rulemaking agencies. Finally, the constitutional dignity of the legislature, its broad-based mandate from, and closeness to, the sovereign electorate, and above all the immediate political checks on irresponsible legislation make tolerable a procedural looseness in Congress that would be less acceptable in an administrative agency.

A requirement that a public record be developed to support rules promulgated by an administrative agency should not, however, be taken to require trial-type hearings for rulemaking. The agency must simply make public its supporting factual information in time for rebuttal; the method of presentation is an entirely separate question.

This requirement may, however, invest rulemaking proceedings with a degree of finality more common to quasi-judicial decisions. Carried to the extreme of requiring challenges within a short period, as in the Clean Air Act, ${ }^{201}$ finality can easily cut off important rights of unsuspecting persons-a danger much reduced in adjudication because only the parties are bound. We see similar dangers in limiting review of regulations to persons who participated in the rulemaking proceedings; there is no justification in policy for holding that persons not so participating can only sue in a district court, ${ }^{202}$ so long as review is, as we have advocated, limited to the administrative record. Even this limit may cut off legitimate claims that could not reasonably have been anticipated; but if the preservation of reasonably unanticipated claims is thought to justify allowing reexamination of regulations on the basis of new information, we think it more consistent with the theory of delegated rulemaking that the clata be first presented, and the initial reassessment made, in the rulemaking agency, not in court.

Further, even under the Consumer Product Safety Act, ${ }^{203}$ where the agency may bring before the court materials it did not earlier make public, there may be no need for taking evidence in court as to the validity of a regulation. That statute, in the first place, speaks of "filing" such material as a part of the record, just as if it had been introduced formally before the agency; it does not contemplate presentation by witnesses in open court. And if a party challenging the regulation wishes to rebut the new material, the statute envisions a remand to the agency, not a judicial trial. ${ }^{204}$

Finally, apart from such specific statutory language, the traditional distinction between "legislative" and "adjudicative" facts suggests that oral testi-

201. 42 U.S.C. \& 1857h-5(b) (Supp. III, 1973).

202. See Gage v. AEC, 479 F.2d 1214 (D.C. Cir. 1973), construing the Hobbs Act, 28 U.S.C. $\$ 2344$ (1970), which allows direct circuit court review by a "party" to a proceeding made reviewable by the Atomic Energy Act, 42 U.S.C. $\$ 2239$ (1970), which in turn includes regulations.

203. 15 U.S.C. \$§ 2051-81 (Supp. III, 1973).

204. See note 199 supra. 
mony will not be the standard method of presentation if a court accepts new factual material respecting the validity of a regulation. Professor Davis has stated:

Adjudicative facts are the facts about the parties and their activities, businesses, and properties. . . . Legislative facts do not usually concern the immediate parties but are general facts which help the tribunal decide questions of law and policy and discretion. . . .

... Because the parties may often have little or nothing to contribute to the development of legislative facts, the method of trial often is not required for the determination of disputed issues about legislative facts.

... and should not be required.205

The facts upon which regulations of general applicability are based are likely to be legislative facts in this sense. Professor Karst has forcefully argued for more attention to adequate presentation of legislative facts in constitutional cases and has cited instances in which such matters were established by evidence at trial. ${ }^{200}$ The First Circuit's dictum in South Terminal indicates that such a presentation would be proper in district court review of a regulation. Yet as Karst points out, it is common practice to establish legislative facts in court, when they are not simply noticed by the court on its own, through such informal means as affidavits or Brandeis briefs. It would hardly be surprising if the same were done with legislative facts in rulemaking cases, especially since no trial is usually required for development of such issues before the agency itself.

The foregoing survey of judicial review of informal rulenaking suggests that the absence of a trial-type record may not present as substantial an obstacle to direct court of appeals review as might appear at first blush. Often the sole issues will involve pure statutory construction. Sometimes a court may still adhere to the old-fashioned view that it may not inquire into the facts. Increasingly, we believe, factual matters will be determined on the basis of material that was before the agency. And if new matter is allowed, it seems likely to be presented either as a part of the "record" relied on below, or before the agency on remand, or as legislative fact in the form of a Brandeis brief. We do not say the occasion for taking evidence in court will never arise. ${ }^{207}$

205. K. Davis, Administrative Law Text, § 7.03, at 160 (3d ed. 1972).

206. Karst, Legislative Facts in Constitutional Litigation, 1960 Sup. Cт. Rev. 75. For additional examples, see Williams, supra note 200 , at 55 .

207. In at least one case under the Emergency Price Control Act of 1942, Ch. 26, tit. II, 56 Stat. 31, the Emergency Court of Appeals, after an initial administrative review hearing and not one but two remands, itself heard additional evidence bearing on the validity of a regulation. Heinz v. Bowles, 149 F.2d 277 (Emer. Ct. App. 1945). And in Texas v. EPA, 499 F.2d 289 (5th Cir. 1974) a single member of the appellate panel conducted conferences with counsel to straighten out matters of fact. Professor Steven Williams has called attention to an old Supreme Court case, Houston v. St. Louis Independent Packing Co., 249 U.S. 479 (1919), cited in Williams, supra note 200, at 53-54, in which the validity of a regulation was determined on the basis of court testimony.

Professor Williams has also noted some pieces of legislative history suggesting that 
But on the strength of our examination to date, we think such occasions may be the exception rather than the rule. When they occur they can be dealt with in a variety of ways short of a cumbersome trial before three judges: by conferences as in Texas v. EPA, ${ }^{208}$ by a hearing before a master ${ }^{200}$ or perhaps before a single circuit judge, ${ }^{210}$ by remand to the agency, or, statute permitting, by transfer to a district court for liearing. ${ }^{211}$ Admittedly, any of these procedures would be burdensome in the particular case. If we are right, however, that they will rarely be necessary, it would seem unfortunate to sacrifice the obvious economies of direct review in the many manageable cases in order to avoid an occasional burden.

There are, however, further complications respecting the possible need for judicial factfinding in review of informal rulemaking. First, for reasons noted in connection with review of adjudication, factual issues relating to motions for interim relief can be handled by requiring the agency to pass first upon such motions, or by reference to a master, or by summary proceedings before the appellate court itself. ${ }^{212}$ Second, although facts outside the agency record may be relevant to a determination of standing, ${ }^{213}$ an issue largely foreign to review of quasi-judicial orders, the usual dispute, one suspects, concerns not the

Congress in enacting the APA contemplated judicial evidence-taking as a matter of course to determine the validity of non-record regulations:

Where a rule or order is not required by statute to be made after opportunity for agency hearing and to be reviewed solely upon the record thereof, the facts pertinent to any relevant question of law must be tried and determined de novo by the reviewing court respecting either the validity or application of such rule or order-because facts necessary to the determination of any relevant question of law must be determined of record somewhere and, if Congress has not provided that an agency shall do so, then the record must be made in court.

H.R. REP. No. 1980, 79th Cong., 2d Sess. (1946), quoted in Williams, supra note 200, at 52. See also S. REP. No. 572, 79th Cong., 1st Sess. (1945). This statement purported to explain 5 U.S.C. \& 706(2) (f) (1970), which provides in relevant part:

The reviewing court shall ... set aside agency action, findings and conclusions

found to be ... unwarranted by the facts to the extent the facts are subject to trial de novo by the reviewing court.

Regardless of the committee's intention, this provision appears not to prescribe when a trial is to be had, but only, to indicate the scope of review when some other law prescribes trial de novo. In any case, the imposition of procedural requirements looking toward development of a non-adjudicative record, as in the Portland Cement case, has substantially undermined the premise of the committee position, and Professor Willian1s affirms "the apparent rarity of judicial trial" of facts relating to validity. Williams, supra note 200 , at 55 .

208. 499 F.2d 289 (5th Cir. 1974).

209. For the comparable problem of ascertaining facts in a proceeding for contempt in the court of appeals, see notes 41-51 and accompanying text supra.

210. Unlike the three-judge district court, 28 U.S.C. $\$ 2284$ (1970), the circuit court is not clearly disabled by statute from delegating the evidence-taking function to a single judge. But see id. § 46(b) (authorizing "hearing" as well as "determinations" of cases by three circuit judges). Cf. Texas v. EPA, 499 F.2d 289 (5th Cir. 1974).

211. 28 U.S.C. \& 2347 (1970) ("when a hearing is not required by law and a genuine issue of material fact is presented"). The same section authorizes a reference to the agency for additional evidence where there are "reasonable grounds for failure to adduce the evidence before the agency."

212. See notes $41-51$ and accompanying text supra.

213. Cf. SCRAP v. United States, 412 U.S. 669 (1973). 
extent of the plaintiff's interest but its legal sufficiency, a subject for argument not proof.

More important, the discussion so far has assumed that the regulation is attacked on its face, while it may be possible for an affected person to challenge the validity of a regulation as applied to his individual situation. ${ }^{214}$ Individualized facts-for example, the absence of space at the petitioner's plant to install a pollution-control device-are not likely to have been brought-before the agency; it would be cumbersome to provide a hearing on all such questions within the rulemaking process. Moreover, the facts giving rise to a claim of individual hardship are almost by definition "adjudicative" rather than "legislative," so that a trial-type hearing-such as is seldom afforded in rulemaking -may be constitutionally required.15 One court has concluded that such challenges may be brought in a court of appeals, ${ }^{216}$ another court, noting the impracticability of providing an adequate hearing on individual claims during rulemaking, disagreed. ${ }^{217}$ If this latter view prevails, review of agency regulations will be bifurcated: Facial validity will be determined by the circuit courts, validity as applied by the district courts.

That neither the rulemaking process nor the appellate court is wellequipped to determine the facts bearing on applicability of a regulation to individual cases seems manifest; the practical significance of this problem in determining the appropriate forum for judicial review, however, is less clear. Truly individualized facts should as a matter of statutory construction rarely render a regulation invalid as applied: The very purpose of a regulation is to avoid the necessity of determining the appropriate rule on a case-by-case basis. Section 111 of the Clean Air Act, for instance, prescribes that new-source performance standards "reflect the degree of emission limitation achievable through the application of the best system of emission reduction which (taking into account the cost of achieving such reduction) the Administrator determines has been adequately demonstrated." 218 One would hardly expect the EPA to make a plant-by-plant determination as to the best practicable control technology in setting such a standard. ${ }^{219}$ On the other hand, determining

214. Getty Oil Co. v. Ruckelshaus, 342 F. Supp. 1006 (D. Del. 1972), rev'd in part on other grounds, 467 F.2d 349 (3d Cir. 1972) ; Buckeye Power, Inc. v. EPA, 481 F.2d 162, 173 (6th Cir. 1973); Gage v. AEC, 479 F.2d 1214, 1218-19 (D.C. Cir. 1973).

215. See Londoner v. Denver, 210 U.S. 373 (1908).

216. Getty Oil Co. v. Ruckelshaus, 324 F. Supp. 1006 (D. Del. 1972).

217. Buckeye Power, Inc. v. EPA, 481 F.2d 162, 173 (6th Cir. 1973).

218. 42 U.S.C. \& 1857 c-6(a) (1) (Supp. III, 1973).

219. Cf. Heinz v. Bowles, 149 F.2d 277, 281 (Emer. Ct. App. 1945), where the court interpreted a statute requiring maximum prices to be "generally fair and equitable":

If the price enabled most of the non-processing slaughterers to operate profitably, the regulation would not be rendered invalid by the fact that an occasional marginal producer in the group could not stay in business under the established ceilings.

Indeed, when individual hardship is deemed to excuse one from compliance, statutes commonly provide a quasi-judicial variance procedure in which the expert agency may 
whether whole classes of emission sources require separate treatment ${ }^{220}$ involves legislative facts and is the very sort of question with which the rulemaking process is designed to deal. Thus, the danger that individual facts may have to be established in a court of appeals to determine the validity of a regulation as applied may be more theoretical than real; many such contentions can appropriately be disposed of by the equivalent of a demurrer without trial.

In short, unless the court takes what we think would be the unusual and misguided step of allowing new factual evidence on the issue of facial validity, the occasions for factfinding in pre-enforcement review even of informal rulemaking seem likely to be relatively minor. We are strengthened in this conclusion by the fact that the agencies responding to our questionnaire report that direct review of regulations has caused no practical problems. ${ }^{221}$ If other considerations cut strongly in favor of direct appellate review of such regulations, it may be inappropriate to let the tail wag the dog by requiring a trial court forum rather than allowing a modicum of awkwardness at the appellate level.

The most compelling argument for bypassing the trial courts in rulemaking cases is that regulations of general applicability, almost by definition, are relatively more significant than individual adjudications. Affecting often an entire industry or class of persons, the question of the validity of such regulations is quite likely to end up in a court of appeals anyway. Unless factfinding requirements substantially discommode the circuit courts, it makes sense to avoid the delay and expense of prior district court litigation. ${ }^{222}$ This

determine the facts. E.g., 42 U.S.C. $\S 1857 \mathrm{c}-5$ (f) (Supp. III, 1973) (air pollution). Exhaustion of such an administrative remedy should perhaps be a prerequisite to judicial attack on a regulation as applied. See Commonwealth Edison Co. v. Pollution Control Bd., Ill. App. 3d NE.2d (1st Dist, 1974) (limiting direct appellate review of regulations to questions of facial validity: confining individual hardship cases to seeking variances from the agency).

220. E.g., Heinz v. Bowles, 149 F.2d 277, 281 (Emer. Ct. App. 1945) (invalidating application of meat-price regulation to non-processing slaughterers because "a common economic situation... sets them apart from the rest of the industry").

221. See letters to Antonin Scalia, Chairman of the Administrative Conference from General Counsel Office of the AEC, Oct. 7, 1974, Dep't of Transportation (highway safety), Oct. 30, 1974, and Consumer Product Safety Commission, Nov. 18, 1974. As the $C A B$ has pointed out, circuit courts sometimes must review the validity of regulations without benefit of district court factfinding when regulations are challenged on appeal from a quasi-judicial enforcement order. See letter from Thomas J. Heye, CAB General Counsel, to Antonin Scalia, Chairman of Administrative Conference, Oct. 18, 1974, citing Great Lakes Airlines, Inc. v. CAB, 291 F.2d 354, 367 (9th Cir. 1961) (the agency's trial examiner had excluded evidence going to the validity of the regulations; the court said that if facts were necessary a remand would be in order but held the regulations valid as a matter of law).

222. The $\mathrm{CAB}$, arguing that "interposing a district court proceeding between agency decision and appellate decision has achieved nothing but delay," has asked Congress to make its regulations reviewable by the circuit courts under the Hobbs Act, 28 U.S.C. \$2344 (1970). See letter from Thomas J. Heye, CAB General Counsel, to Antonin Scalia, Chairman of Administrative Conference, Oct. 18, 1974; S. 2609, 92d Cong., 1st Sess. The Ferleral Reserve Board has asked the courts to hold its regulations "orders" subject to direct appellate court review under the Bank Holding Company Act, 12 U.S.C. 
may be especially important when Congress deems time to be of the essence, as it did with wartime price regulations and more recently with air and water pollution.

3. Appraisal of Other Objections. The problem of bifurcated review in the area of informal rulemaking cuts both ways for many agencies. On the one hand, there is the often-voiced objection ${ }^{223}$ that it is undesirable to have orders reviewed by the appellate court and regulations by the district court, as is the case under many current decisions. On the other, there is the likelihood that the validity of regulations may in any event be determined by trial courts in enforcement actions that cannot very well be brought in a circuit court because of the frequent need for a fact hearing on the question of violation. One answer would be, as in the Clean Air Act, to forbid the raising of invalidity as a defense; $;^{224}$ this is a harsh measure that may trip the unwary litigant who did not suspect the regulation was meant to apply to him, and we do not recommend it absent the most stringent necessity-as, for example, in the case of price control-for expeditious final determination. ${ }^{225}$ Nor would we recommend certification of validity questions in enforcement proceedings to the appellate court, ${ }^{226}$ for that would split a single case between two forums, with consequent delay and expense. ${ }^{227}$ The only other way to avoid all bifurcation would be to make not only regulations, but all orders, reviewable in the district courts; but that would impose substantial additional burdens on courts and litigants alike. All of these alternatives seem to us much worse than a little bifurcation; after all, the circuit courts can review determinations of validity made in enforcement cases, so any disuniformity or other damage done by bifureated review will be short-lived.

The concurring opinion in Texas v. EPA,,$^{228}$ calling for district court review of regulations, seems to have focused not only upon the role of the trial judge in the taking of evidence but also upon his role as fact sifter. The thesis seems to be that, quite apart from the necessity of a hearing, judicial economy is served and an ultimately correct decision made more likely if a

$\S 1848$ (1970). Sec letter from Thomas J. O'Connell, General Counsel of the Federal Reserve Board, to Antonin Scalia, Chairman of the Administrative Conference, Oct. $10,1974$.

223. Sec, c.g., L. JAFFe, supra note 4, at 423; Mullan, The Federal Court Act: A Misguided Attempt at Administrative Law Reform?, 23 U. Tononto L.J. 14, 16, 29 (1973).

224. 42 U.S.C. \& 1857h-5(b) (Supp. III, 1973).

225. See Yakus v. United States, 321 U.S. 414 (1944) (wartime need for expedition in price control).

226. Such certification is required for substantial constitutional questions arising in enforcement cases under section 211 of the Economic Stabilization Act of 1970 (Temporary Emergency National Court of Appeals), 12 U.S.C.A. \& 1904 (Supp. 1974) as amended, Act of Aug. 24, 1974, Pub. L. No. 93-387, \& 211, 88 Stat. 750. See, e.g., DeRieux v. The Five Smiths, Inc., 499 F.2d 1321 (Temp. Emer. Ct. App. 1974).

227. Cf. Note, Consequences of Abstention by a Federal Court, 73 Harv. L. Rev. 1358 (1960) (the delays attending the practice of abstention by federal courts to ascertain state views on state law).

228. 499 F.2d 289, 321-22 (5th Cir. 1974); see text accompanying notes 160-62 supra. 
trial judge first undertakes the formidable task of organizing and understanding very complex and informal factual records. A mammoth case such as that one, involving the validity of a variety of provisions of Texas's plan for implementing air-quality standards, obviously imposes a considerable burden on any court. While this very complexity makes it all the more imperative that the appellate court ultimately decide, it does not require that three judges do the preliminary digging. But there is no indication that this is what happened in Texas; the complaint is that the burden was great for the writing judge. To the extent that the argument is that prior district court scrutiny facilitates correct appellate decision, we recognize the force of the point. The Supreme Court surely benefits when difficult issues have first been tackled by the circuit courts. The question remains whether in rulemaking cases the gain from the input of a single district judge is great enough to justify the added burden. It should be borne in mind that not all rulemaking cases are as complex on their facts as Texas v. EPA.

This observation brings to mind a related one: Not all regulations are of equal general importance. To provide for direct review of all regulations because some of them are of great import would be overhasty; it might risk burdening the courts of appeals with a myriad of trivial cases that might better end in the district courts. Once again, the uncertainties and burdens of jurisdictional litigation counsel against simply making "important" regulations directly reviewable upon individual determination of importance, as they counsel against the District of Columbia Circuit's apparent position ${ }^{220}$ that the proper forum turns on the necessity for judicial factfinding in the individual case. The best approach would seem to be for Congress to consider separately each category of regulations with a view toward ascertaining whether they are likely to be of sufficient importance to justify bypassing the district courts. In this light, it would seem to make eminent sense that the circuit courts have original review authority over such broad and significant regulations as those setting national air-quality standards or the emission standards for achieving them. ${ }^{230}$ In such cases, it should be added, the probability and desirability of further review in the circuit courts strongly argues that those courts would not be stbstantially relieved if such cases were initially reviewed in the trial courts.

\section{Informal Adjudication}

This amorphous and miscellaneous category, constituting "the vast bulk of administrative adjudication," 231 is defined by a characteristic highly rele-

229. Deutsche Lufthansa A.G. v. CAB, 479 F.2d 912 (D.C. Cir. 1973).

230. As now provided in 42 U.S.C. $\S 1857 \mathrm{~h}-5$ (b) (Supp. III, 1973).

231. Attorney General's Committee on Administrative Procedure, Final Rep. 35 (1951), cited in Gardner, The Procedures By Which Informal Action is Taken, 24 Ad. L. Rev. 155, 156 (1972). 
vant to the choice of a trial or appellate forum for review: the absence of a record based upon a formal adjudicatory hearing. Subject to that constraint, the myriad types of adjudication vary almost infinitely in procedural characteristics-in opportunity for input by interested parties, scope and thoroughness of administrative investigation, nature of the administrative record, if any, and so on. They range from unstructured discretionary decisions of enforcement agencies whether to prosecute to quasi-formal decisions of the Comptroller of the Currency-governed by specific statutory criteria, after extensive investigation, and upon information received informally from all interested parties-whether to grant a bank charter. ${ }^{232}$ This alone would make useful generalization concerning the appropriate forum for review extremely difficult. The difficulty is compounded, however, by our general lack of knowledge about the nature of the heast. In contrast to the formal processes of administrative action, the "procedures which govern informal action by the Government have until the last few years received almost no attention,"233 and most of this complex and diverse terrain remains unexplored. The question of the appropriate forum depends upon more basic variables-such as the nature of the issues typically raised on review, the character of the administrative record, and the procedures available to the reviewing court to supplement that record when necessary-all of which are themselves highly uncertain. The state of our knowledge with respect to the relevant adninistrative practices, and the state of the law with respect to the permissible judicial techniques are alike flitid and developing.

The informal orders of agencies which do little or no formal adjudication are ordinarily reviewed in district courts in suits for declaratory or equitable relief under the general review provisions of the APA. The jurisdictional situation is less clear, however, in the case of agencies whose main business is formal adjudication and some or all of whose "orders" are reviewable in circuit courts under specific statutory review provisions. In FPC v. Metropolitan Edison $C_{0 .}{ }^{234}$ the Supreme Court held that such a provision applies only to formal orders. The statute provided for review of orders arising out of "proceedings under the Act" and required a transcript of the record to be filed with the appellate court. ${ }^{235}$ The Court ruled it inapplicable to an order commencing an investigation to determine "the ownership, operation, management, and control" of the plaintiff company. Not content to hold the order nonreviewable because of its "procedural" and "preliminary" character, the Court further declared that the statutory "orders" were limited "to orders of a definitive character dealing with the merits of a proceeding before the Com-

232. Sec Camp v. Pitts, 411 U.S. 138 (1973), discussed at notes 253-54, 258 and accompanying text infra.

233. Gardner, supra note 231, at 156.

234. 304 U.S. 375 (1938).

235. 16 U.S.C. \& $825 l$ (b) (1970). 
mission and resulting from a hearing upon evidence and supported by findings appropriate to the case."236 In this aspect, however, Metropolitan Edison has not generally been followed. Regulatory orders, for example, suspending ${ }^{237}$ or refusing to suspend ${ }^{238}$ a proposed rate, or accepting a proposed rate for filing, ${ }^{239}$ have been held reviewable by circuit courts even in the absence of a formal record. The appellate courts tend to approach the jurisdictional question in an ad hoc, pragmatic way, as two decisions of the District of Colunbia Circuit illustrate.

In Environmental Defense Fund, Inc. v. Hardin ${ }^{240}$ the court accepted jurisdiction to review the Secretary of Agriculture's refusal to act on a request that he suspend the registration of DDT pending a cancellation proceeding. Review of this important interlocutory order was surely appropriate since later review would be of no use. Since there was no adninistrative record, it was argued that mandamus in the district court was the sole remedy, although the final order in the cancellation proceeding would be taken to the court of appeals. The court disagreed:

There is some authority . . . that only a trial court is capable of reviewing orders issued without the benefit of formal factfinding based on a record. That view has been criticized, however, for dividing between two courts the review of the various orders involved in a single administrative proceeding. Whatever its continuing vitality, that line of authority is especially inappropriate here, where the facts in issue lie peculiarly within the special competence of the Secretary. The district court could do no more than remand to the Secretary, as we do here .....241

Recoguizing that "meaningful judicial review" would be impossible without more of a record, the court remanded the case to the Secretary for a fresh determination or a statement of reasons.

In Medical Committee for Human Rights v. SEC 242 the same court entertained a challenge to the SEC's decision not to prosecute an alleged violation of its proxy rules. There had been no adjudicatory hearing; the action was not, as in Hardin, ancillary to any pending or potential formal proceeding; and the substantive questions could have been raised in a private action in a district court. The court of appeals, however, was held the "more appropriate" forum

236. 304 U.S. at 384.

237. Phillips Petroleum Co. v. FPC, 227 F.2d 470, 475 (10th Cir. 1955), ccrt. denied sub nom. Michigan Wisconsin Pipe Line Co. v. Phillips Petroleum Co., 350 U.S. 1005 (1956).

238. Isbrandtsen Co. v. United States, 211 F.2d 51 (D.C. Cir.), cort. denicd sub nom. Federal Maritime Bd. v. United States, 347 U.S. 990 (1954).

239. Cities Service Gas Co. v. FPC, 255 F.2d 860, 862-63 (10th Cir.), cert. denicd sub nom. Magnolia Petroleum Co. v. Cities Service Gas Co., 358 U.S. 837 (1958). ·

240. 428 F.2d 1093 (D.C. Cir. 1970).

241. $I d$. at $1098-99$.

242. 432 F.2d 659 (D.C. Cir. 1970). 
because the petitioner "does not seek to contest any matters of fact which would require a trial de novo."243

The absence of a formal adjudicatory record justifies, we think, a presumption in favor of district court review. Without such a record, a judicial trial will very often be necessary to determine either the basis upon which the administrator acted or the facts relevant to an evaluation of his action. Furthermore, even where the issues raised are strictly legal, a district court opinion may, in the absence of a formal opinion at the administrative level, be useful to the circuit court in organizing the case for appellate review.

To be sure, we suggested earlier ${ }^{244}$ that, in general, notice-and-comment rulemaking should be reviewed in courts of appeals despite the absence of a trial-type hearing record, and that if further factfinding became necessary the appellate court could refer the case to a district court, a master, or the agency itself. The same treatment might be thought equally appropriate for informal adjudication. There are, however, at least three pertinent differences, of degree if not of kind, between the two types of informal action.

First, review of rulemaking more often presents questions of law or questions of legislative fact that can be resolved on the basis of Brandeis briefs; conversely, adjudication usually hinges on questions of specific fact that may have to be tried. Second, while the APA prescribes no procedures at all for non-record adjudication, it does impose a degree of structure upon the rulemaking process. ${ }^{245}$ The requirements that interested persons have an opportunity at least for written comment and that the agency provide a general statement of reasons virtually assure that an appellate court will have a meaningful record to review. While it is true that in many instances informal adjudication also produces an administrative record, the nature and scope of the records vary widely from one type of action to another and cannot provide the same assurance that appellate review will be feasible. Finally, review of rulemaking much more often involves questions of general importance or broad impact. questions that will eventually be brought to the appellate courts in any event and cannot be postponed without major social costs. Review of informal adjudication, on the other hand, is more likely to affect only the immediate parties and in most cases would not be appealed beyond the district courts.

The distinctions we have drawn do not cut cleanly. Informal adjudication, we repeat, frequently does generate an administrative record suitable for the purpose of review. Moreover, scholars and practitioners of administrative law are coming to recognize a need for greater procedural regularity in the field of informal agency action. ${ }^{246}$ The reforms they contemplate-including a

243. Id. at 672 .

244. See notes 167-222 and accompanying text supra.

245. 5 U.S.C. § 553 (1970).

246. Gardner, supra note 231 . 
requirement that the administrator state the facts and reasons upon which he bases his decision ${ }^{247}$ - would, as a byproduct, yield more adequate records.

Furthermore, deficiencies in the administrative record which make it unsuitable for review can often be remedied without resort to a judicial trial. The $H$ ardin case is sufficient illustration. It is true that the court's decision to remand the case to the Secretary for a statement of reasons, and its assumption that a district court would have had no choice but to do the same, is somewhat inconsistent with the approach taken by the Supreme Court two years later in Citizens to Preserve Overton Park, Inc. v. Volpe. ${ }^{248}$ The Court remanded to the district court to determine, either by testimony or affidavits, the "factors that were considered" by the Secretary of Transportation or his "construction of the evidence"249 in deciding, without a hearing or formal administrative findings, that there was no "feasible and prudent alternative" to building a highway through a park. ${ }^{250}$ Overton Park makes clear, however, that the absence of formal administrative findings or reasons does not necessarily call for a remand to the agency. ${ }^{251}$ Applying the same approach in Hardin, the District of Columbia Circuit might have disclaimed jurisdiction on the ground that the district court was the appropriate forum in which to obtain an explanation for the Secretary's refusal to suspend DDT. Yet it might equally have concluded that if the explanation for the Secretary's action was to be elicited by affidavit or testiniony, rather than by a remand to the agency, district court review would be superfluous, for a court of appeals is no less able than a district court to secure the production of such evidence. This conclusion was impossible in Overton Park, not only because of the absence of a statute giving courts of appeals jurisdiction to review orders of the Secretary of Transportation, but also because the question of whether the Secretary had made an independent judgment or merely rubber stamped a decision of the local city council was a disputed matter possibly requiring oral testimony and crossexamination. Normally, one assumes, an administrator's own explanation of the grounds upon which he acted, "post hoc" rationalization though it may be, would be accepted at face value and could be adequately communicated by affidavit.

Findings and reasons, however, are not the only prerequisite to meaningful judicial review; the court may also need some factual basis on which to evaluate them. This poses no serious problem for circuit court review in cases where an extensive administrative record exists in the form of written materials that can be packaged and filed in the reviewing court as easily as a hearing transcript. The difficulties arise in cases where the record, if there is

247. Id. at 164 .

248. 401 U.S. 402 (1971); see notes $170-73$ and accompanying text supra.

249. Id. at 420.

250. Id. at 405 .

251. Id. at 409 . 
one, is less complete, or less tidy, or where the question of what information was before the administrator when he acted is disputed or uncertain. In such cases, a judicial trial may sometimes be necessary in order to reconstruct the adninistrative record.

In evaluating the frequency with which a judicial trial may be necessary, a key consideration is the extent to which agency action can properly be sustained or challenged on the basis of evidence, judicially adduced, that was not before the agency when it acted. If such evidence is ruled out, and the trial limited to a reconstruction of the administrative record, district court review will obviously be needed much less often. In Overton Park, ${ }^{252}$ and later more explicitly in Camp v. Pitts, ${ }^{253}$ the Supreme Court indicated that in determining whether an order is arbitrary or capricious, "the focal point for judicial review should be the administrative record already in existence, not some new record made initially in the reviewing court." 254 This position is in keeping with the traditional understanding that "the reviewing function is one ordinarily limited to consideration of the decision of the agency or court below and of the evidence on which it was based."255 Yet it is hard to take these statements entirely at face value. In the class of situations with which we deal, the party tendering new evidence may have had no opportunity to be heard at the administrative level. To deny him that opportunity in court might be a violation of due process. ${ }^{256}$ Even if not, it would often reduce judicial review to a rubber stamp, especially where the proffered evidence tended to expose the administrative record as a product of superficial and inadequate investigation. To uphold the administrator's action merely because it is supported by such a record would be to reward him for wearing blinders. In Overton Park, ${ }^{257}$ and again in $\operatorname{Camp}^{258}$ the Court acknowledged that new evidence may be appropriate where the agency's factfinding procedures are inadequate, and this exception may ultimately be held to encompass situations where the agency has acted ex parte and without sufficient effort to inform itself. ${ }^{259}$

Even if one assumes that the administrative record may on occasion be supplemented by new evidence, it does not follow that this must be done

252. Id. at 420. Upon remand in Overton Park, the district court conducted a 25-day trial in which it received voluminous evidence, much of it not contained in the original administrative record, bearing on the Secretary's conclusion that no alternative route was feasible. Citizens to Preserve Overton Park, Inc. v. Volpe, 335 F. Supp. 873 (W.D. Tenn. 1973). The court indicated, however, that its decision would be based exclusively on the administrative record that was before the Secretary at the time he acted. Id. at 882 .

253. 411 U.S. 138 (1973).

254. Id. at 142.

255. United States v. Carlo Bianchi \& Co., 373 U.S. 709, 714-15 (1963).

256. See Londoner v. Denver, 210 U.S. 373 (1908). See also note 215 and accompanying text and note 43 sipra.

257. 401 U.S. at 415 .

258. 411 U.S. at $141-42$.

259. In a variety of situations, federal courts reviewing informal administrative action have admitted new evidence augmenting the administrative record. See, e.g., Brown v. United States, 396 F.2d 989, 991-94 (Ct. Cl. 1968) (Davis, J.). 
through a judicial trial. Alternatively, the reviewing court could, as in Hardin, remand to the agency for a fresh determination in light of the additional information brought to the court's attention. This approach has the advantage of enabling the agency to evaluate the new evidence for itself and would reduce the risk of a judicial substitution of judgment. If frequently employed, however, the remand technique could force the agencies to adopt burdensome factfinding procedures that Congress did not see fit to impose and that could seriously impair the efficiency of the administrative process. We do not attempt to resolve these questions of appropriate procedure. Our purpose is merely to note that on certain procedural assumptions courts of appeals will often be able to perform the reviewing function effectively despite deficiencies in the record.

Our analysis yields no easy generalizations concerning the frequency with which a trial in the district court may be necessary. Until we know much more than we do, it would be premature to recommend wholesale, or even retail, departures from the existing statutory preference for district court review. But just as we do not say that all informal rulemaking should be reviewed in appellate courts, neither do we say that all informal adjudication should be reviewed in district courts. Further study may reveal categories of informal action in which the need for judicial trial, and the added burden upon the courts of appeals, are sufficiently small to warrant a statutory assignment of jurisdiction to the appellate courts.

One class of informal action that immediately comes to mind as a category, or source of categories, for court of appeals review is the occasional informal orders of agencies that mainly adjudicate formally and have statutory review provisions placing their "orders" in the courts of appeals. Informal action by such an agency is often ancillary to a pending or prospective formal proceeding, and district court review, aside from its other inefficiencies, could have the added disadvantage of dividing a single proceeding between two courts. ${ }^{200}$ Not all informal action by formal adjudicatory agencies has this ancillary character-for example, the order complained of in Mcdical Committee may have been altogether remote from the area of formal agency adjudication. Furthermore, even when an informal order does fall within the general subject matter arena in which the agency formally adjudicates, it may be unrelated to any ongoing or inminent formal proceeding. As we have said, ${ }^{261}$ the mere fact that the district court, in reviewing an informal order, may have to decide a legal issue that would ordinarily come to the court of appeals review of a formal order does not seem a particularly troublesome form of bifurcation, since the district court's decision can in any event be

260. See L. JAFFE, supra note 4, at 422 .

261. See notes $223-27$ and accompanying text supra. 
appealed. These considerations suggest as one possible statutory approach, that the standard court of appeals review provisions be construed or revised to cover informal orders ancillary to a pending or imminent formal proceeding. Alternatively, the statutory "orders" reviewable in the appellate courts might, contrary to Metropolitan Edison, be defined to include informal as well as formal orders. The latter option seens preferable, not only because it avoids the jurisclictional ambiguities that lurk in the notion of ancillariness, but also because it makes good sense for informal orders to be reviewed by appellate judges who presumably have acquired a subject matter expertise in the regulatory area in question.

For most agencies, the class of orders that would come directly to the appellate courts under this approach are not numerous and typically involve important enough interests to be appealed in any event. Those instances, probably rare, in which the record is inadequate could be handled by reference to a master, to the agency itself, or, statute permitting, to a clistrict court. There are, to be sure, some exceptions. The informal, highly discretionary orders of district directors of immigration in deportation-related matters falling outside the framework of the formal deportation proceeding typically involve questions of specific fact affecting only the inmediate parties and are rarely appealed. For this and other reasons we have already discussed, ${ }^{262}$ we do not share the view of Professors Davis ${ }^{263}$ and Jaffe ${ }^{264}$ that these orders should be added to the exclusive jurisdiction of the courts of appeals.

Whatever its ultimate.form, a category-by-category approach to the question of appropriate forum seems to us preferable to the ad hoc approach of the District of Columbia Circuit in Hardin and Medical Committee. Under the latter, jurisdiction would apparently depend on a determination in each case as to whether factual questions demanding additional evidence were raised. No doubt such a test would shorten the road to ultimate appellate resolution, but only at the cost of uncertainty and jurisdictional litigation $;^{265}$ no one suggests that a similar approach be adopted in civil actions generally, though to do so would avoid delay in appeal cases where the facts do not have to be tried.

262. Sec notes 109-27 and accompanying text supra.

263. K. Davis, supra note 43, \& 23.03, at 798-99 (1970 Supp.).

264. L. JAFFE, supra note 4, at 422 .

265. The uncertainty problem arises only on the assumption that district court and appellate court jurisdiction are mutually exclusive, so that a district court would be forced to disclaim jurisdiction in cases not requiring a trial and therefore amenable to immediate appellate review. Uncertainty and judicial conflict would disappear, on the other hand, if the district courts, too, adopted the pragmatic policy of accepting jurisdiction in all instances where rerouting the parties appears to serve no practical purpose in the particular case. The result-a de facto system of concurrent jurisdiction-would be contrary to the congressional intent, however, that circuit court jurisdiction be exclusive with respect to "orders" within its domain and might also provide fertile opportunities for forum-shopping. 


\section{Spectalized Courts and Exclustve Venue}

In France and other continental countries, administrative actions are reviewed by separate tribunals or courts. ${ }^{206}$ In the British Commonwealth, the idea of separate administrative courts or divisions is spreading. ${ }^{267}$ In this country Congress has on isolated occasions created narrow specialized courts to review specific kinds of administrative action and has localized review of other administrative actions in a single court of appeals.

The Court of Customs and Patent Appeals; as it is now known, was created in 1909 to hear challenges to tariff determinations ;208 in 1929 it was given nonexclusive jurisdiction to review Patent Office determinations on patent applications and between competing applicants in interference proceedings. ${ }^{209}$ The Commerce Court, abolished three years after its creation in 1910, was given exclusive jurisdiction to review ICC railroad orders. ${ }^{270}$ Congress vested exclusive jurisdiction to determine the validity of price regulations during the Second World War in the Emergency Court of Appeals, ${ }^{271}$ and made a somewhat comparable provision for substantial constitutional questions under the 1970 price control legislation. ${ }^{272}$ The Court of Clains has jurisdiction, exclusive in cases involving over $\$ 10,000$, of contract and certain other claims against the United States. ${ }^{273}$ The Tax Court has nonexclusive jurisdiction to determine challenges to tax assessments. ${ }^{274}$ The Court of Military Appeals has review power, exclusive except for limited collateral attack over

266. The French Conseil d'Etat and the inferior Tribunaux Administratifs have exclusive jurisdiction over "acts of the administration"; other matters are litigated in the ordinary civil courts. Similar systems are found, for example, in Belgium, Italy, and West Germany. See generally L.N. Brown \& J. Garner, French Administrative Law (2d ed. 1973).

267. New Zealand created an Administrative Division within its Supreme (trial) court in the Judicature Amendment Act, N.A. Stats. 1968, No. 18. Sec also (N.Z.) Public and Administrative Law Reform Comis., 5Th and 6Th Reports (I972, 1973). A committee appointed by the Australian Attorney General has recommended the creation of a single administrative tribunal to review administrative decisions closely and a federal administrative court to exercise over it a more limited supervisory power. Commonwealth Administrative Review Committee, Report, Austr. Parl. Paper No. 144 (1971). Rejected by the Franks Committee in Great Britain in 1957, CommitTeE oN Tribunals AND ENQUIRIES, REPORT, CMD. No. 218, at 25-29 (1957), the idea of an administrative court or division is under restudy there. See id. 4059 (1969). In Canada, administrative review responsibilities, previously scattered among provincial courts, were recently consolidated in a single two-tier Federal Court with relatively few other signifieant duties. Federal Court Act 1970, 19 Eliz. 2 c. 1 (Can.).

268. Act of Aug. 5, 1909, ch. 36, § 29, 36 Stat. 105. Initial reviewing power is now vested in the Customs Court, with a further right of appeal to the Court of Customs and Patent Appeals. Sec 28 U.S.C. \$§ 1582, 1541 (1970).

269. Act of March 2, 1929, ch. 488, 45 Stat. 1475. Sce 28 U.S.C. \& 1542 (1970).

270 . Act of June 18,1910, 36 Stat. 539, repealed by Act of Oct. 22, 1913, 38 Stat. 208, 219.

271. Act of Jan. 30,1942 , ch. $26, \S 204,56$ Stat. 31 .

272. Economic Stabilization Act of 1970, as ancnded, $\$ \S 211$ (b), (c), 12 U.S.C.A. $\$ 1904$ note (Supp. III, 1973), as anended, Act of Aug. 24, 1974, Pub. L. No. 93-387, $\S \S 211$ (b), (c), 88 Stat. 750 (noted in 12 U.S.C.A. (Supp. 1974)).

273. 28 U.S.C. \$ 1491 (1970); sce also id. \$ 1346 (a) (2).

274. 26 U.S.C. \& $6213(a)(1970)$; see also statutes cited in note 273 supra. 
court-martial convictions. ${ }^{275}$ Exclusive jurisdiction over FCC license denials and over EPA regulations setting air-quality standards or new source performance standards (among other examples) is in the Court of Appeals for the District of Columbia Circuit. 276

\section{A. Advantages}

Examination of the history of specialized courts suggests three principal advantages over the prevailing American practice of review in the ordinary courts. It can produce judges more familiar with administrative issues in general and with individual administrative programs in particular, thus improving the quality of decision. By minimizing actual and potential intercourt conflicts, it can. reduce or eliminate disuniformity and uncertainty in the law administered by the several agencies and the attendant forum shopping. And it can relieve the burden on the ordinary courts, thus improving the conditions for decisionmaking in both administrative and nonadministrative cases. These advantages would not be without corresponding costs, as we shall see below. First, however, we shall examine the three hypothesized advantages.

1. Relief for the Regular Courts. Relieving the caseload of the regular courts was apparently one explicit reason for the creation of the Court of Customs Appeals in 1909. The Second Circuit was "swamped" with a multitude of challenges to tariff determinations, causing delay in the resolution of tariff cases and "a serious obstruction to the disposition of . . traditional litigation." 277 Later the same court was given patent jurisdiction in order to relieve the burden on the D.C. Circuit. ${ }^{278}$

It is now generally accepted that the regular federal courts, and especially the courts of appeals, are critically overloaded. ${ }^{279}$ To solve this problem by adding judges or circuits would, it is said, merely create new problems. Already the danger of intracircuit conflicts, the unwieldiness of enlarged en banc proceedings, and the lack of collegiality characteristic of existing courts of 13 or 15 judges have led to recommendations for doubling the number of circuits. Yet there are dangers in the multiplication of circuits too. ${ }^{280}$

The seriousness of the overload problem is largely beyond the scope of the present paper, but we add a caveat. It is fashionable to assume that recent upward trends in docket entries will continue, but predictions ought to be based upon more sophisticated subject-by-subject analysis. ${ }^{281}$ As an example,

275. 10 U.S.C. $\$ 867$ (1970). For the confusing scope of habeas corpus see D. CurRIE, supra note 6 , at $164-211$.

276. 47 U.S.C. \& 402 (b) (1970); 42 U.S.C. \& 1857h-5(b) (Supp. III, 1973).

277. F. Frankfurter \& J. Landis, The Business of the Supreme Court 149-51 (1928)

278. Nathanson, The Administrative Court Proposal, in 2 Administratrve Conference of the UntTed States, Recommendatrons and Reports 198, 211 (1970-72).

279. See, e.g., H. FrIENDLY, supra note 10.

280. See note 86 supra. (1974).

281. See Casper \& Posner, The Supreme Court's Caseload, 3 J. Legal Studirs 339 
one must take care in basing projections upon the fact that direct appeals to the Ninth Circuit from EPA determinations rose suddenly to the staggering sum of 219 in the first half of fiscal 1974. ${ }^{282}$ The EPA has been going through a crash period of adopting regulations and approving implementation plans under a brand-new statutory scheme with tight rulemaking deadlines; and review of its actions must be sought within 30 days. Such challenges can be expected to trail off almost as suddenly as they appeared.

In any event, to the extent that present or projected caseloads impair or threaten to impair the quality of adjudication, any significant relief must be regarded as a substantial gain. Creation of a separate court or courts to handle administrative cases would directly further this objective, essentially by permitting the appointment of more judges without bloating the circuit courts or multiplying the circuits. A 10 percent reduction in cases, for example, would be tantamount to appointing 10 new circuit judges. ${ }^{283}$

Care must be taken, however, to avoid overburdening a new court of administrative appeals. If all administrative cases were transferred to such a court, its docket would immediately approach that of our busiest circuit-the beleaguered Fifth (3,294 cases in fiscal 1974) - in which 15 judges have had to cut corners in order to keep abreast. One way to avoid this would be to give a new court jurisdiction over only as many categories of cases as it could handle with a manageable complement of, say, nine judges. Such a scheme would require monitoring of workloads and continuing jurisdictional adjustments, creating both an administrative burden and the danger of sudden changes in the law as a class of cases is shunted into or out of the new court's jurisdiction. It might therefore be preferable, from this point of view, to create more than one new court, though changing workloads could present similar problems.

A principal difficulty with the overload argument is that it provides no justification for singling out administrative cases for transfer to specialized courts. ${ }^{284}$ The same objective could be achieved by separate courts for criminal or diversity cases or for those arising under the Federal Employers Liability Act (FELA). If such alternatives prove politically infeasible or undesirable in

282. 1974 Semi-AnNuat A.O. Report, supra note 1 , at 13.

283. See text accompanying notes 38,58 supra. This estimate assumes that administrative cases are of average difficulty. The THIRD CIRcuit Time STudy, supra note 37, rather surprisingly shows administrative cases to average a smaller investment of judge time than other cases, but Judge Leventhal has testified to a subjective conclusion that the opposite is true in spades in the D.C. Circuit. See Statement of Judgc Leventhal, supra note 2 , at 9 . Obviously, administrative cases are highly variable in difficulty.

284. A reason for singling out a class of administrative cases for separate treatment might exist if that class in itself imposed an extraordinary burden on the courts, as apparently was true of customs cases before 1909, see notes 277-78 and accompanying text supra. There are fears that a recent surge in social security cases before the SSA may correspondingly glut the district courts in the near future. See notes 64-94 and accompanying text supra. But it is no more accurate to attribute the general problems of the circuit courts to administrative cases than to federal question cases not involving the federal government, which clearly outnumber them. See 1974 A.O. REPORT, supra note 1, table B7. 
substance, then, of course, an administrative court or courts should be considered to the extent that relief is needed for the circuit courts. ${ }^{285}$

2. Certainty in the Law. Whenever concurrent jurisdiction over a class of controversies is vested in more than one tribunal, the danger arises that conflicting decisions, unless resolved by higher authority, will produce substantive inequality, uncertainty, and, if liberal venue provisions are available, unseemly forum shopping. These considerations have figured prominently in the creation of specialized tribunals here and abroad. The establishment of the Court of Customs and Patent Appeals was preceded by "costly conflicts in decisions" under the tariff laws. ${ }^{286}$ The Commerce Court was set up in response to a Presidential message that stressed, among other things, the "great uncertainty" resulting from "contrariety of decision" in various courts reviewing ICC decisions. ${ }^{287}$ The Clean Air Act gives the District of Columbia Circuit exclusive jurisdiction to review certain EPA regulations because they "are national in scope and require even consistent national application." 288 The same considerations, among others, have long prompted suggestions for specialized courts of exclusive jurisdiction over tax and patent matters. ${ }^{289}$ And in the environmental field, EPA attorneys we interviewed acknowledged that a specialized court would relieve them of their present uncertainty, engendered by conflicting circuit court decisions, as to basic procedures they must follow in passing upon state implementation plans.

From the standpoint of uniformity and certainty, it makes no difference whether one or more new courts are created, so long as subject matter lines do not overlap. But on some types of issues, overlap is almost inevitable. For example, different courts reviewing different agencies might reach divergent results as to common procedural or constitutional questions, or even as to such substantive matters as ratemaking, licensing, or antitrust policy. In any case, it is important for uniformity that the circuit courts be deprived of jurisdiction to decide the relevant questions regardless of the posture in which they arise, whether directly in agency review or by appeal from a district court. If a new court, for example, is to hear pre-enforcement challenges to regulations, it must also hear-either originally, by certification, or on appeal

285. We have not discussed the possibility that a special court or courts might relieve the burden of administrative cases on the district courts. Because the district courts do not to any significant degree function as collegial bodies, there is less objection to relieving their caseloads by the appointment of additional judges. See H. Fr1endLY, supra note 10 , at $28-31$. But there presumably must be some limit, if only so that administrative tasks can be managed with some efficiency; and when that limit is approached the same considerations may be weighed as in connection with the circuit courts.

286. Sce F. Frankfurter \& J. Landis, supra note 277, 148-52.

287. Message of President Taft, quoted in H.R. Rep. No. 923, 61st Cong., 2d Sess. (1910), reprinted in 2 B. Schwartz, The Economic Regulation of Business and INDUSTRY 1031-32 (1973). note 223 .

288. S. ReP. No. 91-1196, 91st Cong., 2d Sess. 41 (1970). See also Mullan, supra

289. See H. FRIENDLY, supra note 10 , at 153-71. 
from the district court-any challenges to validity that are permitted to be raised in defense of a civil or criminal enforcement proceeding. Certification from a regular trial court was provided for in connection with recent wage and price controls, ${ }^{290}$ but it had the unfortunate effect of requiring litigation of the same case in two forums at the same time and does not seem highly desirable. Original enforcement jurisdiction would make it advisable to create a new trial court as well as an appellate one for more efficient ascertainment of the facts and, at least in criminal cases, would require the new court to sit in the vicinity of the offense. New judges would have to be appointed or to sit in every state. Since the transfer of jurisdiction over matters now heard in the district courts would further expand the jurisdiction of the new court, with consequent impact upon the caseload, appeal from the district courts to the new court would therefore seem far preferable.

Again, however, the question arises whether it is appropriate to single out administrative cases if the elimination of intercircuit conflicts is the goal. A solution to the problem of disuniformity or uncertainty ought to focus upon those categories of cases in which that problem is or is expected to be especially serious. The likelihood of conflict depends, among other things, on the novelty and the complexity of the issues and the presence of issues on which social attitudes may influence decisions. The significance of conflict depends largely on the importance of the cases and the need for prompt, not merely eventual, resolution. There are old and relatively settled administrative statutes as well as new and unsettled ones, simple and trivial statutes as well as complex and crucial ones. Some affect strongly held social policies or require rapid resolution and some do not. The same is true of nonadministrative cases. There is one difference: Dispersed review of the decisions of a single agency injects disuniformity into a system that, unlike criminal or accident cases, is presumably uniform at the trial level. Nevertheless, if greater certainty is our goal, it might be better to attack the problem wherever it is most acute rather than obliquely by singling out administrative cases.

Moreover, before drastic alterations are made in the present jurisdictional system in the name of removing disuniformity, a serious effort should be made to determine the extent of the problem. In Canada, for example, a commentator observing that one reason for creation of a new federal court was the "obvious" danger of conflicting provincial decisions noted that it was "difficult to point to this having occurred in practice."201

290. Economic Stabilization Act of 1970, 12 U.S.C.A. § 1904 (Supp. 1974), as amended, Act of Aug. 24, 1974, Pub. L. No. 93-387, §211, 88 Stat. 750 (noted in 12 U.S.C.A. (Supp. 1974)).

291. Mullan, supra note 223, at 23-24. See the doubts raised by Judge Friendly as to the lack of proof that, outside of the tax field, there are serious problems of unresolved conflicts or that the Supreme Court is overburdening itself to resolve conflicts. Friendly, Averting the Flood by Lessening the Flow, 59 CoRNELL L. REv. 634, 654-55 (1974); Testimony of Judge Henry Friendly Before Commission on Revision of the Federal Court Appellate System, 1974. 
3. Better Understanding. Perhaps the dominant rationale for creation of specialized administrative courts has been the notion that review of highly technical administrative decisions requires a better grasp of the subject matter than can be expected from the generalist judge. Frankfurter and Landis rationalized the Court of Customs Appeals on the ground that customs decisions confronted judges with problems "outside their usual province of experience."292 President Taft, in urging establishment of the Commerce Court, maintained that the issues on review of ICC decisions were "often technical," requiring "knowledge of the business." ${ }^{293}$ Patent cases, Judge Friendly argues, present issues "beyond the ability of the usual judge to understand without the expenditure of an inordinate amount of educational effort . . . and, in many cases, even with it." ${ }^{294}$ British admirers of the French administrative courts headed by the Conseil d'Etat applaud the decision to entrust jurisdiction to experts who understand what they are reviewing rather than to ordinary judges who are often "strangers to the administrative process and unsympathetic to its needs" and whom the authors scornfully characterize as "the reasonable man on the Clapham omnibus." 295

It is obvious that concentrated experience in handling a particular category of cases facilitates understanding. A court whose sole function is to review FPC decisions would quickly become familiar with pipeline rate regulation even if its judges had no previous background in the subject. Further, if it were thought desirable, such judges could be chosen on the basis of their prior training and experience. The decider will invest more time and effort in learning the administrative field if he can expect the knowledge gained to prove useful later on. He can decide more speedily because he need not obtain a general education in the field case-by-case. The litigants, too, will find it more efficient to present cases before judges who need not be given a cram course in the background technology. And it goes without saying that the judge who knows what he is doing is less likely to make accidental errors through misunderstanding of the technology or of the body of the law being applied. The sensible client, one supposes, would prefer to hire a tax lawyer in a tax case, and a patent lawyer in a patent case; the same philosophy should

292. F. Frankfurter \& J. LANDIs, supra note 277 , at 148-52.

- 293. See B. Schwartz, supra note 287, 1031-32.

294. H. FRIENDLY, stepra note 10 , at 156-57.

295. L.N. Brown \& J. GARNeR, supra note 266 , at 10, 156-61. See also the recommendation of the Law Commission (U.K.) that proposals for an administrative court or division be taken off the shelf because of the view "held by some" that "a lack of expertise" sometimes renders ordinary judges "unable to get near enough to the administrative decision" to review it to best advantage, C $\mathrm{MrND}$. No. 4059, at 7 (1969); the statement of the sponsor of New Zealand's legislation providing for an administrative division that the judges of that division "will have a thorough knowledge of administrative law and of the background and the economic and social policies which the particular Acts concerned were designed to implement," D. Benjafield \& H. WhITMORE, PRINCIPLes of Australian Administrative Law 362 (4th ed. 1971); and the argument of the Australian Attorney General's committee for a federal administrative court because a "developing expertise" would be "very desirable" Report of Commonwearth AdMrnistrative Review Committee, Austr. Pard. Paper No. 144, at 72-73 (1971). 
perhaps apply to judges. As Judge Friendly asks, why should "lack of understanding" be "deemed a precious asset"? 296

The logical extension of this reasoning is to create separate courts for each narrow subject, administrative or otherwise-the narrower the better. To state this proposition, however, is to raise a red flag. Our system has largely been premised on the notion that such extreme specialization not only carries certain dangers, ${ }^{207}$ but is unnecessary because increased specialization brings diminishing returns. Not every kind of case is so complicated that only one who does nothing else can understand it well enough to perform the rather limited function of judicial review. In any event, any effort to create more or less specialized tribunals for administrative or for any other cases ought to be based upon a detailed analysis of the kinds of cases in which there is a significant need. The challenge to automotive emission standards in International Harvester Co. v. Ruckelshaus, ${ }^{298}$ for example, presented a much more compelling argument for an expert tribunal than does the ordinary social security or workmen's compensation case. And once again, as illustrated by patent and antitrust litigation, the problem is not peculiar to administrative cases.

In sum, the three principal alleged advantages of a separate administrative court point in somewhat different directions. The unburdening of the circuit courts is neutral as to which cases should be transferred and what sort of courts set up, so long as the regular courts are relieved of a significant burden and the new courts not overloaded. The elimination of disharmony argues for transfer of cases in the most disharmonious categories, and preferably to a single court. The creation of better understanding may call for relatively narrowly defined jurisdiction over cases involving a high degree of technical or other difficulty.

\section{B. Disadvantages}

1. Loss of the Generalist Perspective. The more time one devotes to a particular subject, the less time one has to learn about others. Analogy has been one of the geniuses of the common law; it surely has its place in administrative review. To put blinders on judges and confine them to narrow compartments not only creates the risk of significant disuniformities but also enhances the danger that issues may be resolved on the basis of ignorance as to past experience in related fields. It seems likely, for example, that we have a better law of administrative procedure because the same courts review a number of different agencies, and a better procedure in both courts and agencies because of the comparisons perceived by courts that review them both. Excessive

296. H. FRIENDLY, supra note 10 , at 157 .

297. See notes 299-324 and accompanying text infra.

298. 478 F.2d 615 (D.C. Cir. 1973). 
compartmentalization can also frustrate substantive programs in which there is a need for coordination. ${ }^{299}$

Another aspect of the generalist perspective is the possible advantage of the outsider's unprejudiced vision. The cognoscenti have indispensable information on technical matters, but they may also share preconceptions that the fresh mind unclouded with intimate knowledge would wish to reexamine. A specialized court made up of experts in the art of marine navigation would surely have been less likely than was the generalist Learned Hand to find the whole industry remiss in failing to adopt the radio. ${ }^{300}$ Similarly, the skeptical outsider may have something of value to add in administrative cases just because he has not been steeped in the traditional wisdom with all its imperfections.

2. The Loss of Diverse Views and the Concentration of Power. That different courts decide the same issue in different ways is commonly lamented; unifornity is a value much prized. As Judges Friendly and Oakes have pointed out, however, correct decision may often be promoted by filtering an issue through a variety of judges with a variety of points of view. ${ }^{301}$

What the first court decides wrongly may be better understood by the second or third. When the Supreme Court waits for additional lower court decisions before tackling a difficult new problem, it is often in anticipation that a few more heads may contribute to ultimate understanding of the issues. Collegial decision by the first court is a safeguard against error, but it is hardly failsafe. Indeed, the dynamic of the decisionmaking process itselfcleference to one's colleagues, the persuasive powers of a single member, the assignment of primary responsibility to the writing judge and the limitations of the parties presenting a particular case-dilutes somewhat the element of collegiality and increases the possibility that a fresh look by another body may afford additional insights. Moreover, as will be considered more closely below, ${ }^{302}$ an entire court or its majority may come to embrace a particular point of view that may not be representative. Thus, while conflicting decisions resulting from multiple venue can be damaging if not promptly resolved, they have important uses in the short run. Perhaps it would be wiser to make certain that conflicts can be resolved rather than to try to prevent them-if that can be done without undue burden to the system.

Dispersion of jurisdiction among several courts not only assures that

299. In Illinois, for example, one argument for consolidating pollution-control agencies was that it would be unfortunate to clear up an air-pollution problem only to create water pollution. See Ogilvie, Special Message on the Environment 2 (April 23, 1970).

300. The T.J. Hooper, 60 F.2d 737 (2d Cir. 1932).

301. H. FRIENDLY, supra note 10, at 186; Oakes, Developments in Environmental Law, in 3 ENviron. L. REP. 50001, 50011 (1973) (opposing establishment of a specialized environmental court: "[t] here is a lealthy cross-fertilization which occurs from having different courts rule on given environmental questions and then living witli those decisions for a time").

302. See notes 306-12 and accompanying text infra. 
a number of judges may contribute their judgment to the solution of difficult problems; it also vastly reduces the potential of a single wrong decision to harm an administrative program or those subject to it. The more important the administrative program, the greater the dangers of giving sole power over it to a single court. Commenting on the death of the Commerce Court, Frankfurter and Landis observed that the courts are increasingly "arbiters of the economic and social life . . . at times of the whole country," and that "the issues reach . . . beyond the experience and insight of a single court, however well equipped." 303 "Less than ever," they concluded, "is it likely that Congress will entrust these issues to five men, even though invested with the authority of bench and woolsack and subject to the corrective scrutiny of the Supreme Court."304

3. The Quality of the Judges. The doubt that seems to merit the most careful attention in connection with the creation of any tribunal of limited subject matter concerns the quality of the judges. If one could be confident that the judges of a new administrative court would be as able and disinterested as the average judge of the circuit courts, one could view the prospect with more equaninity. But it is not at all clear they would be.

One question is whether the nature of the job will be such as to attract persons of the same caliber as those who now sit on the federal bench. To some, perhaps, it is the very variety of the present circuit judgeship that makes it both prestigious and intellectually satisfying. To spend one's life deciding social security cases, for an extreme example, might seem less exciting than being a federal circuit judge and to make one less of a figure in the legal community. ${ }^{305}$ If, on the other hand, all the interesting administrative business were taken from the circuit courts and given to a prestigious new tribunal, it would be the former whose seats might become less desirable, as their caseload would consist in larger proportion than today of such grist as automobile accidents and frivolous prisoner petitions. At worst both regular and special courts could be damaged, if a substantial body of interesting business were taken from the former and distributed in narrow categories among a number of the latter. Knowledgeable second-raters might replace more intelligent generalists, and it is to be doubted that such a development would make for sounder decisions.

A second aspect of the problem of judge quality, prominently voiced during the debates on the creation and abolition of the ill-fated Commerce Court, is that judges may be not so much incompetent as biased. ${ }^{300}$ This problem in turn has two aspects. First, there is the danger that pressures

303. F. Frankfurter \& J. Landis, supra note 277 , at $173-74$.

304. Id. at 174 .

305. Cf. Friendly, supra note 291, at 649 (the increasing criminal diet may make district judgeships less attractive).

306. See F. FRAN KFURTER \& J. LANDIS, supra note 277 , at 153-74. 
may be brought to bear upon the appointment process. "We merely remind the Senate," said opponents of the Commerce Court, "of the tremendous influences that will inevitably surround the selection of such a tribunal." ${ }^{307}$ Professor Joseph Sax has explained persuasively why these pressures are greater the narrower the jurisdiction of the tribunal:

[Ordinary] judges ... will spend only a tiny fraction of their time and energy dealing with environmental disputes. For this reason the process of judicial selection is not significantly affected by anyone's estimate of a given judge's attitudes about those issues. This is a most important fact, one which can hardly be applied to any institution that deals regularly with environmental matters. A President or a Governor who is choosing an environmental council cannot avoid consideration of the attitude that important interest groups--whether the oil industry or conservation organizations-will adopt toward that choice. ${ }^{308}$

The second danger is that bias may develop after service on a separate court. One possibility is that, as they come to know more and more about the subject-or from the outset if chosen because of prior knowledge-the judges may increasingly substitute their judgment for that of the agency in which Congress has vested discretion. In contrast, the uninitiated general judge may be inhibited by knowledge of his own inadequate information from interfering too much with agency discretion. ${ }^{309}$ How much interference is too much depends, of course, on the point of view. An agency is likely to favor considerable deference to its experts, and those it regulates may find or believe that the inexpert judge lets the agency get away with murder. On the other hand, private attorneys we interviewed also favored review in the ordinary courts, but for the opposite reason: They feared that specialist judges might be too deferential to agencies with which they regularly deal and whose attorneys they have come to know personally. ${ }^{310}$ The architects of the Comnerce Court, cognizant of these dangers, provided for assignment of regular circuit judges on a revolving basis to prevent "the possibility of the court becoming packed with life nembers, dealing with a special subject, where their

307. Id. at 157. (1970).

308. J. Sax, Defending the Environaent: A Strategy for Citizen Action 109

309. The comments of a number of federal agencies reflect a belief that an environmental court could become a "super-agency" where the judges would not hesitate to substitute their views for those of the administrator ....

President, Acting Through the Attorney General, Report on the Feasibility of Establshing an Enviromanental Court System VI-24 (1973) [hereinafter cited as REPort of THE PREsident]. See also Hines \& Nathanson, Preliminary Analysis of Enurironmental Court Proposal Suggested in the Federal Water Pollution Control Act Amendments of 1972 , in id. at C-13.

310. See, e.g., argument of Senator Hardy against the Commerce Court, in F. FRANKFURTER \& J. LANDIS, supra note 277, at 161: "when you get your court set aside for the trial of one class of cases only, with representatives of the United States, far removed from the people, upon one side, and the representatives of the great railroads ... on the other, after a while your impartial judge begins to see things in a little different light from what he did before." 
opinions, or a majority of them, are fixed one way possibly leaning toward the interests of the railroads." 311 This concession, naturally, laid the legislation open to the criticism that it did not even provide expert judges. ${ }^{312}$

Evaluating the danger that judges of a specialized court may be incompetent or biased is largely an exercise in conjecture. The lessons of experience are helpful but not conclusive. Not only is the success of specialized tribunals a mixed bag; observers also differ in their assessment of success. No hint of personnel problems is found in recent British appraisals of the French Conseil d'Etat. ${ }^{313}$ Judge Friendly reports a "lack of any serious criticism" of the Court of Clains or of the Court of Custons and Patent Appeals, ${ }^{314}$ and close observers have applauded the work of the wartime Emergency Court of Appeals. ${ }^{315}$ The Tax Court is thought by many practitioners to be pro-Government. ${ }^{316}$ The Commerce Court was abolished largely because it was believed to be pro-railroad, but later commentators, pointing out that the railroads had fared even better with the circuit courts than with the Commerce Court, have questioned that judgment. ${ }^{317}$ Of the federal administrative agencies themselves, one encounters criticism on grounds both of craftsmanship and of partisanship that one does not often hear about the circuit courts. ${ }^{318}$ As Professor Nathanson remarked in evaluating a recent proposal for a separate court of adninistrative review, "[t] he charge that regulatory commissions over the years tend to be dominated by the industries they regulate, whether justified or not, is too common to be ignored entirely in establishing new institutions." 319

An additional consideration suggested by the history of the Commerce Court is that a specialized court, whether or not actually partisan, is peculiarly susceptible to being thought partisan. ${ }^{320}$ If a single court frustrates a popular adninistrative program, it is natural for those disappointed to blame judicial bias; the finger cannot so easily be pointed where responsibility is shared by eleven circuit courts. ${ }^{321}$ Confidence in the integrity and intelligence of decision makers may make unfavorable decisions more acceptable.

The spectrum of experience permits distinctions; varying models of specialized tribunals pose personnel problems in different degrees. The status

311. 2 B. Schwartz, supra note 287, at 1060.

312. See id. at 1096.

313. See L.N. BRown \& J. GaRnER, supra note 266.

314. See H. FrIENDLY, supra note 10 , at 154 .

315. See Hyman \& Nathanson, Judicial Revieze of Price Control: The Battlc of the Meat Regulations, 42 ILL. L. REv. 584, 630 (1947); Nathanson, supra note 278, at 198, 212-13.

316. See H. FRIENDLY, supra note 10, at 166.

317. See F. FRANKFURTER \& J. LANDIS, supra note 277, at 164.

318. For milder examples, see the materials collected in W. GeLLHORN \& C. BYSE, AdMinistrative LaW: CAsEs and Comments 1-53 (6th ed. 1974); G. Rodinson \& E. GeLlmoRN, The AdMINISTRATtve Process 831-33 (1974).

319. Nathanson, supra note 278 , at $198,214$.

320. See note 317 and accompanying text supra.

321. See F. FRANKFURTER \& J. LANDIS, supra note 277, at 164. 
of the tribunal is surely relevant to the willingness of top people to serve. Greater prestige and job security make it more attractive to be an article III judge than to be a board member, and tenure during good behavior is strong armor against improper influence. ${ }^{322}$ To equal or approach the personnel level of the courts of appeals, any new courts should enjoy article III status.

But tenure alone may not be enough. The more narrowly jurisdiction is defined, the greater the danger of making the job repetitive and unattractive or of low prestige, the greater the pressure of special interests upon the appointive process, and the greater the danger of excessive or insufficient deference through overfaniliarity with personalities or programs. The Commerce Court was an especially unpropitious institution in this regard. It dealt with a single agency then regulating a single potent industry-in contrast to the more successful Court of Customs and Patent Appeals and Emergency Court of Appeals, both of which were concerned with the economy as a whole, ${ }^{323}$ to the Conseil d'Etat with its general administrative jurisdiction, and to the District of Columbia Circuit, which combines exclusive jurisdiction over certain administrative functions with a healthy diet of general federal jurisdiction.

The one redeening feature of the Commerce Court was that the job was important enough to be attractive. But this very importance was another substantial factor in the court's downfall. The intense political controversy surrounding the issues on review assured maximum pressure on the appointive process and enhanced the likelihood that the court would be considered partisan. ${ }^{324}$ Courts of narrow specialized jurisdiction may have a better chance of surviving if they deal with relatively obscure, noncontroversial matters such as government contracts, customs and patents. On the other hand, if the job is quiet enough not to invite political intrusion, it may lack sufficient sex appeal to attract the best judges. Are we certain that the lack of outcry over the Court of Claims and the Court of Customs and Patent Appeals is attributable to good performance rather than to public indifference? Timing, of course, is important: The Emergency Court of Appeals and the Commerce Court had the good fortune to go largely out of business before the issues became stale and the glamor faded. Tales of administrative agencies proceeding from zeal to indolence over time furnish a useful admonition.

4. Jurisdictional Litigation. The jurisdictional lines separating administrative from general courts should be drawn as precisely as possible in order to minimize litigation over the proper forum. There is one type of such litigation that would be reduced by providing a single forum for each subject category: the present litigation over proper venue among courts of concurrent jurisdiction. But the determinants of proper venue under existing law have

322. See The Federalist, Nos. 78, 79 (A. Hamilton).

323. See Nathanson, supra note 278 , at 214 .

324. See F. FrankfurTer \& J. LANDIS, sipra note 277, at 162-64; H. FrIENDLy, supra note 10, at 153-54; Nathanson, supra note 278, at 209-10, 214. 
been rather carefully picked out by years of decisions; ${ }^{325}$ a new crop of uncertainties might be created by a carelessly drawn statute creating new distinctions based upon subject matter rather than geography. To give a court jurisdiction over "environmental" cases, for example, would invite wasteful jurisdictional litigation, ${ }^{326}$ much as has the French provision giving the Conseil d'Etat jurisdiction over matters "affecting the administration." 327 It would appear best to emulate existing statutes that define review jurisdiction simply in terms of the agency whose order is being reviewed, taking pains to clarify such ambiguities as whether or not "orders" includes regulations, ${ }^{328}$ whether preliminary steps in the administrative process are to be reviewable, and what is to be done if issues within the experience of the new court arise in enforcement or other proceedings somewhere else. ${ }^{329}$

5. Litigation Convenience. In cases of small money value, centralized jurisdiction in a single court may deprive litigants of significant economies afforded by a district court or even by a circuit court forum. ${ }^{330}$ This possibility suggests either defining the jurisdiction of an administrative court so as to exclude categories rich in small cases or providing for the court to sit on circuit, as some current and past specialized courts have done. ${ }^{331}$ This latter expedient would be constitutionally necessary if the new court's jurisdiction extended to the trial of criminal cases. ${ }^{332}$ The travel burden might make the job less attractive.

325. See generally D. Currie, supra note 6, at 657-62. Congress does not help when it provides for review in the "appropriate" circuit court, since there is no general venuc statute for those courts. E.g., section 307 (b), Clean Air Act, 42 U.S.C. $\$ 1857$ h-5 (b) (1) (1970).

326. See Report of the President, supra note 309, at VII-1 (1973).

327. On the one hand, some acts of the government, such as operation of a ferry. have been held within the jurisdiction of the regular civil courts because they were the sort of activity that could be conducted on the same terms by private enterprise. On the other, acts of private parties have been held to be within the jurisdiction of the administrative courts when they concerned what was considered to be a public service. Moreover, the civil courts may determine "flagrant irregularity" in governmental action; damage actions for government infringement of personal liberty; compensation for takings; certain tax cases; and accidents involving government employees. Finally, in a criminal (but not in a civil) case a regular court may pass upon a defense questioning the validity of an administrative action. Brown and Garner, on whose work this footnote is based, point to one case in which after eleven years of jurisdictional litigation the parties started all over in the proper forum; but they conclude that the seriousness of jurisdictional conflicts should not be exaggerated because "the rules which define the respective competences are now [after a hundred years] reasonably well settled." L.N. BROWN \& J. GaRnER, supra note 266 at 80 . This would obviously not be true of a new administrative court.

328. See notes 140-60 and accompanying text supra.

329. The possible complexities of such a provision are suggested by the details of Judge Friendly's proposal for a patent court, to which among other things cases would be removed from state or federal courts whenever the validity of a patent was called into question by way of defense. H. FRIENDLY, supra note 10, at 160 .

330. For a detailed discussion of litigation convenience as between district court and circuit court, see notes 28-36 and accompanying text supra.

331. The Tax Court, the Court of Claims and the Emergency Court of Appeals. Sce H. FR1ENDLY, supra note 10, at 169; Nathanson, supra note 278, at 212.

332. U.S. Const. art. III, § 2. See Hines \& Nathanson, silpra note 309, at C-16. 


\section{Models}

If the problems of circuit court overload, disuniformity and lack of expertise are found to be serious, and if the overload problem cannot be cured by surgery on such other portions of the case body as diversity and post-conviction cases, consideration will surely be given to alteration of the scheme for reviewing administrative decisions. A number of model review schemes could be concocted and tested against the considerations laid out in the preceding sections of this Article, including elimination of all direct circuit court review and the creation of a large number of highly specialized courts. We limit ourselves to a few of the more prominent models.

1. Exclusive Jurisdiction in Designated Courts of Appeals. If our sole object were to minimize disuniformity and improve the quality of adjudication, rather than to relieve the circuit courts of part of their mounting caseload, we might well opt against the creation of a new court but in favor of giving the existing circuit courts exclusive jurisdiction to review action of designated agencies, as the District of Columbia Circuit now has for certain types of FCC and EPA actions. SEC cases, for example, might be parceled out to the Second Circuit ; FPC cases to the Fifth; CAB cases to the Third, and so on. The judges would presumably acquire an expertise in the subject matter and yet still bring to bear the perspective of the generalist. Conflicts would be minimized or eliminated. The total appellate caseload would not be increased and, to the extent that the same issue need not be relitigated circuit after circuit, might be slightly reduced. Political pressures upon both the appointment and decision processes would presumably be minimized. ${ }^{333}$

The fact is, however, we are very much interested in docket relief and therefore turn our attention to the desirability of increasing judicial capacity rather than merely redistributing the load.

2. Exclusive Jurisdiction in Administrative Appeals Conrts. A court of administrative appeals could take a variety of forms. Its jurisdiction could be limited to a single agency or homogeneous class of agencies, or could embrace a wider and more heterogeneous range. Its members could be appointed from sitting appellate judges or from non-judges. The latter could be selected either for their preexisting expertise in one or more of the subject areas of adjudication or on the basis of more general qualifications similar to those ordinarily used in picking appellate judges. If sitting judges were to be designated, their appointment to the new court could be permanent or for a fixed term, after which they would return to their home bench. The new court could be divided into permanent panels based on subject matter or shifting panels like the present courts of appeals. All panels could sit in Washington, or some

333. For reservations as to the completeness of this protection, see notes $334-35$ and accompanying text infro. 
could sit elsewhere, achieving a measure of regionalization. Conflicts among the panels would presumably he resolved en banc; and panels specialized by subject matter could refer issues of general administrative law to the full court. Many other variations could be imagined.

(a) Subject Matter Jurisdiction. The most important variable is subject matter jurisdiction. In general, we think it highly desirable that the jurisdiction of any court of administrative appeals be quite broadly drawn in order to reduce the pressures of special interests on appointment and decision, to avoid the loss of perspective that can come from overcompartmentalization, and to assure that the job is varied enough to be interesting. We concede that special circumstances or urgent need may in exceptional instances justify singlesubject courts. Our best judges tell us that only technical experts can understand patent cases well enough to do them justice, ${ }^{334}$ and a persuasive case has been made for a Court of Tax Appeals. ${ }^{335}$ But the acceptability of a special court in such fields as patents and taxation may depend heavily on the lack of high political controversy or of a narrowly defined interest group constituency. Even if the need were comparable, we should be less sanguine as to the success of a court limited, for example, to labor or to environmental cases.

The suggestion of an environmental court was raised by the 1974 amendments to the Water Pollution Control Act and opposed by the Attorney General in a bulky 1974 report. ${ }^{336}$ Several of the report's objections can easily be met. Threshold litigation over what constitutes an "environmental" case would present less of a problem if jurisdiction were limited to cases arising under named statutes or under statutes administered by the EPA. Giving the new court appellate jurisdiction only would eliminate the need for circuit riding in criminal cases and reduce generally the inconvenience of a centralized forum. The objection that there are too few cases to keep such a court busy appears to have been cured by time, ${ }^{337}$ though prediction of future workloads is hazardous. ${ }^{338}$ But the hard problems of the specialized court, stressed by the Attorney General, remain: the possible loss of broad perspectives for resolving general issues, the lost benefit of diverse views, the danger of overreview by expert judges, the concentration of power-all exacerbated by the danger of partisan appointments in a politically sensitive field. "It would be difficult, if not impossible," wrote Professors Hines and Nathanson, "to create a special court to handle environmental matters which would not be regarded as partisan by

334. See, e.g., H. FRIENDLY, supra note 10, at 153-61, and authorities cited therein.

335. See, e.g., id. at 161-71, and authorities cited therein.

336. REPORT OF THE PRESIDENT, silpra note 309.

337. A computer printout furnished by the Administrative Office to the Commission on Revision of the Federal Court Appellate System shows that direct appeals to the circuit courts from the EPA in fiscal 1974 numbered 454; that does not exhaust the environmental cases.

338. See notes $281-82$ and accompanying text supra. 
a substantial segment of the parties affected by its decisions." ${ }^{339}$ In the absence of the strongest showing of need, we should be very reluctant to place so much power over such important matters in the hands of a single court not insulated from appointive pressures by substantial non-environmental business.

Further, the Attorney General expressed serious reservations as to the need for an environmental court, reporting that the affected agencies had expressed confidence in the ability of the ordinary courts to handle even the toughest environmental cases. The position of the EPA here is especially instructive:

We believe that the courts have shown that their ability to cope with the environmental issues involved is adequate, and is certainly not inferior to their ability to cope with the technical issues involved in nonenvironmental cases.

The parties will both do their best to explain the issues to the court in layman's language. In our experience there are few issues that cannot be explained adequately in this way. . . .

The kinds of environmental issues that typically arise do not directly involve obscure matters of scientific theory or techniques. Instead, they are questions of evidence, of the form "What do the facts show the effect of a given factor (concentration of a pollutant, use of a control method, use of a pesticide) to be on a variable (human health, pollution emissions, the survival of certain species of wildlife) ?" Such questions are relatively easy compared with those that often arise in patent cases concerning whether a given invention differs from a previous one to the extent necessary to make it patentable ....340

While the Deputy Assistant Attorney General for the Land and Natural Resources Division has more recently indicated a desire to reevaluate the report's conclusion in the light of further experience indicating considerable technical difficulty, ${ }^{341}$ we believe several decisions of the circuit courts under the Clean Air Act, technical as the issues are, eloquently substantiate the Attorney General's position that the sacrifice of expertise is not so serious as to justify the risks of a narrow specialized environmental court. ${ }^{342}$

The 1971 Ash Council report, agreeing that separate courts to review each federal agency would be undesirable, ${ }^{343}$ proposed the establishment of a single

339. Hines \& Nathanson, supra note 309 , at C-20.

340. REPORT OF THE PRESIDENT, supra note 309 , at B-55, B-56.

341. See Address by Walter Kiechel, Jr. before ABA Comm. on Environmental Law, April 27, 1974.

342. Sce, c.g., International Harvester Co. v. Ruckelshaus, 478 F.2d 615 (D.C. Cir. 1973); Portland Cement Ass'n v. Ruckelshaus, 486 F.2d 375 (D.C. Cir. 1973), cert. denicd, sub nom. Portland Cement Corp. v. Administrator, 417 U.S. 921 (1974); Texas v. EPA, 499 F.2d 289 (5th Cir. 1974). This assessment is made against the background of the experience of one of the authors as Chairman of a full-time state pollution control board for two and a half years. See also Hines \& Nathanson, supra note 309, at C-13, C-14 (describing several district court opinions under NEPA as "monuments," along with "equally impressive" decisions in other technical fields as antitrust and railroad receiverships, to the capacity of the federal judicial system "to master a body of learning and experience far removed from the classical pathways of the law").

343. To so limit the court's scope would seriously diminish its attractiveness to 
Administrative Court to review agency decisions in the fields of transportation, power, and securities now made by the ICC, CAB, Federal Maritime Commission (FMC), FPC and SEC. It argued that a specialized court with a limited jurisdiction would yield better understanding of the issues and relief of the burdened circuit courts. ${ }^{344}$

The Administrative Conference, echoing a report by Professor Nathanson, was critical. There were too few such cases to give the courts of appeals signifcant relief: only 176 in fiscal 1969, less than 3 percent of their caseload. Moreover, the jurisdiction proposed was so narrow as to render the new court unable to make the anticipated "contributions to uniformity in administrative law" and as to create the risk that the court might "become or give the appearance of becoming identified with the agency or industry point of view." $345 \mathrm{We}$ agree. The optimum administrative court should enjoy the safeguards of a broader jurisdiction, and we are not convinced that the Ash Council proposal singles out those administrative decisions most deserving of review by a specialized court.

(b) A Suggested Model. Jurisdiction of an administrative court should be determined with an eye upon the problems to be corrected. It should include the most technically difficult, the most novel and uncertain, and the most time-consuming cases in order to maximize the reduction of poor understanding, disuniformity and overburden. Absent detailed study of each category of cases, we can only make tentative suggestions. Attacks upon regulations under such new and technical statutes as those governing air and water pollution, noise, occupational health and consumer safety seem obvious candidates on all three scores. Individual cases as well as regulations from the Nuclear Regulatory Commission (NRC), the Federal Aeronautics Administration (FAA), the Food and Drug Adninistration (FDA), the FPC, the FMC, the FCC, the SEC and the ICC are likely to be both important and complicated, even though the governing statutes have been much interpreted. NLRB cases loom large in number but not, we think, in technical complex${ }^{i t y},{ }^{346}$ and, though forum shopping has sometimes proved of concern, there is

the most qualified candidates for judgeships, would encourage an overassociation with the agency being reviewed, and might lead to a usurpation of the agency's policy responsibilities. It would also preclude development of integrated administrative procedures as well as uniform application of procedural advances.

President's Council on Executive Organization, New Regulatory Framework: REPORT ON SELECTED INDEPENDENT Regulatory AgeNCIES 54 (1971).

344. Id. at 51-56.

345. See Full Statement of Views of the Administrative Conference on the Report of Selected Independent Regulatory Agcucies of the President's Adrisory Conncil on Exccutive Organization, in 2 AdMINISTRATIVE Conference of THE UNITED STATES, RecomMENDATIONS AND REPORTS 27, 30-31 (1971); Nathanson, supra note 278, at 198.

346. The General Counsel of the NLRB reports that "cases from this agency do not involve complex scientific or technical questions"; and that of 298 circuit court cases in fiscal 1974, 66 were decided without oral argument and 72 without opinion. Letter from Peter G. Nash, General Counsel to the NLRB, to Antonin Scalia, Chairman of the Administrative Conference, Oct. 25, 1974, at 2, 5. Judge Leventhal testified before 
substantial intercircuit uniformity today. ${ }^{347}$ Trade Commission cases range in theory from enormous antitrust matters of considerable technical complexity to relatively simple matters of deceptive advertising. The former should be reviewed by the same courts reviewing other antitrust cases to avoid disuniformity; the latter seem to present no cause for a special court. Immigration, social security, longshoremen's act, employee dismissal ${ }^{348}$ and mining cases, we suspect, tend to be uncomplicated, the issues not novel, and the case for a local forum strong. Additional categories of cases can be analyzed in the same manner.

Thus, as a preliminary sketch, one can visualize a separate article. III appellate court, or perhaps two such courts, with jurisdiction to hear appeals from individual decisions of the NRC, FCC, FPC, ICC, CAB, FMC and SEC, and challenges to regulations adopted by these agencies, and by the FDA, the FAA and the EPA, and under the consumer-product safety and OSHA provisions. For the sake of consistent application of the law, the administrative court should also have appellate jurisdiction over district court cases-for example, enforcement actions-arising under the same statutes. To create such a court would eliminate intercircuit conflicts and uncertainties in these important fields; it would facilitate judicial understanding of these complex problems; and it would remove a large and growing body of cases from the overburdened circuit courts. ${ }^{349}$ Jurisdiction would be broad enough that no

the Commission on Revision of the Federal Court Appellate System on May 21, 1974 that even contested NLRB cases are often "routine" and of "no significant weight" since they frequently turn on "whether there is substantial evidence of a refusal to bargain, or discriminatory discharge."

347. See note 98 and accompanying text supra.

348. Our impression is generally supported by the view of the General Counsel of the Civil Service Commission that, "except for the areas of pay and classification, which sometimes prove troublesome to the courts, most of the Commission's cases do not involve highly technical or complicated questions." Letter of Anthony L. Mondello to Antonin Scalia, Chairman of the Administrative Conference, Oct. 21, 1974, at 2.

349. Determining the caseload such jurisdiction would impose is somewhat difficult not only hecause of shifting litigation patterns but also because of the way the statistics are reported. Direct appeals from the listed agencies to the circuit courts numbered 823 in fiscal 1974 according to the 1974 A.O. REPORT, supra note 1, table B3, and to the supplemental computer printout cited in note 337 supra:

Direct Appeals from Selected Agencies to

$\begin{array}{lr} & \\ \text { AEC (now NRC) } & 2 \\ \text { CAB } & 37 \\ \text { CPSC } & 0 \\ \text { EPA } & 454 \\ \text { FAA } & 2 \\ \text { FCC } & 90 \\ \text { FDA } & 15 \\ \text { FMC } & 7 \\ \text { FPC } & 166 \\ \text { OSHA } & 35 \\ \text { SEC } & 15\end{array}$

Professor Nathanson, supra note 278, at 199 n.7, reports there were 96 ICC cases taken to three-judge district courts in fiscal 1969 ; the A.O. REPORTS, supra note 1, do not list these separately. There were also appeals from district court cases involving the above agencies. Most of the others are buried under the heading "other." The total caseload 
single industry would be likely to dominate, even over time, the selection of judges. Finally, the breadth and importance of the jurisdictional spectrum we have outlined is sufficient, we believe, to make the job highly attractive. Stripping the regular courts of these important cases does diminish their glamor but leaves them such challenging matters as constitutional attacks upon state action and the enforcement of civil rights laws. Such a court would meet many of the objections made by the Attorney General against an environmental court and by the Administrative Conference against the Ash Council proposal. ${ }^{350}$

The possible objection that a jurisdiction embracing such a grab bag of diverse specialties would be incompatible with the stated goal of decisionmaking by experts brings us to the further question of how members of the new court should be selected. If oversight were confined to a single agency or homogeneous group of agencies, it might be feasible to draw members from non-judges with preexisting expertise in the subject area. Indeed, the sole convincing rationale for so narrow a jurisdictional grant would be to maximize the court's subject-matter expertise. This aim arguably would be best promoted by appointing persons with special knowledge of the technology and economics of the regulated industry, since the technical competence required to come to grips with the scientific issues presented in environmental or nuclear-licensing cases is altogether different from that required, say, for intelligent evaluation of the economic regulation in such a field as transportation.

Given even a narrowly defined jurisdiction, however, we would recommend against this method of appointment, since it would maximize the danger both of political pressure in the appointment process and of overintrusive supervision by the judiciary. Moreover, such appointments would minimize the likelihood of obtaining either the perspective of the generalist or two additional varieties of expertise that would be of value on a court of administrative review. One is the art of judicial review of administrative action; it calls for an understanding of the administrative process, a feeling for the proper limits of the judicial role, a sophistication in the application of such standards as "substantial evidence," "arbitrary or capricious," and so on. It is the kind

on the basis of the above figures might approximate 1000 , about equal to that of the Seventh and Eighth Circuits. Nine judges can survive such caseloads only because they include easy cases that can be subjected to summary procedures that would seldom be available to a special court whose cases are selected precisely because they are the most difficult. Significant increases, moreover, may be expected in the near future in such categories as water pollution, noise, OSHA, and consumer product safety, where programs are just getting under way; and a probable dropoff in litigation over air pollution regulations should be partly offset by a significant gain in corresponding enforcement actions. To add NLRB cases would increase the load by 641 cases on the basis of 1974 figures so it would approach in bare numbers that of the Second Circuit, or about half that of the Fifth.

350. Compare Professor Nathanson's opposition to the Ash Report with his concession that to "concentrate judicial review of all the federal regulatory agencies in a separate division of the federal courts of appeals" would be "fairly debatable." Nathanson, supra note 278 , at $215-16$. 
of skill one would expect to be acquired by the judges of the District of Columbia Circuit by virtue of their heavy dose of administrative appeals. The final kind of expertise might be labeled "procedural"; appellate judges who regularly hear a gamut of civil and criminal cases, especially the latter, become experts in the requirements of due process. ${ }^{351}$ The narrow specialization which is calculated to maximize the subject-matter expertise is by no means the best prescription for the other two talents.

As the jurisdiction of the court is broadened to include diverse agencies and subject matter, the desirability and even the feasibility of staffing it with preexisting subject-matter expertise become increasingly doubtful. If the special court were intended to be an "expert" body in the sense that its members come to the bench already qualified as experts by their pre-judicial experience, no member could be considered an expert in more than a small part of the subject areas that comprised the court's business. For example, if one member of the court were chosen for his experience in the field of natural gas regulation, another for his background in environmental matters, still another for his knowledge of securities law, there would be a great danger either that the specialists in a particular sector of the court's jurisdiction would come to dominate the panel in cases arising in that area or that the court would eventually decompose into sub-specializing panels in order to bring maximum subject matter expertise to bear upon each case. Furthermore, since fewer judges would be chosen from each field of expertise, constituent groups might have an even stronger incentive to press for the appointment of a sympathetic member than if the jurisdiction of the court were narrower.

If, on the other hand, members of a special court with broad jurisdiction were chosen from non-experts and expected to acquire their knowledge simply through frequent and continuing on-the-bench exposure to the several areas of litigation, the argument would be a different one: Because of the diversity of cases coming before them, the judges could not be truly expert in any. But to insist upon judges who are truly technical experts may be to lose sight of the limited function of judicial review. More likely, all that is needed is the sort of familiarity that the District of Columbia Circuit has acquired in a number of administrative fields by virtue of its concentrated though varied administrative diet. As Judge Leventhal has argued, "judges are generally 'quick studies' "; reviewing courts "do not need enough knowledge or understanding to determine what the government should do" but require only enough background understanding for what is "primarily a general appraisal

351. This sensitivity might be thought merely another name for what we have been calling "the perspective of the generalist," but the two are not identical. The latter refers to the breadth of background and sympathy a judge brings to his task by virtue of his experience of life; the former is the more specific competence he acquires through practice in adjudicating claims of procedural unfairness. 
of fairness, and in that they are expert."352 Thus, we do not think the lack of narrow expertise is a serious objection to a court with broad administrative review jurisdiction.

For similar reasons, we believe it would be highly desirable-especially if the jurisdiction of the court were to embrace a broad range of agencies-for its members to be appointed from sitting circuit court judges. A sitting judge transferred to the court of administrative appeals would hopefully bring to his new assignment a breadth of perspective not ordinarily to be found in the narrow specialist, along with some degree of experience in evaluating administrative action and in enforcing procedural fairness. And constituency pressure for the appointment of benign judges, though not eliminated altogether, would be abated somewhat by virtue of the limited range of candidates eligible for appointment, and the frequent absence of any well-defined differences in attitude among the candidates.

If the members of the special court were selected from sitting appellate judges, the question would arise whether appointment was to be permanent or temporary and, if the latter, whether for a fixed term or at the appointee's pleasure, the judge returning in either case to the circuit court from which he came. Three considerations favor temporary appointment. First, there is the possibility that too few judges of the highest caliber would be attracted to a lifetime position on a court they might view as less prestigious and less interesting than the circuit courts. Second, there is the contrary possibility that curtailing their jurisdiction would make the circuit courts less attractive and create a strong demand among the judges for a tour of duty on the special court. Third, it may be desirable to supply the new court, through regular turnover, with a continuous infusion of new blood and fresh attitudes, to avoid staleness, rigidity and loss of interest. Stronger considerations, however, argue for permanence of appointment. First, and most important, it would defeat a cardinal purpose of the special court if its nembers were relieved of their duty just as they began to acquire a true mastery of the job. Second, a revolving-door court would be less likely to achieve high prestige and drawing power than one with membership as stable as that of other appellate courts. Finally, a double-edged consideration: An increase in the frequency of appointment would multiply the opportunities for political influence but at the same time would tend to make the special court more broadly representative of the appellate bench as a whole, thus neutralizing any bias present in the initial selection process. On balance, we believe the weightier argument favors permanence, but we do not regard the choice as critical.

\section{Conclusion}

Creation of even the most acceptable court of administrative appeals would be a radical departure from our established system of judicial review. 
We should be hesitant to incur the risks that always attend new institutions in the absence of a strong showing that the present system has serious flaws that cannot be cured by less drastic measures. ${ }^{353}$ The judges themselves say the courts of appeals are heavily overloaded, and we have no basis for disagreement. It might be wiser, however, to deal with this problen by liniting jurisdiction over diversity cases, which are peripheral to the function of federal courts; by providing for increased finality in criminal cases, because of the infinitesinal returns produced by the enormous investment of judicial time in sifting prisoner petitions, ${ }^{354}$ or even by the creation of additional circuits. $^{355}$ In any event, the overload problem is no reason for singling out administrative cases. The same relief would be afforded by the creation of specialized courts for diversity or criminal cases. As for intercircuit conflicts, forum shopping and uncertainty, we think it must first be shown that these problens are serious enough to warrant major surgery, and that they are especially acute in the administrative area, before a jurisdictional change designed specifically to meet them would be appropriate. We think it food for thought that, in all the agencies we contacted, only one intercircuit conflict was put forward as having seriously impeded agency operations. ${ }^{350}$ Finally, while an administrative court would no doubt be marginally more competent in deciding difficult administrative cases than the regular circuit courts, the latter have performed impressively in environmental cases, which are among the most difficult; and the affected agencies generally have expressed satisfaction with the ability of the appellate courts to understand and cope with

353. Perhaps the path of wisdom lies in the view that by and large our system of review by general constitutional courts has worked reasonably well, and that it is only in specific areas where one can anticipate a problem or shortfall in performance, that changes should be charted.

Id. at 14.

354. See H. FrIEndLy, supra note 10, at 139-52; Friendly, Is Innzocence Irrelevant? Collateral Attack on State Criminal Judgments, 38 U. CH1. L. Rev. 142 (1970).

355. See note 86 supra.

356. For the one serious EPA conflict, see text following note 289 supra. The AEC, now the NRC, reports no intercircuit conflicts, and no adverse effects from potential conflicts, during the past five years; the FAA, Consumer Product Safety Commission, SEC, Comptroller General and Federal Reserve report they have had no problems. The $\mathrm{CAB}$ reports a single conflict in five years on which certiorari was not sought because the Solicitor General thought the issue "sui generis" and the sums at stake insufficient. The NLRB has suffered nine conflicts since July, 1972. In three the Board chose not to seek certiorari, awaiting "better vehicles" to present the issues; in five of the remaining six the Supreme Court resolved the conflict.

As for the related forum-shopping issue, none of the agencies responding to our inquiry reported a significant problem. The NLRB, as to whose decisions such forum shopping has been suspected in the past, reports that the problem of duplicate review is solved by transfer under 28 U.S.C. $\$ 2112$ (1970) (giving the agency power to file the record and thus to determine which of several possible appeals courts will hear a pending appeal), and that forum shopping has no "real impact" upon operations. See letters to Antonin Scalia, Chairman of Administrative Conference, from General Counsel Offices of the AEC, Oct. 7, 1974; Dep't of Transportation, Oct. 31, 1974; Consumer Products Safety Commission (CPSC), Nov. 18, 1974; SEC, Oct. 30, 1974; Dep't of Treasury, Oct. 8, 1974 ; Federal Reserve Board, Oct. 10, 1974; CAB, Oct. 18, 1974; and NLRB, Oct. 25, 1974. See also Hines \& Nathanson, supra note 309, at C-16, C-17 (the performance of the federal courts in environmental cases generally "reveals little grounds for complaint about inconsistency"). 
technical issues. ${ }^{357}$ In sum, we are doubtful that there is any compelling reason to single out administrative cases for review in a separate court. The problems of overload and uncertainty, if found to require action, might be better approached directly.

This conclusion is buttressed by the stubborn drawbacks of even a general administrative court-the inherent loss of diversity of view, jurisdictional uncertainties that may survive the best efforts at drafting, and the need for continual readjustment of jurisdiction to accommodate shifts in caseload or in novelty. Not least, there is the danger long ago perceived by Franlfurter and Landis, of concentrating great power in a small number of individuals. If this proved unacceptable in the narrow field of railroad regulation, it is even more questionable where the very heart of our national regulatory prograns is at stake. There is security in the dispersion of power, and that ought not be lightly discarded.

357. In addition to the communications included in the Report of the President, supra note 309 , sce the responses of the AEC, Comptroller General, Consumer Product Safety Commission, FAA, Federal Reserve Board, ICC, NHTSA (highway safety) and SEC to our questionnaire. Letters to Antonin Scalia, Chairman of the Administrative Conference, from Office of General Counsel of AEC, Oct. 7, 1974; CPSC, Nov. 18, 1974; Dep't of Treasury, Oct. 21, 1974; Dep't of Transportation, Oct. 30, 1974; Federal Rescrve Board, Oct. 10, 1974; ICC, Nov. 5, 1974; and SEC, Oct. 10, 1974. Of the agencies we questioned, only the General Services Administration (GSA) and the military liave expressed any dissatisfaction on this score. The former's concern was witl governunent procurement cases: "Many judges .... experience difficulty in distinguishing between the general concepts and the specialized ones." Letter to Antonin Scalia, Chairman of Administrative Conference, from GSA, Dec. 24, 1974. The Army argues that "most district judges are not qualified to decide" the "complex technical and scientific questions" in patent and certain contract cases. The Navy, principally concerned with constitutional problems such as reservists' wigs and counsel at summary courts-martial, says that "while the courts have displayed sufficient understanding to deal with purcly scientific questions ...., they have been singularly inept in understanding the coin. plexity of the day-to-day problems of the military society ... [and] repeatedly interfere in military matters wherein they have little or no competence." Letter to Antonin Scalia, Chairman of Administrative Conference, from Dep't of Defense, Dec. 6, 1974. While the necessity of living with review in the regular courts for at least the short term might dampen any public expressions of discontent, we think the agencies' responses not without significance.

Tlie creation of an administrative court, however, would facilitate the provision of technical staff help, if that be thought desirable, to the judges. To equip every circuit court, not to mention every district court, with experts in the entire gamut of relevant knowledge would be prohibitive and highly inefficient. A pool of such talent to be assigned to various courts as needed would preclude the establishment of a confidential staff relationship between judge and expert such as might develop on a single administrative court. Lawyers for the parties are likely to oppose such technical assistance in fear that the unseen expert, whose views cannot be challenged because they are kept confidential, will actually make the decision. An alternative might be a technically qualified master who would write a report open to party criticism, or a court-employed expert who would give his views in open court. Either of these would deprive the judges of the significant values of confidential advice.

The Illinois Pollution Control Board was equipped with technically qualified assistants-sanitary engineers-who worked under the close supervision of the Chairman. They worked not on whole cases but on selected technical issues referred to them by the Chairman and served very largely as translators of technical language. They also raised questions for the Board to put to the parties. Board control of matters of policy was of course aided by the fact that the Board heard only pollution cases. But on balance we believe that a small staff of technical advisors could function effectively in connection with a broadly defined court of administrative appeals and could be kept by strongminded judges from unduly influencing decisions. In any event, we think the outlook for such advisors distinctly better on such a court than in the circuit courts. 
Finally, there remains the possibility, or legitimate apprehension, of improper influence on the appointive process. We have argued that the broad jurisdiction envisioned for such a court would reduce the vulnerability of the court to political influence on the appointment process, but we must sound a note of caution. A broad and diverse jurisdiction is no guarantee that regulated firms and industries or other interested groups will not press for the appointment of friendly judges. It is not the narrowness of the court's jurisdiction, but its exclusivity, that supplies the motive for such pressure. A court that heard all $C A B$ business, even if it heard much else besides, would be well worth the airlines' capturing. One inight reasonably hope that, with many influences being brought to bear, none would be effective; and that no single interest group could persuasively demand a "seat" on the court when so many others had as good a claim. But one should not bank too heavily on this hope. Cutting across the various fields of regulation, there is, after all, a fairly constant opposition between what might be called the "consumer" interest and the "industrial" or "utility" interest. A potential appointee whose background conmended him to the natural gas or electric power industry is apt to be acceptable to railroad, airline and shipping interests as well and, by the same token, unacceptable to consumer and environmentalist groups in general. No doubt this greatly oversimplifies the matter. There are many areas of conflict between industries (between competing transportation modes or energy sources, between carriers and shippers, between wholesale and retail gas suppliers, and so on) and of potential conflict between consumers and environmentalists. When these qualifications have had their full due, however, breadth of jurisdiction would still be at best an unreliable safeguard against interest-group pressure. ${ }^{358}$ In short, we do not favor the establishment of an administrative court.

\section{Proposals for a National Court of Appeals}

An impressive array of prominent judges, attorneys and scholars have recently endorsed proposals for a National Division of the Court of Appeals intended to resolve intercircuit conflicts, settle important questions of federal law, and relieve the dockets of the Supreme Court and of the circuit courts. ${ }^{359}$

358. There is a related danger. Tradition has come to dictate the geographical distribution of judgeships within existing circuits and has been said to have affected both geographical and ethnic composition of the Supreme Court from time to time. Division of jurisdiction on subject matter lines could encourage a corresponding tradition of allocating seats on an administrative court along lines either of special interest or of subject matter competence. We should view any such development as highly alarning: Courts are not the place for voting according to interest-group representation, both because too few interests can be represented and because the theory of judicial (as opposed to legislative) review is that more neutral values shall prevail.

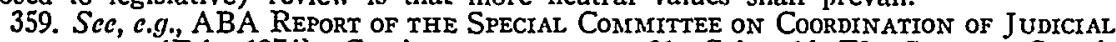
IMPRoveMENTS (Feb., 1974) ; Carrington, supra note 31; Griswold, The Supreme Court's Cassload: Civil Rights and Other Problems, 1973 U. ILL. L.F. 615; Rosenberg, Planned Flcxibility to Mect Changing Needs of the Federal Appellate System, 59 CORNELL L. Rev. 576 (1974); Statements of Judge Hufstedler and of Mr. Griswold Before the Commission on Revision of the Federal Court Appellate System, April 1, 1974. 
Details are both variable and hazy. Some, like Dean Griswold, favor lifetime appointments to the new division for stability and continuity of decision; others, like Professor Carrington, prefer brief assignments of regular circuit judges, perhaps by the Chief Justice, to avoid specialization or to relieve pressures on the appointing process. Some, like Judge Hufstedler, would have the new court review decisions of the regional circuit courts : otbers, including Dean Griswold, would give it jurisdiction now vested in the regional courts in order to avoid a fourth judicial tier. The plans of the ABA and of the Advisory Council of Appellate Justice would make decisions of the new court final only after they had lain before the Supreme Court for a specified time without adverse action.

The most difficult problem, which is not adequately resolved by any of the proposals, would be establishing the criteria for determining which cases should go to the National Division. The ABA committee recommended that the Supreme Court should determine this question within gtuidelines specified by Congress, suggesting possible National Division jurisdiction over collateral attacks on criminal convictions, tax cases, review of federal administrative decisions and cases fron state courts of last resort. Judge Hufstedler, agreeing that Congress should list categories for the Supreme Court to choose from, includes tax and patent cases, direct and collateral review of state criminal convictions, review of the NLRB, SEC, FCC, FPC, FAA and ICC, nonconstitutional intercircuit conflicts, and such federal statutory matters as Congress may designate. Dean Griswold is less specific, arguing that the new court should have jurisdiction not of all cases within a subject category, lest it become overly specialized, but of cases "where a prompt decision, having nationwide validity, is desirable." 360 This, he says, would exclude nearly all criminal and diversity cases and "other types of cases turning largely on their facts, or without any general or national significance."381

The variety of these proposals makes it difficult to evaluate their impact upon the system of judicial review of administrative action. In general, we endorse Judge Friendly's criticism of the National Division proposals. ${ }^{302} \mathrm{He}$ sees no proof that the Supreme Court is too busy, leaves important conflicts too long unresolved, or wastes time resolving unimportant ones. He doubts that the circuit courts would be significantly relieved by creating an additional court to review their decisions. He fears that the new scheme would impose additional burdens on the Court because its inaction would result in the establishment of national law. He points out that there are too many administrative appeals to be lodged in a single court and that centralization

360. Griswold, supra note 359 , at 632 .

361. Id. at 629 .

362. See Friendly, supra note 291 ; Statement of Judge Fricndly Before the Commission on Revision of the Federal Court Appellate System, 1974. 
would impose a substantial financial burden on the small litigant in many administrative cases.

If the National Court were to replace rather than to review the circuit courts, its impact would be similar to that of a general court of administrative appeals to the extent that its workload consisted of administrative cases. Commingling some nonadministrative cases would help retain a generalist perspective but would impair the ability of the new court to develop a consistent administrative law. The problem of centralized power over important areas of the law would remain, as would a serious risk of jurisdictional litigation unless lines were drawn very carefully indeed. To give the new court jurisdiction over "all cases needing prompt national decision," for example, would create hideous jurisdictional disputes.

If, on the other hand, the National Court were to review decisions of the courts of appeals, conflicts could be resolved without losing the value of diverse views where that is significant. But the relief such a scheme would afford the ordinary courts would be much reduced, for all cases reaching the new court would already have been litigated through the circuit courts. Professor Carrington anticipates that once an issue has been settled by the new court, suits raising the same question would no longer be filed, as they now are, in other circuits. $^{363}$ Quantifying the saving is obviously difficult. And the additional price of this scheme is to subject the parties to the costs and delays of still another level of appellate review. We view this as the less desirable alternative. ${ }^{364}$

363. Carrington, supra note 31, at 616.

364. As this Article went to the printer, the Commission on Revision of the Federal Court Appellate System unveiled a proposal for the creation of a permanent National Court of Appeals to decide cases referred by the Supreme Court or transferred by a court of appeals. Sce Remarks of Senator Roman L. Hruska at the National Conference on Appellate Justice, Jan. 26, 1975, reprinted in 121 Cong. Rec. S 1077-80 (daily ed. Jan. 28. 1975). The Supreme Court could refer any case within its appellate jurisdiction and would be expected to promulgate rules to govern its discretion in so doing. The courts of appeals could transfer any case in which there was an actual intercircuit conflict or in which "a persuasive showing" was made that "an immediate authoritative determination" of a dispositive, recurring question of federal law was "in the national interest." The National Court could refuse to accept cases transferred from the regional courts, and its decisions on the merits would be reviewable on certiorari.

We have not yet had an opportunity to give this important new proposal the careful consideration it deserves. We do, however, perceive some difficulties. The proposal deals directly with one of the problems discussed in this section: the lack, as Senator Hruska put it, of "confldence that the Supreme Court in the decades ahead can be expected adequately to satisfy the needs for stability and harmony in the national law as the demands continue to increase." Id. at S 1078. It appears largely to avoid the problem of a fourth tier, as in nearly all cases the new court would supplant either Supreme Court or court of appeals. But we do not share the Commission's view that "there would be no occasion for litigation over jurisdiction." Presumably this conclusion is based upon the fact that the decision to send a case to the National Court would be discretionary and (we would fervently hope) not itself subject to review. But cf. 28 U.S.C. \$ 1404(a) (1970), authorizing interdistrict iransfers for litigation convenience; some such decisions have been reviewed by mandamus under 28 U.S.C. \& 1651 (1970), see, c.g., Hoffman v. Blaski, 363 U.S. 335 (1960). We do not think the discretionary nature of the decision precludes litigating about it. While little additional effort might be required of either the parties or the judges in Supreme Court cases in which jurisdictional papers already must be prepared, the Commission's proposal 
The question remains what to do about overload problems in the courts of appeals. It may be that the creation of an administrative court is the least of evils. We hope not. It would be a pity to create an inferior system of judicial review because no better way can be found to restore to the federal courts the time required to do their job. ${ }^{365}$

would impose a new certiorari-like practice upon the courts of appeals. Moreover, the parameters governing that practice, except in cases of actual conflict, are at this stage vague enough to give rise to real problems. A broad view of when "an immediate authoritative determination" would be "in the public interest" might strip the regional courts of all but routine cases, eliminate the benefits of diverse judicial views-a problem adverted to hut not resolved by Senator Hruska-and either swamp the National Court or necessitate wholesale and time-consuming retransfers. Surely no such interpretation is intended, but we must confess an inability to perceive even a subjective criterion short of this that lends meaningful content to the proposed test for transferability. At the other extreme, regional courts jealous of their interesting cases might frustrate the purpose of this scheme by excessive hostility to transfers. At this problem stage, therefore, we have doubts as to the administrability of the proposal. Perhaps when the Commission fleshes out the bare bones of its ideas, it can satisfy those reservations. Perhaps further reflection will convince us that the difficulties noted above are not as scrious as we now believe them to be. Our tentative view, however, is that the problem of unsettled national law would have to be considerable indeed to justify the adoption of the Commission's plan.

365. Sec Hines \& Nathanson, supra note 309 , at C-7, C-20. 